\title{
A study of the possibilities and effect of assistive robots in the intramural elderly healthcare
}

Citation for published version (APA):

Bemelmans, R. F. J. (2015). A study of the possibilities and effect of assistive robots in the intramural elderly healthcare. [Doctoral Thesis, Maastricht University]. Maastricht University. https://doi.org/10.26481/dis.20151111rb

Document status and date:

Published: 01/01/2015

DOI:

10.26481/dis.20151111rb

Document Version:

Publisher's PDF, also known as Version of record

\section{Please check the document version of this publication:}

- A submitted manuscript is the version of the article upon submission and before peer-review. There can be important differences between the submitted version and the official published version of record.

People interested in the research are advised to contact the author for the final version of the publication, or visit the DOI to the publisher's website.

- The final author version and the galley proof are versions of the publication after peer review.

- The final published version features the final layout of the paper including the volume, issue and page numbers.

Link to publication

\footnotetext{
General rights rights.

- You may freely distribute the URL identifying the publication in the public portal. please follow below link for the End User Agreement:

www.umlib.nl/taverne-license

Take down policy

If you believe that this document breaches copyright please contact us at:

repository@maastrichtuniversity.nl

providing details and we will investigate your claim.
}

Copyright and moral rights for the publications made accessible in the public portal are retained by the authors and/or other copyright owners and it is a condition of accessing publications that users recognise and abide by the legal requirements associated with these

- Users may download and print one copy of any publication from the public portal for the purpose of private study or research.

- You may not further distribute the material or use it for any profit-making activity or commercial gain

If the publication is distributed under the terms of Article $25 \mathrm{fa}$ of the Dutch Copyright Act, indicated by the "Taverne" license above, 


\section{A study of the possibilities and effect of assistive robots in the intramural elderly healthcare}

Roger Bemelmans 
Grafic support:

Context4You

Photography:

Arnaud Nilwik

Printing:

B-Mediagroep

ISBN 978-90-9029362-2

Copyright (C) Roger Bemelmans, Maastricht 2015 


\section{A study of the possibilities and effect of assistive robots in the intramural elderly healthcare}

\section{PROEFSCHRIFT}

ter verkrijging van de graad van doctor aan de Universiteit Maastricht, op gezag van de Rector Magnificus, Prof. dr. L.L.G. Soete, volgens het besluit van het College van Decanen,

in het openbaar te verdedigen op woensdag 11 november 2015 om 16:00 uur

door

Roger Franciscus Joseph Bemelmans 


\section{Promotores}

Prof. dr. L.P. de Witte

Prof. dr. ir. P.P. Jonker (Technische Universiteit Delft)

\section{Copromotor}

Dr. G.J. Gelderblom (O 1963-@ 2014)

\section{Beoordelingscommissie}

Prof. dr. J.M.G.A. Schols (voorzitter)

Prof. dr. K. Dautenhahn (University of Hertfordshire, Engeland)

Dr. S van Hooren (Zuyd Hogeschool)

Prof. dr. F.R.J. Verhey

Prof. dr. G. Weiss 


\section{Contents}

Chapter 1 General introduction 3

Chapter 2 Socially assistive robots in elderly care: 11

A systematic review into effects and effectiveness

Chapter 3 State of the art in socially assistive robots for elderly car 33

$\begin{array}{lll}\text { Chapter } 4 & \text { Development of robot interventions } & 49\end{array}$

for intramural psychogeriatric care

Chapter 5 How to use robot interventions in intramural 67

psychogeriatric care: A feasibility study

Chapter 6 Effectiveness of robot Paro in intramural psychogeriatric care: A multi-center quasi-experimental study

$\begin{array}{lll}\text { Chapter } 7 & \text { General discussion } & 97\end{array}$

$\begin{array}{lll}\text { Chapter } 8 \text { Valorisation } & 111\end{array}$

$\begin{array}{ll}\text { Summary } & 117\end{array}$

$\begin{array}{ll}\text { Samenvatting } & 121\end{array}$

$\begin{array}{ll}\text { Dankwoord } & 125\end{array}$

$\begin{array}{ll}\text { About the author } & 129\end{array}$

$\begin{array}{ll}\text { List of publications } & 131\end{array}$ 



\section{General introduction}





\section{Introduction}

The ongoing development of technology provides a vast potential of opportunities for the provision of care in industrialized countries. On the basis of technologies such as IT and robotics, applications are feasible facilitating elements of independence for elderly clients with disabilities or chronic conditions who are now dependent on regular human support. Moreover, professionals and informal caregivers could also be supported in their work by innovative technology. The need for autonomy and the limited availability of care providers make the quest for technological support relevant. Moreover, the possible increase of care quality plays a role.

In Western Europe's near future the relative population of elderly will increase due to ageing, caused by the postwar baby boom and an increase of life expectancy. This will result in an unbalanced growth between caregivers and caretakers, putting pressure on the quality of our health care system. This thesis is about the potential of robot technology for elderly care, more specifically Socially Assistive Robots (SAR). A robot is able to process data in a very fast and objective manner, does not become sick or tired, has no stress and carries out its tasks with a high degree of exactitude. By the increasing technological developments the costs of this technology decreases and people become more and more familiar with technological appliances. Reduction of the costs in care surroundings can be realized because robots can take over tasks of trained staff. Moreover, patients are less dependent on (human) care providers, which can reinforce the feeling of self-control and autonomy. Research is necessary to retrieve the care questions that can be answered with available and appropriate robot technologies.

\section{Problem definition}

We are all getting older, and with it ailments both physically and cognitively increase. Technology and technical tools can play an important supportive role and give older people more self-control and control over their actions.

People are becoming more dependent on care and support and may eventually no longer operate independently. They are often, after a period of time in the rising of the symptoms, by necessity admitted in a care institution. Despite the fact that 
enthusiastic caregivers with passion for their work, work daily to guide and assist the residents in order to safeguard the quality of life, these caregivers also run up against the limits of their ability. There are not always enough caregivers available at times when residents need it. This need may be focused on personal attention, meaningful activities, countering loneliness or the provision of daily care. Again, technology can play a supporting role, and both support the caregivers in their work and offer the residents more quality of life.

For various reasons technology, in particular robot technology, more and more finds its way to health care or at least becomes an interesting component within health care provision. Approximately half of the care dependence of the elderly must be attributed to dementia ${ }^{1}$. According to the Dutch Health Council, $53 \%$ of the nursing home residents and $25 \%$ of the care home residents in the Netherlands have been diagnosed with dementia. No pill or therapy which can heal or prevent dementia is available yet. For this reason the relevance of interventions and symptom suppression, which enhance the well-being of the patient and the people around them, is high. These interventions should, among others, aim at:

- conservation of autonomy, individual character and dignity;

- strengthening of communication possibilities and conservation of social contact;

- strengthening the feeling of security;

- exploitation of the possibilities of enjoying.

Person-specific approaches are scientifically reviewed, more often the last years on their effectiveness, with positive results ${ }^{2}$. By the increasing technological developments, particularly in the field of robot technology, more and more possibilities arise at the aforementioned interventions.

The iCat, Paro, Pleo and AiBO are examples of robot technology which have been developed in this area. Besides the fact that people take pleasure in having a pet, without the responsibility for a living animal in a care home, these pet-like robots can monitor by means of sensors and signal for example in case of danger. Also the feeling of autonomy is reinforced because people depend less on human support. With necessary prudence one can make an analogy with the role of a guide dog for visually impaired people. On a limited scale there has been done research in the field of robot technology for the elderly. Libin ${ }^{3}$ has compared a robot cat with a plush toy cat as 
an intervention for elderly with dementia. Also a study with the Paro, a seal robot, into the improvement of communication and interaction in a group has been done ${ }^{4}$. Socially assistive robotics focuses on providing assistance through social rather than physical interaction between the robot and the human user ${ }^{5}$. The robot's physical form is particularly important to consider in SAR work because it facilitates the human tendency to engage with and ascribe social characteristics to even relatively simple robotic forms ${ }^{6}$. An effective socially assistive robot must understand and interact with its environment, exhibit social behavior, focus its attention and communication on the user, sustain engagement with the user, and achieve specific assistive goals. The robot can do all of this through social rather than physical interaction, and in a way that is safe, ethical and effective for the potentially vulnerable user ${ }^{7}$. SAR has been defined by Feil-Seifer ${ }^{5}$ as having non-physical contact interaction, in this thesis we do not follow this definition strictly. Physical contact is not a primary objective for SAR, it can however be a way for the user to give more meaning to the social interaction. We regard the absence of physical contact therefore not as a necessary condition for SAR. SAR has the potential to enhance human quality of life for large user populations, including the elderly. Even as socially assistive robotic technology is still in its early stages of development, the next decade promises systems that will be used in hospitals, schools, and homes in therapeutic programs that monitor, encourage, and assist their users ${ }^{8}$.

\section{Relevance}

Broad and fast setting-up of innovations is important so that all citizens can profit from better quality and patient well-being in prevention and health care. Fast developments in new technologies and the convergence of it, can offer unique chances ${ }^{9}$. Insight into the care wishes, coupled to available assistive robot technologies will lead to the identification of high potential applications. An effectiveness study of these applications will be of major interest to caretakers, care providers, care financiers but also to the product developers.

The five most occurring and complex health problems, also known as the Geriatric Giants, are: forgetfulness, dementia, hearing problems and visual impairments, incontinence and mobility impairments ${ }^{10}$. Dementia is one of the most serious problems. 


\section{CHAPTER 1}

The Dutch Health Council has calculated that in the year 2000 approximately 170,000 people had dementia, a ratio of 1 on 93 people. In 2010 that number ran up to 207,000 , a ratio of 1 on 81 . That increase continues so that in the year 2020 there will be almost 246,000, a ratio of 1 on 71 , people with dementia and in the year 2030 almost 355,000 . In the year 2050 , according to the expectations, 412,000 people above 65 years will have dementia, a ratio of 1 on 44 people. More and more people will be confronted, in their surroundings, with someone with dementia. The costs in 2005 for dementia amounted to 3.2 billion euro. This is $4.7 \%$ of the total costs in the Dutch health care in 2005. Within the group of mental impairments $22.8 \%$ of the costs are made for the care for people with dementia. Dementia is for men and women together, after intellectual disability, the most expensive disorder ${ }^{11}$.

Reduction of the costs in care surroundings can be realized because robots can take over tasks of trained staff. It is not sufficient to examine the effect the robots will have in a laboratory setting or in a conditioned field study. The robot must have such a degree of effectiveness, both functionally and in use, that the patients are willing to use the robot in daily life. If the robot technology is reliable accepted and performs to satisfaction this research can provide a significant contribution in the improvement of the total well-being of patients, with an increase of care quality and possibly a reduction of the costs.

\section{Objective}

The thesis has two main aims.

1. Identifying high potential applications of assistive robot technology in intramural psychogeriatric care.

2. Examining the effectiveness of the assistive robot technology in the selected applications.

The results not only show the appropriate robot technology, but also how to use it and the effectiveness of it. With these results, based on the proven effectiveness, the robot technology can be made ready for the market. The results must be available for care providers, care takers, government, care financiers and product developers. 
This thesis describes roughly three phases. In the first phase (Chapters 2-4) the care questions, available robot technology and published effects of robot interventions are gathered, to identify a set of high potential applications. In the second phase (Chapter 5) a pilot study with a relative small set of robots, objectives and elderly is carried out to validate the insights from phase 1 and to get some practical experience in this field on how to introduce and apply a robot in the care environment and how to measure outcomes or effects. In the third phase (Chapter 6) large scale field studies are carried out to evaluate the effect of the developed assistive robot technology in the context of the selected applications. In the last chapter, the main findings of the research presented in this thesis will be discussed and a reflection on some methodological and theoretical issues will be provided. Based on the conclusions that can be drawn from this thesis, implications for practice and suggestions for future research will be presented.

\section{References}

1. Gezondheidsraad. Dementie. Gezondheidsraad, Den Haag. 2002 (publicatie nr 2002/04).

2. de Lange J. Omgaan met dementie: het effect van geïntegreerde belevingsgerichte zorg op adaptatie en coping van mensen met dementie in verpleeghuizen; een kwalitatief onderzoek binnen een gerandomiseerd experiment, Erasmus MC: University Medical Center Rotterdam; 2004 .

3. Libin A, Cohen-Mansfield J. Therapeutic robocat for nursing home residents with dementia: preliminary inquiry. American journal of Alzheimer's disease and other dementias. 2004(2):111-116.

4. Kidd CD, Taggart W, Turkle S. A sociable robot to encourage social interaction among the elderly. Paper presented at: Robotics and Automation, 2006. ICRA 2006. Proceedings IEEE International Conference on; 15-19 May 2006.

5. Feil-Seifer D, Mataric MJ. Defining socially assistive robotics. Paper presented at: Rehabilitation Robotics, 2005. ICORR 2005. 9th International Conference on 2005.

6. Okamura AM, Mataric, x, J. M, Christensen HI. Medical and Health-Care Robotics. Robotics \& Automation Magazine, IEEE. 2010;17(3):26-37.

7. Christensen $\mathrm{H}$, Batzinger T, Bekris $\mathrm{K}$, et al. A roadmap for us robotics: From internet to robotics. Computing Community Consortium and Computing Research Assoc. 2009.

8. Tapus A, Mataric MJ, Scasselati B. Socially assistive robotics [Grand Challenges of Robotics]. Robotics \& Automation Magazine, IEEE. 2007;14(1):35-42. 


\section{CHAPTER 1}

9. Klink A, Bussemaker J. Innovatie in preventie en zorg. Ministerie van Volksgezondheid, Welzijn en Sport. 2008.

10. Ministerie V. Ouderenbeleid in het perspectief van de vergrijzing. Den Haag, Ministerie van Volksgezondheid, Welzijn en Sport. 2005.

11. Poos M, Smit J, Groen J, Kommer G, Slobbe L. Kosten van ziekten in Nederland 2005: zorg voor euro's-8. RIVM rapport 270751019. 2008. 


\section{Socially assistive robots in elderly care: A systematic review into effects and effectiveness}

This chapter was published as:

Bemelmans R, Gelderblom G), Jonker P, de Witte L. Socially assistive robots in elderly care: A systematic review into effects and effectiveness. Jamda: Journal of the American Medical Directors Association 2012;13:114-120. DOI: 10.1016/j.jamda.2010.10.002. 


\section{CHAPTER 2}

\section{Abstract}

The ongoing development of robotics on the one hand and on the other hand the foreseen relative growth in number of elderly, suffering from dementia, raises the question which contribution robotics could have to rationalize and maintain, or even improve the quality of care.

The objective of this review is to assess the published effects and effectiveness of robot interventions aiming at social assistance in elderly care.

We searched, using Medical Subject Headings (MeSH) terms and free words, in the CINAHL, MEDLINE, Cochrane, BIOMED, PUBMED, PsycINFO and EMBASE databases. Also the IEEE Digital Library was searched. No limitations were applied for the date of publication. Only papers written in English were taken into account. Collected publications went through a selection process. In the first step publications were collected, from major databases using a search query. In the second step three reviewers independently selected publications on their title, using predefined selection criteria. In the third step publications were judged based on their abstracts by the same reviewers, using the same selection criteria. In the fourth step one reviewer made the final selection of publications based on complete content.

Finally 41 publications were included in the review, describing 17 studies involving 4 robot systems. Most studies reported positive effects of companion type robots on (socio) psychological (e.g. mood, loneliness and social connections and communication) and physiological (e.g. stress reduction) parameters. The methodological quality of the studies was, mostly, low.

Although positive effects are reported, the scientific value of the evidence is limited. The positive results described, however, prompt further effectiveness research in this field. 


\section{Introduction}

The ongoing development of technology, specifically robots, against the background of a decreasing number of care personnel raises the question what the potential contribution of robotics could be in rationalizing and maintaining, or even improving the quality of elderly care. Robots can contribute to health care support in terms of capacity, quality (performing very accurately and task specific), finance (support or even take over tasks of trained personnel) and experience (e.g. increase feeling of autonomy and self management).

In Western Europe's near future the relative population of elderly people will increase due to ageing, caused by both the postwar baby boom and an increase of the life expectancy. By 2050, the working-age population of Europe will be down to 364 million, a 25 per cent reduction compared to the 1995 level. On the other hand, the population aged 65 or older will rise steadily, from 101 million in 1995 to nearly 173 million in 2050. As a result, the potential support ratio (the number of persons aged 15-64 years per one older person aged 65 years or older) will be severely reduced, from 4.8 in 1995 to 2.1 in $2050^{1}$. This will result in an unbalanced growth of care givers and care takers, putting pressure on the quality of our health care systems.

The idea of robotics playing a role in health care was launched some decades ago and has mainly been developed for physical training in rehabilitation as well as personal assistance for ADL tasks ${ }^{2}$. Robotic applications supporting social behavior are a more recent development ${ }^{3}$. So far systems have been developed supporting child's play (e.g. ${ }^{4}$ ) and care for elderly with dementia (e.g. ${ }^{5}$ ). However, the uptake of these systems in care practice has been limited. One of the reasons is that there appears to be a mismatch between what is technically developed and the perceived needs within care environments ${ }^{3}$.

The term socially interactive robotics (SIR) was first used by Fong et al. ${ }^{6}$ to describe robots whose main task was to provide some form of interaction. The term SIR was introduced to distinguish these robots from other robots that involve "conventional" human robot interaction, such as in tele-operation scenarios. Feil-Seifer et al. ${ }^{7}$ define socially assistive robotics (SAR) as the intersection of assistive 
robotics (AR) and socially interactive robotics (SIR). Assistive robotics itself has not been formally defined or surveyed. An adequate definition of an assistive robot is one that gives aid or support to a human user. Research into assistive robotics includes rehabilitation robots, wheelchair robots and other mobility aides, companion robots, manipulator arms for the physically disabled, and educational robots. In $S I R$, the robot's goal is to develop close and effective interactions with a human for the sake of interaction itself. In contrast, in SAR, these systems are not designed to help the human being performing work tasks or saving time in routine activities, but to give assistance through social interaction to achieve progress in e.g. convalescence, rehabilitation and learning. As such, SAR is a subsection of SIR.

The purpose of this paper was to report on the published effects and effectiveness of SAR for elderly people in everyday life.

\section{Methods}

In September 2009 a systematic literature review was carried out, based on the Cochrane Handbook ${ }^{8}$. The CINAHL, MEDLINE, Cochrane, BIOMED, PUBMED, PsycINFO and EMBASE databases and the IEEE Digital Library (Xplore) were systematically searched for publications (i.e. journal articles, extended abstracts and conference proceedings) about socially assistive robotics applied in elderly care. No limitations were applied for date of publication. Only papers written in English were taken into account. Selected publications then went through a selection process involving three reviewers. The selection process was based on title, abstract and complete content, in order to obtain a final set of publications to be included in the review.

The objective of the search, in short, was to find measured effects and consequences of socially assistive robots used in elderly care. The search query was divided into three logical conjunctive components. These components represent, with several free words and Medical Subject Headings (MeSH) terms, the objective (measured effects and effectiveness), the subject (elderly) and the means (robots).

To limit the chance of excluding relevant publications, the search in the first step (i.e. the database search) was based solely on subject and means, so the objec- 
tive (measured effects) was not included. The free words for the subject (or their database specific thesaurus equivalent) were "elder*", "age*", "old people", "senior*" and "dementia" and their associated MeSH terms (or their database specific equivalent) were "Housing for the Elderly", "Aged", "Health Services for the Aged", "Residential Facilities" and "Dementia" (including their subheadings). The free words for the means (or their database specific Thesaurus equivalent) were "robot*" and "assis* technol*" and their associated MeSH terms (or their database specific equivalent) were "Robotics", "Self-Help Devices" and "Mobile Health Units" (including their subheadings). By using the asterisk (*) the term becomes a prefix. So 'assis*' represents among others 'assisting' and 'assistive'.

In the steps mentioned below the reviewers (i.e. authors RB, GG and LW) independently judged the relevance of the publications, on a 3-point scale (i.e. $\mathrm{O}=$ not relevant, $1=$ relevant, $2=$ very relevant). The reviewers were equally instructed to independently judge the relevance of the publications based on the criteria that the publications should describe measured effects and effectiveness of robot interventions aiming at social assistance in elderly care. To limit the change of excluding relevant publications a low total score was used as selection criterion, i.e. all publications with a total score of at least 2 points were selected.

In a second step the three reviewers individually selected relevant publications, based on their title, for the third step. In a third step the publications were individually judged by the three reviewers based on their abstracts. In a fourth step the publications were read in full and judged by one reviewer (i.e. author RB) in order to obtain the final set of publications for the review. In addition, again to limit the change of missing relevant publications, publications were selected through Internet search (Google Scholar), and by hand from conference proceedings (HRI, ICORR, ICRA, ROMAN) and from reference lists of selected publications.

Given the aim of this review, to investigate what is published about the effects of SAR in elderly care, no studies were excluded on the basis of quality criteria. A formal assessment of the methodological quality of the papers found appeared to be of little value, given the small number of studies reported, the very basic and descriptive character of most studies and the fact that most papers found are conference proceedings. 


\section{CHAPTER 2}

\section{Results}

In the first step 2891 publications were found. In the second step 123 titles were selected as relevant, of which 11 had a review score of $\mathrm{O}+\mathrm{O}+2=2$ (i.e. two reviewers scored $\mathrm{o}$ and one reviewer scored 2 ). In the third step 37 publications were selected, based on their abstracts, of which 3 had a review score of $\mathrm{O}+\mathrm{O}+2=2$. Table 1 shows the weighted Cohen's kappa coefficient for the inter-rater agreement between the three reviewers. Reviewer RB had all along the line a more positive score compared to the other reviewers.

In addition, 30 publications were selected via the free Internet search and from conference proceedings (having no overlap with the publications selected in step 3 ). Finally, 41 publications, of which 30 from step three, were included in the review, see figure 1.

The 41 included publications report on 17 studies involving 4 robot systems and 1 undefined robot. There were 8 journal publications, 2 electronic publications and 31 conference proceedings. Categorizing the publications based on the robot system there were 3 publications on the robot Bandit describing 1 study (by Tapus et al.), 4 publications on the AIBO robot describing 4 studies, 30 publications on the Paro robot describing 8 studies (in majority by Wada, Shibata et al.), 2 publications describing 2 studies about the robot NeCoRo (by Libin et al.), 1 publication with an unspecified robot and 1 publication with an overview of several robots. Table 2 presents an overview of the characteristics of the aforementioned robots. Table 3 presents the characteristics of the included studies.

In the following paragraphs the studies are briefly described per robot system.

Table 1. Reviewers Inter-Rater Agreement

\begin{tabular}{cccc}
\hline \multicolumn{4}{c}{ weighted Cohen's kappa coefficient } \\
\hline RB GG & RB LW & LW GG \\
step 2 & 0.47 & 0.51 & 0.57 \\
step 3 & 0.52 & 0.55 & 0.69 \\
\hline
\end{tabular}




\section{Step 1.}

2891 publications were selected from major databases

(i.e. CINAHL, MEDLINE, Cochrane, BIOMED,

PUBMED, PsycINFO, EMBASE and IEEE).

Criteria: elderly and robot.

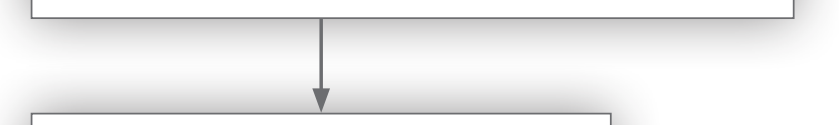

\section{Step 2.}

123 publications were selected, based on title, by three reviewers.

Criteria: elderly, robot and effects.

\section{Step 3.}

37 publications were selected, based on abstract, by three reviewers.

Criteria: elderly, robot and effects.

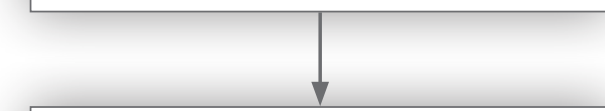

\section{Step 4 .}

41 publications remained after reading full text and adding relevant publications from the reference lists. ROMAN).

17 studies are reported in the 41 publications, involving 4 robot systems and 1 undefined robot.

Figure 1. Schematic Overview of Selection Process with Search Results 
Table 2. Socially Assistive Robots used in Reviewed Studies

\section{Robot Description}

NeCoRo A cat-like robot with synthetic fur, introduces communication in the form of playful, natural exchanges like between a person and a cat. Via internal sensors of touch, sound, sight and orientation human actions and its environment can be perceived. Behavior is generated based on internal feelings, using 15 actuators inside the body.

Bandit A humanoid torso mounted on a mobile platform. The mobile platform is equipped with a speaker, color camera and an eye-safe laser range finder. The torso includes: two 6 Degrees Of Freedom (DOF) arms, two 1 DOF gripping hands, one 2 DOF pan/tilt neck, one 2 DOF pan/tilt waist, one 1 DOF expressive eyebrows and a 3 DOF expressive mouth. All actuators are servos allowing for gradual control of the physical and facial expressions.

\section{Picture}
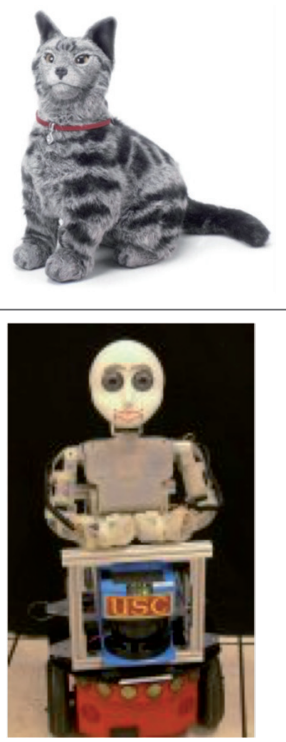

AIBO A dog-like robot that can see, hear and understand commands. It has the ability to learn, to adapt to its environment and to express emotion. It uses its Illume-Face to communicate when it detects toys, someone's hand, voice commands or face and voice. Each expression appears as an animated pattern on the Illume- Face display, created by LEDs that light up or fade out to varying degrees.

Paro A seal-like robot with five types of sensors: tactile, light, audio, temperature and posture, with which it can perceive people and its environment. With the light sensor it can distinguish between light and dark. It feels being stroked or beaten by its tactile sensors, or being held by the posture sensor. It can recognize the direction of voice and words such as its name and greetings with its audio sensor. 
Table 3: Characteristics of Included Studies

\begin{tabular}{|c|c|c|c|c|c|c|}
\hline Robot & Intervention & Duration & Ref & Indicators & Participants & Outcomes \\
\hline \multirow[t]{6}{*}{ Paro } & $\begin{array}{l}\text { Free group } \\
\text { interaction. }\end{array}$ & $\begin{array}{l}20 \mathrm{~min} / \mathrm{d} \\
3 \mathrm{~d} / \mathrm{wk} \\
5 \mathrm{wk}\end{array}$ & $15-17$ & $\begin{array}{l}\text { POMS, } \\
\text { nursing staff } \\
\text { comments. }\end{array}$ & $\begin{array}{l}\text { Japan, day } \\
\text { service center. } \\
26 \text { females, } \\
73-93 \text { yr, } \\
\text { dementia. }\end{array}$ & $\begin{array}{l}\text { Positive psychologi- } \\
\text { cal social effects. }\end{array}$ \\
\hline & $\begin{array}{l}\text { Between-sub- } \\
\text { ject compar- } \\
\text { ing regular } \\
\text { andplacebo } \\
\text { Paro. Free } \\
\text { group inter- } \\
\text { action. }\end{array}$ & $\begin{array}{l}1 \mathrm{hr} / \mathrm{d} \\
4 \mathrm{~d} / \mathrm{wk} \\
1 \mathrm{mo}\end{array}$ & $18-25$ & $\begin{array}{l}\text { Face scale, } \\
\text { POMS, } \\
\text { nursing staff } \\
\text { comments, } \\
\text { urine tests, } \\
\text { burn- } \\
\text { out-scale } \\
\text { for nursing } \\
\text { staff. }\end{array}$ & $\begin{array}{l}\text { Japan, nurs- } \\
\text { ing home. } 23 \\
\text { participants in } \\
2 \text { groups, only } \\
\text { light demen- } \\
\text { tia. }\end{array}$ & $\begin{array}{l}\text { Depression de- } \\
\text { creased and mood } \\
\text { improved similar } \\
\text { in both groups. } \\
\text { Positive influence } \\
\text { in reducing nursing } \\
\text { staff stress. }\end{array}$ \\
\hline & $\begin{array}{l}\text { Free group } \\
\text { interaction. }\end{array}$ & $\begin{array}{l}1 \mathrm{hr} / \mathrm{d}, 2 \\
\mathrm{~d} / \mathrm{wk}, 1 \mathrm{yr} .\end{array}$ & $\begin{array}{l}9,26- \\
31\end{array}$ & $\begin{array}{l}\text { Face scale, } \\
\text { GDS, } \\
\text { nursing staff } \\
\text { comments. }\end{array}$ & $\begin{array}{l}\text { Japan, nurs- } \\
\text { ing home. } \\
14 \text { females, } \\
\text { dementia. }\end{array}$ & $\begin{array}{l}\text { Encouraged com- } \\
\text { munication, more } \\
\text { social interaction, } \\
\text { stress reduction. } \\
\text { Improved moods } \\
\text { and depression. }\end{array}$ \\
\hline & $\begin{array}{l}\text { Free interac- } \\
\text { tion, before } \\
\text { and after } \\
\text { study. }\end{array}$ & $20 \mathrm{~min}$. & 32 & $\begin{array}{l}21 \text { channel } \\
\text { EEG. }\end{array}$ & $\begin{array}{l}\text { Japan, care } \\
\text { house. } 14 \\
\text { participants, } \\
\text { dementia. }\end{array}$ & $\begin{array}{l}7 \text { participants } \\
\text { showed effective } \\
\text { improvement of } \\
\text { cortical neuron } \\
\text { activity. }\end{array}$ \\
\hline & $\begin{array}{l}\text { Free interac- } \\
\text { tion. }\end{array}$ & $\begin{array}{l}9 \mathrm{hr} / \mathrm{d} \text {, } \\
2 \mathrm{mo} \text {. }\end{array}$ & $\begin{array}{l}10, \\
33-38\end{array}$ & $\begin{array}{l}\text { Observa- } \\
\text { tions, urine } \\
\text { tests, inter- } \\
\text { views. }\end{array}$ & $\begin{array}{l}\text { Japan, care } \\
\text { house. } 12 \\
\text { participants, } 1 \\
\text { male, demen- } \\
\text { tia. }\end{array}$ & $\begin{array}{l}\text { Encouraged com- } \\
\text { munication, more } \\
\text { social interaction. }\end{array}$ \\
\hline & $\begin{array}{l}\text { Spontaneous } \\
\text { and only } \\
\text { partially } \\
\text { structured } \\
\text { interaction. }\end{array}$ & $\begin{array}{l}20 \mathrm{~min} / \mathrm{d} \\
2 \mathrm{~d} / \mathrm{wk} \\
1 \mathrm{mo}\end{array}$ & 39 & $\begin{array}{l}\text { Speech and } \\
\text { behavior } \\
\text { observation. }\end{array}$ & $\begin{array}{l}\text { Italy, nurs- } \\
\text { ing home. } 5 \\
\text { participants, } 1 \\
\text { male, } 56-83 \text { yr, } \\
\text { mild to severe } \\
\text { dementia } \\
\text { (MMSE). }\end{array}$ & $\begin{array}{l}\text { All showed ten- } \\
\text { dency to attribute } \\
\text { intentional states } \\
\text { to robot. Significant } \\
\text { interaction depends } \\
\text { mostly on specific } \\
\text { context of interac- } \\
\text { tion, not on physical } \\
\text { and functional } \\
\text { characteristics. }\end{array}$ \\
\hline
\end{tabular}




\section{Robot Intervention Duration Ref Indicators Participants Outcomes}

\begin{tabular}{|c|c|c|c|c|c|}
\hline $\begin{array}{l}\text { Within-sub- } \\
\text { ject ran- } \\
\text { domized } \\
\text { comparison } \\
\text { with placebo } \\
\text { Paro. Free } \\
\text { interaction } \\
\text { in small } \\
\text { groups, with } \\
\text { caregiver. }\end{array}$ & $\begin{array}{l}20 \\
\min / 2 \mathrm{wk}, \\
4 \mathrm{mo} .\end{array}$ & 40,41 & $\begin{array}{l}\text { Video ob- } \\
\text { servations, } \\
\text { question- } \\
\text { naires. }\end{array}$ & $\begin{array}{l}\text { United States, } \\
\text { nursing } \\
\text { home. } 16 \\
\text { high-function- } \\
\text { ing partici- } \\
\text { pants. }\end{array}$ & $\begin{array}{l}\text { Placebo Paro is less } \\
\text { interesting. Increase } \\
\text { in social interac- } \\
\text { tions, even more in } \\
\text { presence of caregiv- } \\
\text { ers. Pleasing, feel- } \\
\text { good and evocative } \\
\text { experiences. Paro is } \\
\text { heavy, sometimes } \\
\text { scary (non-domes- } \\
\text { ticated animal), } \\
\text { with mismatch in } \\
\text { expectations (not } \\
\text { waterproof). }\end{array}$ \\
\hline
\end{tabular}

Field trial. 9 mo. $\quad 42$ Observing Italy, nurs- Relation with Paro Therapists interactions ing home. 9 becomes privileged autonomous- (filming). participants, space to externalize ly choose dementia. internal emotionwhen and where to present Paro. al states. Paro activates triadic exchanges (social Mediator). Catalyser of emotions is the key point of its therapeutic efficacy. Context of interactions is decisive in therapeutic context, not robot's ability.

\begin{tabular}{|c|c|c|c|c|c|c|}
\hline AIBO & $\begin{array}{l}\text { Before and } \\
\text { after study. } \\
\text { Stimulated } \\
\text { interaction. }\end{array}$ & $\begin{array}{l}30 \mathrm{~min} / \\
\mathrm{wk}, ? \mathrm{wk} .\end{array}$ & 43 & $\begin{array}{l}\text { N-Demen- } \\
\text { tia scale, } \\
\text { utterances } \\
\text { and MMSE- } \\
\text { scale. }\end{array}$ & $\begin{array}{l}\text { Japan, group } \\
\text { home. } \\
8 \text { participants, } \\
6 \text { females, } \\
68-89 \text { yr, se- } \\
\text { nile dementia. }\end{array}$ & $\begin{array}{l}\text { Slight increase, no } \\
\text { significant differ- } \\
\text { ences. }\end{array}$ \\
\hline & $\begin{array}{l}\text { Within-sub- } \\
\text { ject group } \\
\text { comparison } \\
\text { between } \\
\text { AIBO } \\
\text { undressed, } \\
\text { dressed and } \\
\text { a toy dog. }\end{array}$ & $4 \mathrm{~d}$ & 14 & $\begin{array}{l}\text { Frequency } \\
\text { of action to } \\
\text { robot. }\end{array}$ & $\begin{array}{l}\text { Japan, geri- } \\
\text { atric health } \\
\text { care facility. } 13 \\
\text { participants, } 1 \\
\text { male, average } \\
84 \text { yr, severe } \\
\text { dementia } \\
\text { (GBS). }\end{array}$ & $\begin{array}{l}\text { Both effectively } \\
\text { increased activity } \\
\text { during occupation- } \\
\text { al therapy (OT). } \\
\text { AIBO needed more } \\
\text { intervention by } \\
\text { OT's than toy dog. } \\
\text { Dressing AIBO } \\
\text { made no significant } \\
\text { difference. }\end{array}$ \\
\hline
\end{tabular}




\section{Robot Intervention Duration Ref Indicators Participants Outcomes}

\author{
Between-sub- $30 \mathrm{~min} / 13 \quad$ MLAPS, \\ ject RCT with wk, 8 wk. UCLA LS \\ living dog \\ and control \\ group. Free \\ interaction.
}

\author{
United States, High levels of \\ long-term attachment and de- \\ care facility. crease in loneliness \\ AIBO $(N=12)$, to both dogs. No \\ Control significant differ- \\ $(n=13)$, no ence between dogs. \\ psychiatric or Level of attachment \\ Alzheimers not correlated with \\ disease. decrease in loneli- \\ ness.
}

\begin{tabular}{|c|c|c|c|c|c|c|}
\hline & $\begin{array}{l}\text { Between-sub- } \\
\text { ject con- } \\
\text { trolled study. } \\
\text { Free interac- } \\
\text { tion. }\end{array}$ & $\begin{array}{l}1 \mathrm{hr} / \mathrm{d}, 4 \\
\mathrm{~d} / \mathrm{wk}, 7 \\
\text { wk. }\end{array}$ & 44 & $\begin{array}{l}\text { Scoring } \\
\text { activity, } \\
\text { AOK LS, } \\
\text { biochemi- } \\
\text { cal marker } \\
\text { (CgA). }\end{array}$ & $\begin{array}{l}\text { Japan, nurs- } \\
\text { ing home. } \\
5 \text { females, } \\
\text { wheelchaired, } \\
\text { good cogni- } \\
\text { tion. }\end{array}$ & $\begin{array}{l}\text { Loneliness signifi- } \\
\text { cantly reduced. } \\
\text { Activity significantly } \\
\text { increased, CgA } \\
\text { decreased. Health } \\
\text { related QOL im- } \\
\text { proved. }\end{array}$ \\
\hline \multirow[t]{2}{*}{ NeCoRo } & $\begin{array}{l}\text { Free interac- } \\
\text { tion. Before } \\
\text { and during } \\
\text { within-sub- } \\
\text { ject study. } \\
\text { Comparing } \\
\text { randomized } \\
\text { sessions with } \\
\text { robot and } \\
\text { plush toy cat. }\end{array}$ & $\begin{array}{l}2 * 10 \\
\min .\end{array}$ & 11 & $\begin{array}{l}\text { ABMI, } \\
\text { LMBS, } \\
\text { AAID. }\end{array}$ & $\begin{array}{l}\text { United States, } \\
\text { nursing } \\
\text { home. } 9 \\
\text { females, } 83-98 \\
\text { yr, moderate } \\
\text { to severe } \\
\text { dementia } \\
\text { (GDS). }\end{array}$ & $\begin{array}{l}\text { Similar results } \\
\text { for both cats. The } \\
\text { more impaired the } \\
\text { less interaction. } \\
\text { Physically disruptive } \\
\text { behavior and overall } \\
\text { agitation decreased } \\
\text { significantly. }\end{array}$ \\
\hline & $\begin{array}{l}\text { Cross-cul- } \\
\text { tural group } \\
\text { comparison. }\end{array}$ & $15 \mathrm{~min}$. & 45 & PRCIS & $\begin{array}{l}\text { United States, } \\
\text { Japan. } 32 \\
\text { participants, } \\
16 \text { Ameri- } \\
\text { cans and } 16 \\
\text { Japanese of } \\
\text { both genders } \\
\text { and two age } \\
\text { groups, 20-35 } \\
\text { yr and 65-79 } \\
\text { yr. }\end{array}$ & $\begin{array}{l}\text { Males more than } \\
\text { females and older } \\
\text { more than younger } \\
\text { liked robot. Past } \\
\text { experience with } \\
\text { technology does } \\
\text { not predict interest, } \\
\text { past experience } \\
\text { with with real pets } \\
\text { positively predicts } \\
\text { interest in robot. }\end{array}$ \\
\hline $\begin{array}{l}\text { My Real } \\
\text { Baby, } \\
\text { AlBO, } \\
\text { Paro }\end{array}$ & Overview. & & 46 & & United States. & $\begin{array}{l}\text { Possibility for sig- } \\
\text { nificant attachment. } \\
\text { Sometimes caring } \\
\text { for robot is psycho- } \\
\text { logical burden. }\end{array}$ \\
\hline
\end{tabular}




\begin{tabular}{|c|c|c|c|c|c|c|}
\hline Robot & Intervention & Duration & Ref & Indicators & Participants & Outcomes \\
\hline $\begin{array}{l}\text { Un- } \\
\text { known }\end{array}$ & $\begin{array}{l}\text { Intervention } \\
\text { comparison } \\
\text { between } \\
\text { active and } \\
\text { passive ther- } \\
\text { apist. }\end{array}$ & $?$ & 47 & $\begin{array}{l}\text { Frequency } \\
\text { of action to } \\
\text { robot. }\end{array}$ & $\begin{array}{l}\text { Japan, nurs- } \\
\text { ing home. } \\
5 \text { elderly, } \\
\text { considerable } \\
\text { dementia. }\end{array}$ & $\begin{array}{l}\text { Active therapist } \\
\text { prompts sponta- } \\
\text { neous reaction to } \\
\text { robot reaction. }\end{array}$ \\
\hline Bandit & $\begin{array}{l}\text { Supervised } \\
\text { instructed } \\
\text { music based } \\
\text { cognitive } \\
\text { game. Before } \\
\text { and after } \\
\text { within-sub- } \\
\text { ject study. } \\
\text { Comparing } \\
\text { randomized } \\
\text { sessions with } \\
\text { robot and } \\
\text { computer } \\
\text { screen agent. }\end{array}$ & $\begin{array}{l}20 \mathrm{~min} / \\
\mathrm{wk}, 8 \mathrm{mo} .\end{array}$ & $\begin{array}{l}12, \\
48, \\
49\end{array}$ & $\begin{array}{l}\text { User ques- } \\
\text { tionnaires. } \\
\text { SMMSE } \\
\text { score. Eval- } \\
\text { uating task } \\
\text { performance } \\
\text { and time on } \\
\text { task. }\end{array}$ & $\begin{array}{l}\text { United States, } \\
\text { care facility. } \\
3 \text { females, } \\
\text { mild to severe } \\
\text { dementia } \\
\text { (SMMSE). }\end{array}$ & $\begin{array}{l}\text { Task performance } \\
\text { improved, more } \\
\text { with robot than } \\
\text { screen agent. } \\
\text { Participants enjoyed } \\
\text { interacting with } \\
\text { robot and preferred } \\
\text { robot to screen } \\
\text { agent. Before and } \\
\text { after SMMSE score: } \\
24-26,16-17 \text { and } \\
9-9 .\end{array}$ \\
\hline
\end{tabular}

Table 3 Legend:

$\min =$ minute

$\mathrm{hr}=$ hour

$\mathrm{d}=$ day

$\mathrm{wk}=$ week

mo $=$ month

$\mathrm{yr}=$ year

AAID = Attention Attitude Intensity of manipulation and Duration of engagement

$\mathrm{ABMI}=$ Agitated Behaviors Mapping Instrument

AOK LS = Ando Osada and Kodama Loneliness Scale

$\mathrm{CCE}=$ Comparison Condition Experimental Design

$\mathrm{CgA}=$ Chromogranin A

$\mathrm{EEG}=$ Electro-Encephalogram

GBS $=$ Gottfries-Brance-Steen score

GDS $=$ Global Deterioration Sale

LMBS = Lawtons Modified Behavior Stream

MLAPS $=$ Modifed Lexington Attachment to Pets Scale

MMSE = Mini-Mental State Examination

POMS $=$ Profile of Mood States

PRCIS = Person Robot Complex Interactive Scale

$\mathrm{QOL}=$ Qualiy Of Life

$\mathrm{RCT}=$ Randomized Controlled Trial

SMMSE = Standorized MMSE

UCLA LS = University of California Los Angeles Loneliness Scale 


\section{Paro}

From the selected publications the majority involved the seal robot Paro used in what seem to be two typical studies.

In the first study (Wada et al., i.a. ${ }^{9}$ ) the seal robot was given to 14 elderly in a health service facility. A desk was prepared for the robots in the center of a table. The elderly persons interacted freely with the robot for about 1 hour per day, for 2 days per week over a period of 1 year. The results showed that interaction with Paro improved their moods and depression, encouraged their communication, decreased their stress level, and the effects showed up through one year.

In the second study (Wada et al., i.a. ${ }^{10}$ ) the experiment was conducted in a care home, 12 persons aged between 67 and 89 years participated. Caregivers activated Paro on a table in a public space at 8:30 and returned to their office until 18:00, for a period of 2 months. The residents could play with Paro whenever they wished during the time period. The results showed that Paro encouraged them to communicate with each other, strengthened their social ties, and brought them psychological improvements. Physiologically, urine tests showed a significant improvement in hormone values (e.g. from 0.18 17-KS-S/17-OHCS to 0.26 after 4 weeks), indicating improved reactions of the residents' vital organs.

Both studies, conducted by the developers of the robot, are limited by the relatively small sample size and the absence of a control group. The other 6 studies, of which 3 conducted by the developers, show similar results but also lack a control group, have small sample sizes or a short duration.

\section{NeCoRo}

One pilot study ${ }^{11}$ compared the benefits of the robotic cat and a plush toy cat in interventions for elderly persons with dementia. Both cats were covered with soft synthetic fur, the plush cat was lighter and softer than the robotic cat. The study consisted of two interactive sessions, one with the robotic cat and one with the plush cat, with a duration of 10 minutes each. Only one session per day was conducted for each participant, 9 female residents participated aged between 83 and 98 years. The sessions were presented in random order in an attempt to rule out 


\section{CHAPTER 2}

the potential novelty effects. Increase of pleasure was measured. The amount of physically disruptive behaviors and overall agitation decreased significantly when the participants interacted with the cats. No significant difference is reported in using either the plush cat or the robotic cat. The level of engagement seems strongly associated with the level of cognitive impairment, i.e. the more impaired the less interaction.

Although having a control group, this study was limited by its small sample size and short-term sessions. The second study had sessions with a short duration (i.e. $15 \mathrm{~min}$.) and focussed mainly on cross-cultural differences.

\section{Bandit}

The reported study ${ }^{12}$ focused on the possible role of a socially interactive robot as a tool for monitoring and encouraging cognitive activities, in comparison with a computer screen, of elderly suffering from dementia. The social therapist robot tries to provide customized cognitive stimulation by playing a music game, named Song Discovery, with the user. The study consisted of a 20 minute session per week for 8 months, with 3 participants. Each session involved supervised instructed music based cognitive games. The sessions, with a computer simulation and with the physical robot, were presented in random order in an attempt to rule out the potential novelty effects. Improvement was observed for all participants with respect to reaction time and incorrectness. The user's task improvement was proportional with their level of cognitive impairment. The participants enjoyed interacting with the robot and preferred the robot to the computer screen. Music seemed to stimulate the interest and responsiveness of the participants, also the ability of the participants to multitask (singing and pushing button at the same time) was reported.

The results are not conclusive because of the small number of participants used in the study.

\section{AIBO}

Several studies about the use of AIBO within elderly care have been carried out, including a Randomized Controlled Trial (RCT) ${ }^{13}$ in which the robot was compared 
with living dogs. In another study, the robot was compared to toy dogs ${ }^{14}$. In the RCT study a high level of attachment and a decrease in loneliness to both the living dog and the AIBO robot was reported, with no significant difference between both. The other studies indicate that robot-assisted activity was useful to reduce loneliness and improve activities and emotional state of elderly people with dementia. On the other hand, the absence of a soft skin and the limited response capability to touch stimuli was also reported ${ }^{14}$.

\section{Discussion}

The reported literature review identified only a very limited set of studies for which a wide search was required. The domain of socially assistive robotics and in particular the study of their effects in elderly care apparently has not been studied comprehensively and only very few academic publications were found. The studies that were found were mainly reported in conference proceedings, underlining the initial stage of the application of this type of robot system. In the reported studies a small set of robot systems were found to be used in elderly care. Only Paro is commercially available, AIBO and $\mathrm{NeCoRo}$ no longer are. The robot Bandit is still in development phase.

So far, the effects and effectiveness of SAR in elderly care has not been proven comprehensively. Most research is done in Japan (potential cultural differences), with a limited set of robots (mostly Paro and AIBO), and not yet clearly embedded in a care need driven intervention. Although obvious positive effects are reported, the scientific quality of the evidence is limited due to methodological limitations, e.g. small sample sets, short durations, no control group, no randomization. The studies found were mainly of an exploratory nature, underlining once more the initial stage of application within care. On the other hand, the exploratory nature also emphasizes the, important, pioneer work of the researchers and caregivers and caretakers involved in this relatively young field.

In general, relations between the type of outcomes aimed for, either related to support of care or support of independence, and the application of the robot system in care, are not well established. Within any health care system, care interventions are adopted because of their added value. The reported outcomes were only partly directly linked to desired outcomes, related to the desired added value. 
Nevertheless, it is acceptable to state that the ongoing development of socially assistive robotics seems to hold a potential of opportunities for the provision of care and enhancing quality of life. Particularly against the background of increasing ageing and limited availability of care providers, resulting in more people suffering from mental problems and psychological and social isolation. Multimodel robot interfacing convincingly mimics social interaction between a human and robot. Given this type of interaction, for such applications system robustness, reliability and intrinsic safety will be easier to achieve than for the more physical type of care robots. However, it is clear that further research in this area is needed to prove the addded value and economical soundness for care provision.

For the successful application of a robot system in elderly care the availability of a sound technical system by itself is not enough. The chances are high that the application of socially assistive robots without the context of an intervention will not exceed the level of an entertaining gadget. Interventions need to be defined describing the use of the robot specified for its target group and their environment, including instructions for care staff. Moreover, the expected added value must be clarified along with their, qualitative and quantitative, indicators and outcome measures.

Finally, the intended effects of the robot interventions must be demonstrated in Randomized Controlled Trials with large enough populations and duration. When the application of socially assistive robots is to benefit a wider user population, the interventions must also meet the need of (public) care financers in order for them to reimburse the application of the robot intervention within the healtcare system.

The reported outcomes so far, indicate effects on physiological and even more on socio-psychological level. The next step could be to identify the social psychological needs of care providers and care takers and then develop care interventions targeting these needs with available SAR's. Insight into these types of effects will most likeley also lead to a need for further development of technical requirements and behavioral properties of these systems in a care context. Also the possible legal and ethical questions need to be adressed when the potential effects of SAR in elderly become more clearly outlined. 


\section{Conclusion}

There seems to be a potential for the use of robot systems in elderly care. The generally positive effects reported prompt for further research into the effects and potential use of socially assistive robotics in elderly care.

Additional research is required to experimentally investigate the effects of interventions featuring socially assistive robotics within real elderly care settings. Albeit, the reported effects of the SAR systems do indicate positive results while negative or no results are hardly reported. The collected evidence so far should be seen as first steps in an emerging application domain for robotics. The reported shortcomings of the collected evidence should not be taken as grounds to discard the potential but rather as an incentive for further research.

\section{References}

1. World Population Ageing 2007: United Nations;2007.

2. Butter M, Boxtel Jv, Kalisingh S, et al. Robotics for Healthcare, State of the art report: TNO, commissioned by the European Commission, DG Information Society, 2007.

3. Butter M, Rensma A, Boxtel Jv, et al. Robotics for Healthcare, Final Report: TNO, commissioned by the European Commission, DG Information Society, 2008.

4. Iromec, Interactive Robotic Social Mediators as Companions, 2009; http://www.Jromec.org.

5. Wada K, Shibata T, Asada T, Musha T. Robot therapy for Prevention of Dementia at Home. Journal of Robotics and Mechatronics. 2007:691-697.

6. Fong T, Nourbakhsh I, Dautenhahn K. A Survey of Socially Interactive Robots. Robotics and Autonomous Systems. 2003;42:143-166.

7. Feil-Seifer D, Mataric MJ. Defining socially assistive robotics. Paper presented at: Rehabilitation Robotics, 2005. ICORR 2005. 9th International Conference on.

8. Higgens J, Green S. Cochrane Handbook for Systematic Reviews of Interventions. 5.0.1 ed: The Cochrane Collaboration, 2008.

9. Wada K, Shibata T, Saito T, et al. Psychological and Social Effects of One Year Robot Assisted Activity on Elderly People at a Health Service Facility for the Aged. Paper presented at: Robotics and Automation, 2005. ICRA 2005. Proceedings of the 2005 IEEE International Conference on. 
10. Wada K, Shibata T. Living with Seal Robots in a Care House - Evaluations of Social and Physiological Influences. Paper presented at: Intelligent Robots and Systems, 2006 IEEE/RS) International Conference on.

11. Libin A, Cohen-Mansfield J. Therapeutic robocat for nursing home residents with dementia: preliminary inquiry. American journal of Alzheimer's disease and other dementias. 2004(2):111-116.

12. Tapus $A$. The role of the physical embodiment of a music therapist robot for individuals with cognitive impairments: Longitudinal study. Paper presented at: Virtual Rehabilitation International Conference, 2009.

13. Banks MR, Willoughby LM, Banks WA. Animal-assisted therapy and loneliness in nursing homes: use of robotic versus living dogs. Journal of the American Medical Directors Association. $2008(3): 173-177$.

14. Tamura T, Yonemitsu S, Itoh A, et al. Is an Entertainment Robot Useful in the Care of Elderly People with Severe Dementia? Journals of Gerontology - Series A Biological Sciences and Medical Sciences. Jan 2004;59(1):83-85.

15. Wada K, Shibata T, Saito T, Tanie K. Analysis of factors that bring mental effects to elderly people in robot assisted activity. Paper presented at: Intelligent Robots and System, 2002. IEEE/RSJ International Conference on.

16. Wada K, Shibata T, Saito T, Tanie K. Effects of robot assisted activity for elderly people at day service center and analysis of its factors. Paper presented at: Intelligent Control and Automation, 2002. Proceedings of the 4 th World Congress on.

17. Wada K, Shibata T, Saito T, Tanie K. Robot assisted activity for elderly people and nurses at a day service center. Paper presented at: Robotics and Automation, 2002. Proceedings. ICRA 'O2. IEEE International Conference on.

18. Shibata T, Wada K, Saito T, Tanie K. Robotic Therapy at an Elderly Institution using a Therapeutic Robot. Annual Review of CyberTherapy and Telemedicine. 2004;2:125-136.

19. Kazuyoshi W, Shibata T, Saito T, Tanie K. Robot assisted activity to elderly at a health service facility for the aged. Paper presented at: Neural Engineering, 2003. Conference Proceedings. First International IEEE EMBS Conference on.

20. Saito T, Shibata T, Wada K, Tanie K. Relationship between interaction with the mental commit robot and change of stress reaction of the elderly. Paper presented at: Computational Intelligence in Robotics and Automation, 2003. Proceedings. 2003 IEEE International Symposium on.

21. Wada K, Shibata T, Saito T, Tanie K. Effects of robot assisted activity to elderly people who stay at a health service facility for the aged. Paper presented at: Intelligent Robots and Systems, 2003. (IROS 2003). Proceedings. 2003 IEEE/RSJ International Conference. 
22. Wada K, Shibata T, Saito T, Tanie K. Psychological and social effects of robot assisted activity to elderly people who stay at a health service facility for the aged. Paper presented at: Robotics and Automation, 2003. Proceedings. ICRA 'O3. IEEE International Conference on.

23. Wada K, Shibata T, Saito T, Tanie K. Psychological, physiological and social effects to elderly people by robot assisted activity at a health service facility for the aged. Paper presented at: Advanced Intelligent Mechatronics, 2003. AIM 2003. Proceedings. 2003 IEEE/ASME International Conference on.

24. Wada K, Shibata T, Saito T, Tanie K. Relationship between familiarity with mental commit robot and psychological effects to elderly people by robot assisted activity. Paper presented at: Computational Intelligence in Robotics and Automation, 2003. Proceedings. 2003 IEEE International Symposium on.

25. Wada K, Shibata T, Saito T, Tanie K. Effects of robot-assisted activity for elderly people and nurses at a day service center. Proceedings of the IEEE. 2004;92 (11):1780-1788.

26. Wada K, Shibata T, Saito T, Tanie K. Effects of three months robot assisted activity to depression of elderly people who stay at a health service facility for the aged. Paper presented at: SICE 2004 Annual Conference, 2004.

27. Wada K, Shibata T, Saito T, Tanie K. Psychological and social effects in long-term experiment of robot assisted activity to elderly people at a health service facility for the aged. Paper presented at: Intelligent Robots and Systems, 2004. (IROS 2004). Proceedings. 2004 IEEE/ RS) International Conference on.

28. Wada K, Shibata T, Sakamoto K, et al. Analysis of Utterance in Long-Term Robot Assisted Activity for Elderly People. Paper presented at: Advanced Intelligent Mechatronics. Proceedings, 2005 IEEE/ASME International Conference on.

29. Wada K, Shibata T, Saito T, Tanie K. Robot assisted activity at a health service facility for the aged for 17 months: an interim report of long-term experiment. Paper presented at: Advanced Robotics and its Social Impacts, 2005. IEEE Workshop on.

30. Wada K, Shibata T, Sakamoto K, Tanie K. Quantitative analysis of utterance of elderly people in long-term robot assisted activity. Paper presented at: Robot and Human Interactive Communication, 2005. ROMAN 2005. IEEE International Workshop on.

31. Wada K, Shibata T, Saito T, et al. Robot Assisted Activity for Eldery People for One Year-Progress Report of Long-term Experiment. Gerontechnology. 2005.

32. Wada K, Shibata T, Musha T, Kimura S. Effects of robot therapy for demented patients evaluated by EEG. IEEE/RS) International Conference on Intelligent Robots and Systems: IEEE/ RSJ; 2005:2205 - 2210 .

33. Wada K, Shibata T. Robot therapy in a care house - its sociopsychological and physiological effects on the residents. Paper presented at: Robotics and Automation, 2006. ICRA 2006. Proceedings 2006 IEEE International Conference on. 
34. Wada K, Shibata T. Robot Therapy in a Care House - Results of Case Studies -. Paper presented at: Robot and Human Interactive Communication, 2006. ROMAN 2006. The 15th IEEE International Symposium on.

35. Wada K, Shibata T. Living With Seal Robots; Its Sociopsychological and Physiological Influences on the Elderly at a Care House. Robotics, IEEE Transactions on. 2007;23(5):972-980.

36. Wada K, Shibata T. Robot Therapy in a Care House - Change of Relationship among the Residents and Seal Robot during a 2-month Long Study. Paper presented at: Robot and Human interactive Communication, 2007. RO-MAN 2007. The 16th IEEE International Symposium on.

37. Wada K, Shibata T. Social Effects of Robot Therapy in a Care House - Change of Social Network of the Residents for Two Months. Paper presented at: Robotics and Automation, 2007 IEEE International Conference on.

38. Wada K, Shibata T. Social and physiological influences of robot therapy in a care house. Interaction Studies: Social Behaviour and Communication in Biological and Artificial Systems. 2008;9(2):258-276.

39. Giusti L, Marti P. Interpretative Dynamics in Human Robot Interaction. Paper presented at: Robot and Human Interactive Communication, 2006. ROMAN 2006. The 15th IEEE International Symposium on.

40. Kidd CD, Taggart W, Turkle S. A sociable robot to encourage social interaction among the elderly. Paper presented at: Robotics and Automation, 2006. ICRA 2006. Proceedings 2006 IEEE International Conference on.

41. Taggart W, Turkle S, Kidd C. An Interactive Robot in a Nursing Home: Preliminary Remarks. Paper presented at: In: Towards Social Mechanisms of Android Science, Cognitive Science Society, 2005 .

42. Marti P, Bacigalupo M, Giusti L, et al. Socially Assistive Robotics in the Treatment of Behavioural and Psychological Symptoms of Dementia. Paper presented at: Biomedical Robotics and Biomechatronics, 2006. BioRob 2006. The First IEEE/RAS-EMBS International Conference on.

43. Sakairi K. Research of robot-assisted activity for the elderly with senile dementia in a group home. Paper presented at: SICE 2004 Annual Conference.

44. Kanamori $\mathrm{M}$, Suzuki $\mathrm{M}$, Oshiro $\mathrm{H}$, et al. Pilot study on improvement of quality of life among elderly using a pet-type robot. Paper presented at: Computational Intelligence in Robotics and Automation, 2003. Proceedings. 2003 IEEE International Symposium on.

45. Libin AV, Libin EV. Person-robot interactions from the robopsychologists' point of view: the robotic psychology and robotherapy approach. Proceedings of the IEEE. 2004;92(11):17891803. 
46. Turkle S, Taggart W, Kidd CD, Daste O. Relational artifacts with children and elders: The complexities of cybercompanionship. Connection Science. 2006;18(4):347-361.

47. Hamada T, Okubo H, Shimada Y, et al. Effective Method of Robot Therapy in a Nursing Home -Study on Intervention of Therapy. Paper presented at: SICE-ICASE, 2006. International Joint Conference.

48. Tapus A. Improving the Quality of Life of People with Dementia through the Use of Socially Assistive Robots. Paper presented at: Advanced Technologies for Enhanced Quality of Life, 2009. AT-EQUAL '09.2009.

49. Tapus A, Tapus C, Mataric MJ. The use of socially assistive robots in the design of intelligent cognitive therapies for people with dementia. Paper presented at: Rehabilitation Robotics, 2009. ICORR 2009. IEEE International Conference on. 


\section{State of the art in socially assistive robots for elderly care}

This chapter was submitted as:

Bemelmans R, Gelderblom GJ, Jonker P, de Witte L.

State of the art in socially assistive robots for elderly care. 


\section{CHAPTER 3}

\section{Abstract}

The purpose of this study was to describe the state of the art in Socially Assistive Robots (SAR) for application in long term elderly care. A desk research in both the formal and grey literature was conducted. A web based search for SAR systems in databases (CORDIS, IEEE), journals and proceedings of, HRI, RIA, ICORR, ICRA, ROMAN, IEEE and IFRR conferences was carried out. Further a free Google and Google scholar based search was executed. A collection of systems was built in 4 steps. In the first step all interactive robot systems were brought together. In the following steps socially assistive robots were selected based on their suitability for application in (long term) elderly care. A set of 25 socially assistive robots potentially suitable for elderly care was selected. Despite the vast amount of research and prototype development in this field only a limited number of socially assistive robots are actually available to be put to use within elderly care. Gathering relevant user needs and setting up evidence based directions for possible robot interventions in elderly care is necessary. 


\section{Introduction}

The ongoing development of technology in many fields including robotics offers an increasing potential for application within healthcare. Such technology may provide innovative quality enhancement of care processes traditionally dominated by human care provision. The ongoing demographic developments in Western societies may function as a catalyst in countering the current hesitation in embracing technology in support of long term care provision.

Research into robotics supporting health care took off already some decades ago but mainly developed into systems for motor rehabilitation therapy and assistive technology supporting individuals in their activities of daily living (ADL) ${ }^{1}$. Besides high development costs and small markets the technical challenges still face the development of such robots regarding safety, robustness and reliability. In contrast the relatively new field of robotic applications supporting social interaction behavior is under much faster development ${ }^{2}$. In a relatively short period, systems have become available supporting child's social interaction through play, e.g. ${ }^{3}$ and care for elderly with dementia, e.g. ${ }^{4}$. For the development of socially assistive robots (SAR) the challenges do not so much concern technical feasibility but rather the development of robot behavior to match the user's needs.

SAR's can have a role in assisting people similar to the role guide dogs have for visually impaired people. They can be a buddy giving companionship, a sense of safety and supporting social activity. More specifically, Marti et al. ${ }^{5}$ address these robot systems as capable of mediating social interaction, not designed to help the human being performing work tasks or saving time in routine activities, but to engage people in personal experiences stimulated by the physical, emotional and behavioral affordances of the robot. Feil-Seifer et al. ${ }^{6}$ define socially assistive robotics (SAR) as the intersection of assistive robotics (AR), one that gives aid or support to a human user, and socially interactive robotics (SIR). In SIR, the robots goal is to develop close and effective interactions with the human for the sake of interaction itself. In SAR the robot's goal is to create close and effective interaction with a human user for the purpose of giving assistance and achieving measurable progress in convalescence, rehabilitation, learning, etc. 
The uptake of these systems in elderly care practice so far has been limited despite the emerging evidence of the potential added value of such systems in care provision ${ }^{7},{ }^{8}$. As a starting point the state of the art on applicable (available and suitable) socially assistive robots (SAR's) needs to be provided. In general the needs perceived within elderly care need to be taken as starting point for better understanding the potential application domain for SAR ${ }^{9}$. When applying the International Classification of Functioning, Disability and Health (World Health Organization, ICF-classification), Socially Assistive Robots are environmental factors in the context of Activity and Participation. The domains General Tasks and Demands, Communication, Interpersonal Interactions and Relationships and to some extent Recreation and Leisure are the classifications indicating the health domains when applying socially assistive robots.

The purpose of this paper was to give an overview of the state of the art on applicable SAR's for elderly care.

\section{Methods}

A desk research in both the formal and grey literature was conducted. A web based search for SAR systems in databases (CORDIS, IEEE digital library), journals and proceedings of HRI, RIA, ICORR, ICRA, ROMAN and IFRR conferences was carried out. Further, a free Google and Google scholar based search was executed. Selected systems then went through a selection process involving 3 reviewers. The selection process was based on a brief description of the functionality of the robot, a picture and -where available- the intended application of the robot. The objective of the search was to find available socially assistive robots potentially suitable for elderly care.

Through four iterations a set of available socially assistive robot systems suitable for elderly care was gathered, selected and filtered.

In the first step (ie, the database search) the following search terms were used: 'social* robot*', 'assist* robot*', 'interact* robot*'. By using the asterisk (*) the term becomes a prefix. So 'interact*'*' represents among others 'interacting' and 'interactive'. 
In the second step, the taxonomy described by Fong ${ }^{10}$ defining the properties of socially interactive robots was applied to narrow down the initial list of robots to a list featuring interactive robots. The eight properties defining socially interactive robots as defined by Fong were: embodiment, emotion, dialog, personality, human-oriented perception, user modeling, socially situated learning, and intentionality. One reviewer (ie, author R.B.) judged the matching of the robots for each property on a 3 -point scale (ie, $O=$ no match, $1=$ partial match, $2=$ full match). To limit the change of excluding relevant robots, a low total score was used as selection criterion, ie, all systems with a total score of at least 8 points (equal to an average of 1 point per property) were selected. In this step similar systems with similar properties were also excluded.

In the third step the taxonomy described by Feil-Seifer et al. ${ }^{6}$, an extension of the taxonomy described by Fong, defining the properties of socially assistive robots was applied to narrow down the list of robots to a list featuring socially assistive robots possibly suitable for elderly care. The four extended properties defining SAR suitable for elderly care were: user population (elderly), task examples (physical therapy, daily life assistance or emotional expression), sophistication of interaction (speech, gestures or direct input), and role of the robot (physical, cognitive or emotional assistance). Three reviewers (ie, authors R.B., G.J.G., and L.d.W.) were equally instructed to independently judge the relevance of the systems based on the four properties described by Feil-Seifer. The reviewers judged the matching of the robots for each property on a 3 -point scale (ie, $\mathrm{O}=$ no match, $1=$ partial match, $2=$ full match). All systems with a total score of at least 12 points (equal to an average of 1 point per property) were selected.

In the fourth and last step the 3 reviewers discussed the remaining robots and excluded SAR's which were believed not to be suitable for elderly care.

Given the aim of this article, to present an overview of available SAR's potentially suitable for elderly care, no systems were excluded on the basis of their technology readiness level (TRL) or intended application. 


\section{CHAPTER 3}

\section{Results}

After the first step a list of 113 relevant robot systems was obtained. In table 1 the robots are categorized by the five innovation areas introduced by Butter et al, comprising the whole domain of healthcare robotics ${ }^{1}$. According to Butter et al. socially assistive robotics are part of the subcategory "Robot assisted mental, cognitive and social therapy" of the innovation area "Robotics for rehabilitation treatment". Some of the selected robots can be categorized in more than one innovation area, therefore the sum of the second column exceeds the number of selected robots. Full references can be obtained from the authors.

In the second step, the initial list was narrowed down to 39 socially interactive robots. In the third step the list was further narrowed down to 28 SAR's, of which 3 systems had a review score of 24 (maximum score). Table 2 shows the weighted Cohen's kappa coefficient for the inter-rater agreement among the 3 reviewers. In the last step a final set of 25 available SAR's potentially suitable for elderly care was selected. In table 3 these robots are listed.

The resulting robots are companion type systems. The majority of these systems are still prototypes aimed at research. At the moment only Pleo and Paro are fully market available, Furby and Aibo are out of production. Some of the other systems can be acquired directly from the inventors (e.g. NeCoRo). Generalizing, these systems are foremost in research or initial phase of development and haven't reached the early adopters phase yet.

Table 1. Categorization of robots after the first step ( $n=113)$

\section{Innovation area}

Robotic assisted preventive training and diagnosis

Robotic assistive systems

Robots supporting professional care

Robotics for rehabilitation treatment

Robotics for medical intervention
\# products

43

31

5

58

8 


\section{Step 1.}

113 robots were selected from major databases, proceedings and Google search.

Criteria: social* robot*', 'assist* robot*', 'interact* robot*

\section{Step 2.}

39 robots were selected, by one reviewers.

Criteria: socially interactive robots

\section{Step 3.}

28 robots were selected, by three reviewers.

Criteria: socially assistive robots for elderly care.

\section{Step 4 .}

25 robots remained after a group discussion, by three reviewers.

Criteria: specifically suitable for elderly care

Figure 1. Schematic overview of selection process with search results

Table 2. Reviewers' Inter-Rater Agreement

\section{Weighted Cohen's kappa coefficient}
R.B. G.G.
R.B L.d.W.
L.W. G.G.

\begin{tabular}{llll}
\hline step 3 & 0.64 & 0.41 & 0.54 \\
\hline
\end{tabular}


Table 3. Socially Assistive Robots suitable for elderly care

\begin{tabular}{|c|c|c|c|c|c|}
\hline & robot & intended use & description & $\begin{array}{l}\text { for } \\
\text { elderly }\end{array}$ & image \\
\hline 1 & Ifbot & $\begin{array}{l}\text { Communication } \\
\text { robot aimed } \\
\text { to provide } \\
\text { comforting } \\
\text { conversations as } \\
\text { a member of the } \\
\text { family. }\end{array}$ & $\begin{array}{l}\text { Robot with moving eyes } \\
\text { and neck, voice and } \\
\text { direction recognition } \\
\text { microphone and a } \\
\text { handshake sensor. }\end{array}$ & & 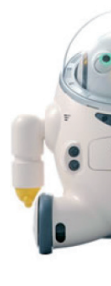 \\
\hline 2 & Nursebot & $\begin{array}{l}\text { Research platform } \\
\text { to test out a } \\
\text { range of ideas } \\
\text { for assisting } \\
\text { elderly people, } \\
\text { e.g. Intelligent } \\
\text { reminding, tele- } \\
\text { presence and } \\
\text { social interaction. }\end{array}$ & $\begin{array}{l}\text { Prototype personal } \\
\text { mobile robotic assistant } \\
\text { that can recognize } \\
\text { speech, follow } \\
\text { patients around and } \\
\text { communicate via touch } \\
\text { screen. }\end{array}$ & $w *$ & \\
\hline 3 & PeopleBot & $\begin{array}{l}\text { A drive robot } \\
\text { designed } \\
\text { for service } \\
\text { and human- } \\
\text { interaction } \\
\text { projects. }\end{array}$ & $\begin{array}{l}\text { The mobile robot } \\
\text { includes a touchscreen, } \\
\text { a gripper to pick up } \\
\text { objects, navigates } \\
\text { autonomously and } \\
\text { avoids obstacles, and } \\
\text { can recognize people } \\
\text { and speech. }\end{array}$ & $*$ & \\
\hline 4 & Sparky & $\begin{array}{l}\text { A platform } \\
\text { for live video } \\
\text { telepresence } \\
\text { and remote } \\
\text { autonomous } \\
\text { roving. }\end{array}$ & $\begin{array}{l}\text { Remote, via internet, } \\
\text { controllable robot with } \\
\text { video chat features. }\end{array}$ & & \\
\hline
\end{tabular}




\begin{tabular}{|c|c|c|c|c|c|}
\hline & robot & intended use & description & $\begin{array}{l}\text { for } \\
\text { elderly }\end{array}$ & image \\
\hline 5 & NeCoRo & $\begin{array}{l}\text { A study on pet } \\
\text { robots. }\end{array}$ & $\begin{array}{l}\text { Cat type robot that } \\
\text { interacts with people, } \\
\text { verbal (e.g. meow, } \\
\text { purr) and nonverbal } \\
\text { (stretching paws, turning } \\
\text { head), as if it is alive. }\end{array}$ & & \\
\hline 6 & Huggable & $\begin{array}{l}\text { Developed for } \\
\text { healthcare, } \\
\text { education } \\
\text { and social } \\
\text { communication } \\
\text { applications, } \\
\text { being a member } \\
\text { of a triadic } \\
\text { interaction. }\end{array}$ & $\begin{array}{l}\text { Interactive teddy bear } \\
\text { like robotic companion. } \\
\text { With full body sensitive } \\
\text { skin, video cameras } \\
\text { (eyes), microphones } \\
\text { (ears) and wireless } \\
\text { networking. }\end{array}$ & $*$ & \\
\hline 7 & $\begin{array}{l}\text { My Real } \\
\text { Baby }\end{array}$ & $\begin{array}{l}\text { Toy developed for } \\
\text { children. }\end{array}$ & $\begin{array}{l}\text { A doll with animatronics } \\
\text { and emotional response }\end{array}$ & & \\
\hline 8 & Probo & $\begin{array}{l}\text { Research platform } \\
\text { for technical, } \\
\text { medical and } \\
\text { social and } \\
\text { psychological } \\
\text { applications } \\
\text { with a focus on } \\
\text { children. }\end{array}$ & $\begin{array}{l}\text { Imaginary huggable } \\
\text { animal type with facial } \\
\text { expressions, gestures } \\
\text { and speech. }\end{array}$ & $*$ & \\
\hline 9 & Furby & $\begin{array}{l}\text { Interactive pet toy } \\
\text { for children. }\end{array}$ & $\begin{array}{l}\text { Domestically-aimed } \\
\text { toy robot with facial } \\
\text { movements }\end{array}$ & & \\
\hline
\end{tabular}




\begin{tabular}{llll}
\hline robot & intended use & description & $\begin{array}{l}\text { for } \\
\text { elderly }\end{array}$ \\
10 & Robovie \\
$\mathrm{R}_{3}$ & $\begin{array}{l}\text { Research platform } \\
\text { for assisting } \\
\text { elderly and } \\
\text { handicapped } \\
\text { people. }\end{array}$ & $\begin{array}{l}\text { Crowd-monitoring } \\
\text { humanoid robot that } \\
\text { recognizes when people } \\
\text { are lost and helps them } \\
\text { find their way }\end{array}$ \\
\end{tabular}

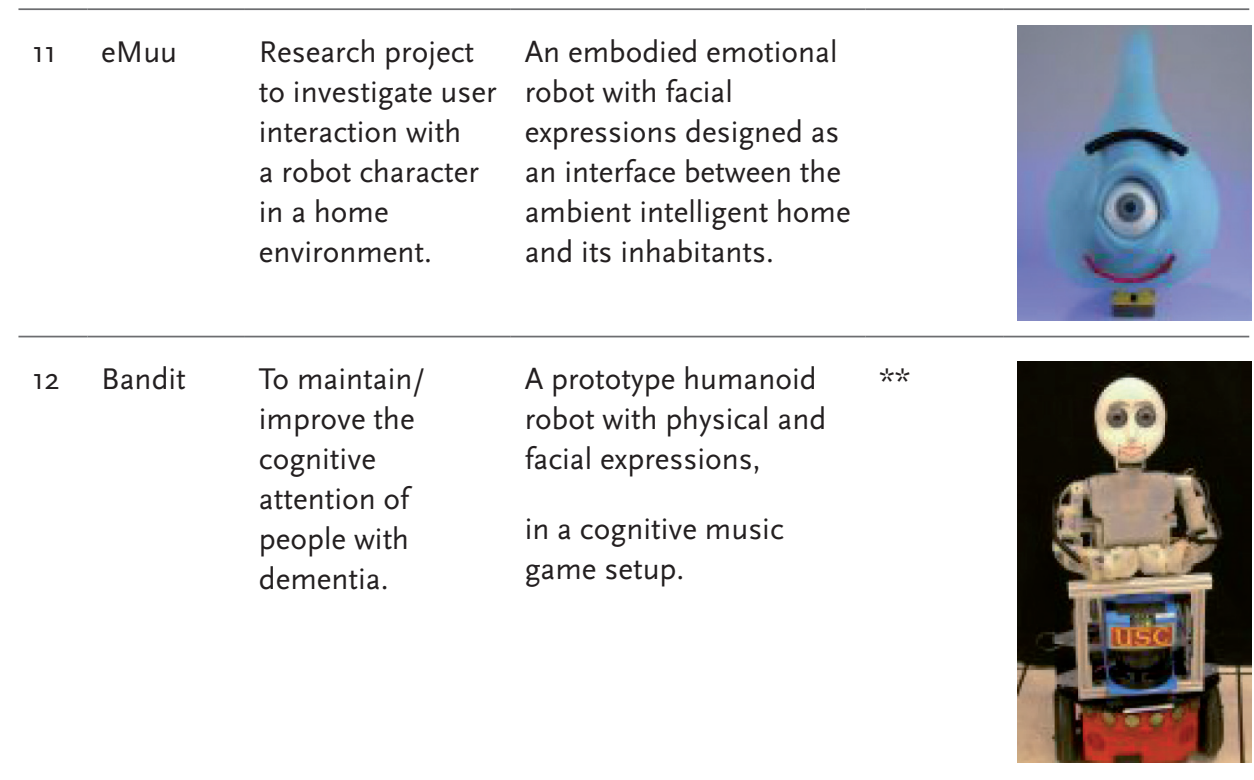

\begin{tabular}{ll}
\hline 3 iCat $\quad \begin{array}{l}\text { To investigate } \\
\text { Human-Machine } \\
\text { communication. }\end{array}$ & $\begin{array}{l}\text { A desktop user-interface } \\
\text { robot that is capable of } \\
\text { verbal communication } \\
\text { and mechanically } \\
\text { rendering facial } \\
\text { expressions. }\end{array}$ \\
\hline \multirow{2}{*}{ AIBO $\quad \begin{array}{l}\text { Commercial } \\
\text { companion robot. }\end{array}$} & $\begin{array}{l}\text { A dog-like robot that } \\
\text { can see, hear, and } \\
\text { understand commands. } \\
\text { Has the ability to } \\
\text { learn, to adapt to its } \\
\text { environment, and to } \\
\text { express emotion. }\end{array}$ \\
&
\end{tabular}




\begin{tabular}{|c|c|c|c|c|c|}
\hline & robot & intended use & description & $\begin{array}{l}\text { for } \\
\text { elderly }\end{array}$ & image \\
\hline 15 & Paro & $\begin{array}{l}\text { A therepeutic } \\
\text { robot for people } \\
\text { with dementia. }\end{array}$ & $\begin{array}{l}\text { A mental-commit baby } \\
\text { seal robot which can } \\
\text { perceive people and } \\
\text { its environment. By } \\
\text { interaction with people it } \\
\text { responds as if it is alive. }\end{array}$ & $* *$ & \\
\hline 16 & Pleo & $\begin{array}{l}\text { Commercial toy } \\
\text { robot. }\end{array}$ & $\begin{array}{l}\text { A Dinosaur that looks, } \\
\text { moves, and behaves } \\
\text { in ways that trigger a } \\
\text { "belief of life". }\end{array}$ & & \\
\hline 17 & Kaspar & $\begin{array}{l}\text { Child-sized } \\
\text { humanoid to help } \\
\text { autistic children } \\
\text { learn about social } \\
\text { interaction. }\end{array}$ & $\begin{array}{l}\text { A therapeutic robot with } \\
\text { moving head, neck, arms } \\
\text { and hands and a mouth } \\
\text { capable of opening and } \\
\text { smiling. }\end{array}$ & $*$ & \\
\hline 18 & Homie & $\begin{array}{l}\text { An artificial } \\
\text { companion dog } \\
\text { for elderly people. }\end{array}$ & $\begin{array}{l}\text { A companion dog- } \\
\text { like robot with facial } \\
\text { expression and gesture, } \\
\text { and communication } \\
\text { features. }\end{array}$ & $* *$ & \\
\hline 19 & Sage & $\begin{array}{l}\text { Designed to } \\
\text { attract people to } \\
\text { exhibits. }\end{array}$ & $\begin{array}{l}\text { Multimedia system } \\
\text { that provides video and } \\
\text { audio enhancements to } \\
\text { museum visitors. }\end{array}$ & & \\
\hline
\end{tabular}




\begin{tabular}{|c|c|c|c|c|c|}
\hline & robot & intended use & description & $\begin{array}{l}\text { for } \\
\text { elderly }\end{array}$ & image \\
\hline 20 & Cero & $\begin{array}{l}\text { To assist partly } \\
\text { motion-impaired } \\
\text { users with the } \\
\text { transportation } \\
\text { of light objects } \\
\text { in an office } \\
\text { environment. }\end{array}$ & $\begin{array}{l}\text { A fetch-and-carry service } \\
\text { robot. }\end{array}$ & $*$ & \\
\hline 21 & Nexi & $\begin{array}{l}\text { To support } \\
\text { research and } \\
\text { education goals } \\
\text { in human-robot } \\
\text { interaction, } \\
\text { teaming, and } \\
\text { social learning. }\end{array}$ & $\begin{array}{l}\text { Small mobile humanoid } \\
\text { robot that possess a } \\
\text { combination of mobility, } \\
\text { moderate dexterity, } \\
\text { and human-centric } \\
\text { communication and } \\
\text { interaction abilities. }\end{array}$ & & \\
\hline 22 & Maggie & $\begin{array}{l}\text { Research platform } \\
\text { to study close } \\
\text { peer-to-peer } \\
\text { human robot } \\
\text { interaction. }\end{array}$ & $\begin{array}{l}\text { Robot with movable } \\
\text { body, arms, head and } \\
\text { eyes, able to talk and } \\
\text { recognise voice. }\end{array}$ & & \\
\hline 23 & Leonardo & $\begin{array}{l}\text { Research project } \\
\text { for human robot } \\
\text { interaction with } \\
\text { a high emotional } \\
\text { expression robot. }\end{array}$ & $\begin{array}{l}\text { Capable of near-human } \\
\text { facial expressions. }\end{array}$ & & \\
\hline 24 & Mir-H & $\begin{array}{l}\text { Service robot } \\
\text { for home } \\
\text { environments. }\end{array}$ & $\begin{array}{l}\text { Robot with internet and } \\
\text { mobile technologies, } \\
\text { remote monitoring, } \\
\text { entertainment and home } \\
\text { networking. }\end{array}$ & & \\
\hline 25 & PaPeRo & $\begin{array}{l}\text { An interactive } \\
\text { partner for } \\
\text { humans in home } \\
\text { environments. }\end{array}$ & $\begin{array}{l}\text { A mobile } \\
\text { communication robot, } \\
\text { with object detection } \\
\text { and a face and speech } \\
\text { recognition system. }\end{array}$ & & \\
\hline
\end{tabular}

a blank = not specifically designed for (health) care; * = (also) designed for (health) care; ** $=$ (also) designed for elderly (health) care. 


\section{Discussion}

We have searched in formal scientific databases and free on the Internet. All robot systems described in the formal databases are also found with free search on the Internet, but conversely not all systems found with the free search were found in the formal scientific databases. We assume that the reason for this is that the developers intended to accessibly promote their innovative and progressive agenda and to encourage discussions and enlarge the insights on potential applications. Another factor is that, in general, consumer industry does not publish in the scientific literature.

The goal of this paper is to present an overview of socially assistive robots with potential use in elderly care. Although we used the definition given by Fong ${ }^{10}$ and Feil-Seifer ${ }^{6}$ in selecting the robots, it is still a rather subjective list. The majority of these robots are still in early stages of development and have not reached the market yet, let alone elderly care. The potential use based on the added value of these robots depends strongly on the type of intervention and the assumed outcomes. Research is needed to determine these interventions and their outcomes.

It's interesting to notice that in many descriptions and literature concerning SAR's (and social robotics in general) the remark is made that it is not (or can't be) a replacement for human care givers. Apparently there is some reluctance towards social robots in a care context, probably due to ethical issues and the general conviction that caring is a human property.

Despite all the research and prototype development in the field of robotics, in particular in socially assistive robotics, only very few of these robot systems actually have become available on the market. Maybe not all developments have the potential to actually make it to the market but there seems to be a general gap between research \& development and product delivery to the market. This not only contrasts the considerations initiating most of these projects but it also limits the possibilities of conducting real life trials and developing therapeutic interventions for elderly care. These interventions will be essential in demonstrating the added value of this specific type of robot technology for long term elderly care. 
In socially assistive robotics the technical demands are not the critical success factors, the human-robot interaction related affordances of the robot in appealing to the cognitive and emotional functioning of the users are ${ }^{11}$.

This all challenges us in gathering relevant user needs and setting up evidence based directions for possible robot interventions and follow-on robot development.

\section{Conclusion}

We searched formal and grey literature and found 25 socially assistive robot systems potentially suitable for elderly care. Despite the vast amount of research and prototype development in this field only a limited number of socially assistive robots are actually available to be put to use within long term elderly care.

\section{References}

1. Butter M, Boxtel Jv, Kalisingh S, Gelderblom G), and others. Robotics for Healthcare, State of the art report. TNO, commissioned by the European Commission, DG Information Society;2007.

2. Butter M, Rensma A, Boxtel Jv, Kalisingh S, and others. Robotics for Healthcare, Final Report. TNO, commissioned by the European Commission, DG Information Society;2008.

3. PROFACTOR. Iromec, Interactive Robotic Social Mediators as Companions 2009; http:// www.Iromec.org.

4. Wada K, Shibata T, Asada T, Musha T. Robot therapy for Prevention of Dementia at Home. Journal of Robotics and Mechatronics. 2007:691-697.

5. Marti P, Bacigalupo M, Giusti L, Mennecozzi C, Shibata T. Socially Assistive Robotics in the Treatment of Behavioural and Psychological Symptoms of Dementia. Paper presented at: Biomedical Robotics and Biomechatronics, 2006. BioRob 2006. The First IEEE/RAS-EMBS International Conference on2006.

6. Feil-Seifer D, Mataric MJ. Defining socially assistive robotics. Paper presented at: Rehabilitation Robotics, 2005. ICORR 2005. 9th International Conference on2005.

7. Bemelmans R, Gelderblom G), Jonker P, de Witte L. The Potential of Socially Assistive Robotics in Care for Elderly, a Systematic Review. Human-Robot Personal Relationships; 2011; Leiden, Netherlands. 
8. Broekens J, Heerink M, Rosendal H. Assistive social robots in elderly care: A review. Gerontechnology. 2009;8(2):94-103.

9. Beer JM, Prakash A, Mitzner TL, Rogers WA. Understanding robot acceptance. Georgia Institute of Technology. 2011.

10. Fong T, Nourbakhsh I, Dautenhahn K. A Survey of Socially Interactive Robots. Robotics and Autonomous Systems. 2003;42:143-166.

11. Heerink M, Krse B, Evers V, Wielinga B. Responses to a social robot by elderly users. Paper presented at: Intelligent Robots and Systems, 2008. IROS 2008. IEEE/RSJ International Conference on2008. 


\section{Development of robot interventions for intramural psychogeriatric care}

This chapter was published as:

Bemelmans R, Gelderblom G), Spierts N, Jonker P, de Witte L. Development of robot interventions for intramural psychogeriatric care.

GeroPsych: The Journal of Gerontopsychology and Geriatric Psychiatry 2013;26(2):113-120. DOI 10.1024/1662-9647/a000087. 


\section{CHAPTER 4}

\section{Abstract}

Social Robots are more and more seen to have great potential for long term care.

However, the actual application of Social Robots in daily care provision will depend on demonstrated added value of such systems in practice. To reach added value, availability of a technical system as such is insufficient. Care interventions need to be defined describing the goal, target group, environment, and how care staff should act to pursue effective application of a robot system. For the seal robot Paro three such interventions have been developed in collaboration with psychogeriatric care professionals. The developed interventions also outline the application of Paro in care for a subsequent effectiveness study. 


\section{Introduction}

The advances in technology offers a vast potential of opportunities for the innovation in care in European countries and beyond. On the basis of technologies such as IT and robotics, applications are feasible, facilitating elements of independence for elderly clients with disability or chronic conditions, who are now dependent on regular human support. Moreover, professionals and informal caregivers could also be supported in their work through innovative technology. In the case of robotics, technology may support the execution of physically demanding tasks, by offering force exertion, repetitive task execution and/or high precision manipulation. The need for autonomy and the limited availability of care providers make the quest for technological support relevant. Moreover, the possible increase of care quality plays a role. A robot is able to process data in a very fast and objective manner, does not become sick or tired, has no stress and carries out its tasks with a high degree of exactitude.

By the increasing technological developments the costs of this technology decreases and people become more and more familiar with technological appliances. Moreover, patients are less dependent on (human) care providers, which can reinforce the feeling of self-control and autonomy. These robot capabilities were the basis for successful robot applications in other domains than care. Despite efforts for more than two decades, this potential has, so far, not been translated into successful applications for the domain of long term care, with some exceptions (Butter, Rensma, Boxtel, Kalisingh, \& and others, 2008). As explanation for this, technical barriers in terms of system reliability, robustness, and intrinsic safety can be mentioned. More recently the use of robot abilities has led to a fast developing alternative application type; social robots. Social robots do not exert significant forces to the human body and may not even be required to make physical contact with users for their functioning. Multimodal interfacing mimics social interaction between human and robot, potentially offering support at a psychosocial level in long term care. For such applications, system robustness, reliability, and intrinsic safety are easier to achieve than the more physical types of care robots, thus paving the way to application of robots in daily care. 
However, for the successful application of any type of robot technology in care, the availability of a sound technical system by itself is not sufficient. The uptake of a robot requires embedding in a care intervention. Such intervention defines the use of the robot for its target population(s) in care provision. Moreover, the intention of the intervention should be specified and the intended effects, or the expected added value from use of the system, should be clarified. Finally, information and/ or instructions for both care receivers and providers must be available. In all, the intervention must convince (public) care financers to reimburse the application of robot interventions within the healthcare system. Without the context of an intervention it is most likely that the application of the robot in care will be seen as an entertaining gadget only.

Within the more specific domain of socially assistive robotics (SAR) 25 systems have become available in recent years (Bemelmans, Gelderblom, Jonker, \& de Witte, 2012b). Of these only few actually became available on the market. Literature reviews revealed that little is known about the effects of these systems in healthcare (Bemelmans, Gelderblom, Jonker, \& de Witte, 2012a; Broekens, Heerink, \& Rosendal, 2009). The application of SAR and certainly their effects in elderly care have not been studied comprehensively and very few academic publications were found. Only for four SAR systems, Paro (K. Wada, Shibata, Saito, \& Tanie, 2002), Aibo (Libin \& Libin, 2004), NeCoRo (T. Tamura et al., 2004), and Bandit (Tapus, Tapus, \& Mataric, 2009), care related effects were reported and even for these systems, results are still limited, as no clinical trials (e.g. RCT) are reported.

The development of SAR's for psychogeriatric care is partly inspired by the reported effects of Animal Assisted Therapy (AAT) (Banks \& Banks, 2002; Kazuyoshi Wada, Shibata, Musha, \& Kimura, 2008). Positive effects are also reported when using dolls in therapeutic interventions for psychogeriatric care (James, Mackenzie, \& Mukaetova-Ladinska, 2006; Toshiyo Tamura et al., 2001). SAR's could possibly combine the best of both; without having the disadvantages of real live animals in dementia care, and with the availability of interactive dynamic features of a robot compared to the more static nature of dolls. 
This paper reports a study aimed at developing interventions for the Paro seal robot. The results must benefit care providers, care takers, government, care financers, and product developers. Paro was selected for this purpose because, of the four systems mentioned, it is the only system with the European CE mark, guaranteeing basic technical robustness, reliability, and intrinsic safety. Moreover, the large number of publications from the Paro developing team on application and effects support the potential of Paro (Bemelmans, et al., 2012a).

Improving quality of care or being able to maintain the current level of care in situations where less staff is available, by supporting daily care provision, is the main objective of this study. To reach added value care interventions need to be defined describing the goal, target group, environment, and how care staff should act to pursue effective application of a robot system. To achieve meaningful interventions for daily care practice it is necessary that health care professionals are intensively involved and leading in the creation process of these interventions. The interventions should provide information on the aims of Paro application in daily care for psychogeriatric patients and describe concrete outcomes to monitor the added value of robot interventions. The developed interventions also outline the application of Paro in care for a subsequent effectiveness study.

The interventions proposed in this paper have been developed in collaboration with four Dutch care institutions providing dementia care: Dignis, Sevagram, Proteion, and Meander.

\section{Methods}

The application of Paro cannot be a goal in itself. The development of interventions involving Paro must be based on the potential of Paro to add value to existing care provision. For this reason the development was based on the expertise of the staff of four care providing organizations. Sevagram, located in Heerlen has in total 2500 employees, Proteion employs 1400 care professionals, Dignis (part of the Lentis group) employs 4500 care professionals, and Meander has 2200 employees. All four offer both intramural and extramural elderly care, both psychogeriatric care and somatic care. 
Meeting $\urcorner \mathrm{A}$

Participants: nursing staff

Objective: potential goals, target population, environment

\section{Meeting $1 \mathrm{~B}$}

Participants: therapists, medical doctors

Objective: potential goals, target population, environment

Analyzing and combining results from meetings $1 \mathrm{~A}$ and $\mathrm{l} \mathrm{B}$

Participants: research team

Objective: final list of potential goals, target population, environment

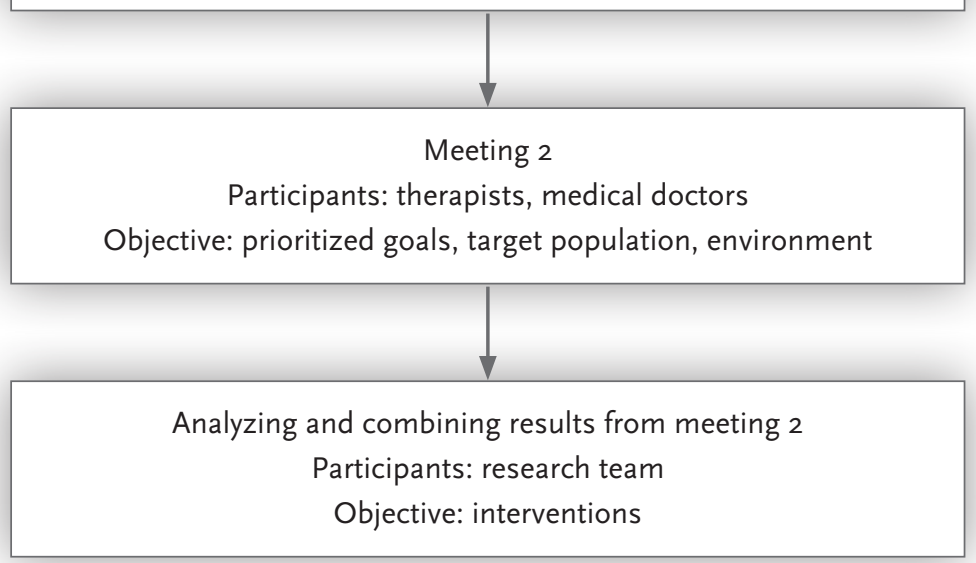

Figure 1. Schematic view of the overall design

In collaboration with the four organizations, a total of twelve meetings with care staff were organized, three in each organization. Figure 1 presents an overall view of the procedure. Initially two meetings (meetings $1 \mathrm{~A}$ and $1 \mathrm{~B}$ ) were arranged in each organization for the purpose of specifying goals, target groups, and environments for the application of Paro in intramural psychogeriatric care. The participants in the meetings were selected based on their expertise, so that all disciplines involved in psychogeriatric care were adequately represented. In one meeting (meeting $1 \mathrm{~A})$, daily care providing personnel was involved, including nurses, diversional therapists, and team leaders. In the other meeting (meeting $1 \mathrm{~B}$ ) therapists were involved, including psychologists, physical therapists, occupational therapists, and medical doctors. The two groups met separately to offer opportunity for all staff to express their opinions without hierarchical confounding. 


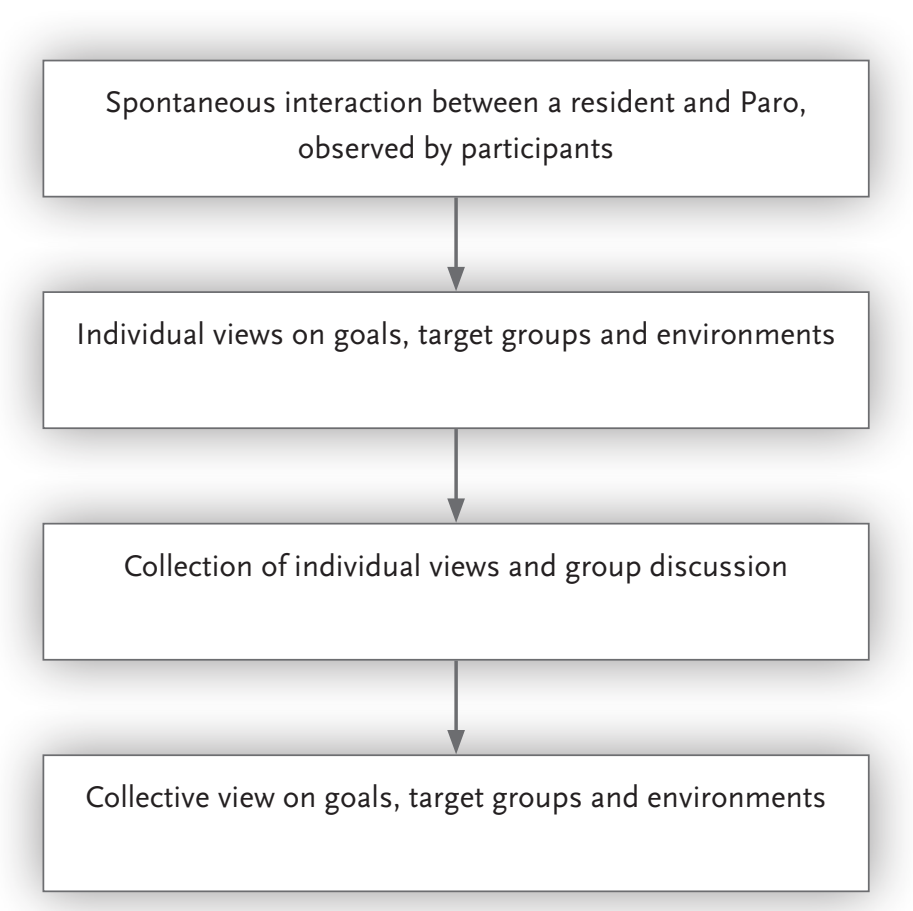

Figure 2. Procedure in meetings $1 A$ and $1 B$, based on the Metaplan method

For both meetings, $1 \mathrm{~A}$ and $1 \mathrm{~B}$, at each site, an identical procedure was adopted (see figure 2), based on the Metaplan method (Schnelle \& Stoltz, 1987). This is a form of gathering qualitative information from field experts, comparable with the focus group approach. First an interaction was arranged between a resident and Paro, witnessed by the participating group of staff. For the involvement of each patient, written informed consent was obtained from their legal representative. Paro was introduced by one of the staff members and spontaneous interaction was observed and recorded on video. The video recordings were made as a possible substitute in others meetings, in the case no life interaction between a resident and Paro was possible. This unstructured interaction was meant to introduce the functionality of Paro to the attending staff members, as they were largely unfamiliar with Paro at that point. Following this, participants were invited to record their individual views on: potential goals, target populations, and environments for Paro application. These views were subsequently shared within the group and followed by a group discussion to clarify the collected material. Results of all discussion meetings were gathered and analysed in combination. 
After the results of the first meetings were reported back to the participants, a last meeting (meeting 2) was organized in each organization, for which the therapists and medical doctors were invited. The aim of this meeting was to prioritize the identified goals of Paro interventions and to determine the type of outcomes and assessment tools that could assess the added value of each of the interventions. Because of the aim of this meeting only the medical doctors and therapists were invited, as it is their task and responsibility to have a professional multidisciplinary view on the priorities and goals in elderly care provision.

Data from all the meetings were brought together as a basis for the formulation of intervention(s) by the research team (i.e. the authors of this paper). In several sessions the research team categorized the collected goals and outlined three concept interventions. These interventions were then sent to the participants of the meetings and their feedback was used to formulate the final interventions.

\section{Results}

\section{First round of meetings}

On the basis of the first two meetings (i.e. $1 \mathrm{~A}$ and $1 \mathrm{~B}$ ) in each care organization a collection of possible goals, target groups, and environments for applying Paro in intramural dementia care was brought together. Due to planning issues one meeting $1 \mathrm{~B}$ was cancelled and 2 were combined ( $\mathrm{A}$ and $1 \mathrm{~B}$ together). In the first meeting (i.e. $1 A$ ) a total of 7 nurses, 6 diversional therapists, and 5 team leaders were involved. In the other meeting (i.e. 1B) in total 4 psychologists, 6 physical therapists, 1 occupational therapist, 2 team leaders, and 2 medical doctors were involved. In total 31 professionals were involved in the first two meetings, evenly distributed among the organizations.

The collected goals concerned both preventive and therapeutic applications. The target patients and the environments for which application would be suitable could not be specified in general terms. The participants agreed this to be highly individual and difficult to outline relevant patient characteristics without further experience with the application of Paro in practice. The participants agreed that, based on the 
four stages of dementia, i.e. Malorientation (stage 1), Time Confusion (stage 2), Repetitive Motion (stage 3), and Vegetation (stage 4) (Feil, 1989), the target patients would have to be in stage 2,3 , or 4 . It was generally believed that stage 1 patients would not accept a toy-like robot, and that there are sufficient alternative interventions for these patients.

In the second round of meetings (i.e. meeting 2) the collected goals were, collectively per organization, prioritized on a 4-point scale. Table 1 lists the collected goals and their prioritization. Some of the goals listed may seem to partially overlap with or incorporate others, there was however no consensus amongst the participants in further reducing or combining the goals.

\section{Second round of meetings}

In total 6 psychologists, 1 physical therapist, 1 occupational therapist, 4 team leaders, and 1 medical doctor were involved. Table 1 shows that the prioritisation, on a 4-point scale ( $0=$ no, $1=$ low, $2=$ medium, and $3=$ high priority), was smoothly distributed over the various goals, i.e. the highest accumulated score was 6 (out of 12) and only 1 goal scored o points. It further shows that no goal was awarded a high priority. It could be concluded that the participants agreed that no goal was evidently more important than the others. It could also be concluded that the participants had no great expectations of the impact of Paro on care provision or well-being in general, as they apparently only proposed medium or low priority goals. The final column in Table 1 shows that a Paro based intervention is not to be seen as care extension, as in an additional tool for diversional therapists among the others tools/activities they facilitate. It also shows that the top 4 individual goals (i.e. $\geq 5$ points) are:

- Making contact, reaction and interaction (Social behavior)

- Reduction of unrest and agitation (Emotion)

- Distraction during nurturing activities (Activity)

- Reduction of loneliness or isolation (Social behavior)

Based on the prioritization the goals were categorized into three main groups. 
Table 1 Prioritized goals

\begin{tabular}{cccc}
\hline Goals & $\begin{array}{c}\text { Organizations } \\
\text { priority }\end{array}$ & $\begin{array}{c}\text { Accumulated } \\
\text { scores }\end{array}$ \\
& $L$ & $S \quad P$ & $M$ \\
\hline
\end{tabular}

(Physical)

Activate moving, incentive to move

(e.g. walking towards Paro)

(Sensorial)

Feeling

Cuddling

Stimulate senses

Fidgeting behavior (people with picking behavior)

(Activity)

$\begin{array}{lllllll}\text { Distraction during nurturing activities / annoying } & 2 & 1 & 1 & 1 & 5\end{array}$ activities

(Re)encourage action / initiative

Day-night rhythm

Sleeping problem reduction

Smoothening eating activity

Creating rest during care activity

Elicit response (verbal, non verbal)

Occupational therapy

Nurturing activity

Autonomy

$\begin{array}{lllll} & 2 & 1 & & 3 \\ 1 & & & & 1 \\ & 1 & & 1 & 2 \\ 1 & & & & 1 \\ 1 & & & & 1 \\ 1 & & 1 & & 2 \\ & & 1 & 1 & 2 \\ & & & 1 & 1 \\ & & & & 1\end{array}$

\section{(Cognition)}

Getting attention

Stimulate cognition

(Emotion)

Express feeling

Evoke emotion

Positive feeling / satisfaction

Caring (loving)

Sense of relaxation and tranquility

Reduction of unrest / agitation or aggression

Reduction problem behavior

Enhance well-being

$$
1
$$

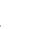

$$
1
$$




\begin{tabular}{|c|c|c|c|c|c|}
\hline \multirow[t]{2}{*}{ Goals } & \multicolumn{4}{|c|}{$\begin{array}{c}\text { Organizations } \\
\text { priority }\end{array}$} & \multirow[t]{2}{*}{$\begin{array}{c}\text { Accumulated } \\
\text { scores }\end{array}$} \\
\hline & $\mathrm{L}$ & $S$ & $P$ & M & \\
\hline More at ease / familiar & 1 & 1 & & & 2 \\
\hline Improving mood & 1 & 1 & 1 & 1 & 4 \\
\hline Reduction of anxiety / fear & 2 & 1 & & & 3 \\
\hline Improving self-worth (dignity) & 1 & & & & 1 \\
\hline Stress reduction & 1 & & & & 1 \\
\hline Depression reduction & 1 & 2 & & & 3 \\
\hline Creating happiness & 1 & 1 & & & 2 \\
\hline Sense of safety and security & 1 & 2 & & 1 & 4 \\
\hline Binding (affection) & 1 & & & & 1 \\
\hline Comfort / reducing grief & 1 & 1 & & 1 & 3 \\
\hline Cosiness & 1 & & & & 1 \\
\hline Reduce loneliness & & & & 1 & 1 \\
\hline Offering affection & & 1 & & 1 & 2 \\
\hline Feeling needed (taking care) & & 2 & 1 & & 3 \\
\hline \multicolumn{6}{|l|}{ (Social behavior) } \\
\hline $\begin{array}{l}\text { Making contact (verbal and non verbal) / reaction } \\
\text { - interaction }\end{array}$ & 2 & 2 & 1 & 1 & 6 \\
\hline Bed Patients: interaction/ reaction and attention & & 2 & & & 2 \\
\hline Stimulate interaction among residents & & & 1 & & 1 \\
\hline Stimulate family-resident interaction & 2 & 2 & & & 4 \\
\hline Increase communication & 2 & 1 & & 1 & 4 \\
\hline Reduce loneliness / isolation & 1 & 2 & 1 & 1 & 5 \\
\hline Regulate behavior & 1 & & & & 1 \\
\hline Company & & 1 & & & 1 \\
\hline \multicolumn{6}{|l|}{ (Work-related) } \\
\hline Reduce absenteeism & 1 & & & & 1 \\
\hline Stress reduction care provider & 1 & & & & 1 \\
\hline Care extention & & & & & o \\
\hline Lowering medication & & 2 & & 1 & 3 \\
\hline
\end{tabular}

\section{Notes.}

The goals (column 1) were collected in meetings $1 \mathrm{~A}$ and $\mathrm{1B}$, and prioritized in meeting 2. Prioritization ranges from $\circ$ (no priority; these are left blank) to 3 (high priority). The prioritization per organization is listed in columns: $L=$ Lenis, $S=$ Sevagram, $P=P r o t e i o n$, and $M=$ Meander. The final column shows the accumulated scores of the four participating organizations. 


\section{CHAPTER 4}

1. Application of Paro for therapeutic purposes. Depending on individual needs Paro can stimulate perception, psychological functioning, psychosocial well-being, and social behavior. For patients at risk, availability of Paro can reactivate the person at individual level.

2. Application of Paro to facilitate daily care activities, making use of the attention focused on Paro or its comforting ability when made available. For care providers the presence of Paro during daily care activities could enhance patients' well-being and thus facilitate the required care activities. Normally, for some patients these daily activities cause anxiety or stress making the task of the care giver more difficult.

3. Application of Paro in support of social visits. For family members it was reported that due to the progressing dementia, attractiveness of family visits to dementia patients is difficult to maintain. The activating qualities of Paro on the patient could be used to provide a shared focus point for both the patient and the family member(s) and stimulate the attractiveness of visits.

Within each of these three categories a Paro intervention was specified.

The first intervention aims at providing comfort to individual distressed dementia patients in critical timeslots during the daily routine. Distress is a common symptom of dementia and may result in distorted day-night activation patterns. Paro is to be used to stimulate perception and activate attention, leading to a sense of purpose in activities. The purpose of this Paro intervention is highly individual and in general of therapeutic nature. The following behaviors give some indication for selecting the patients or residents the intervention would be suitable for: aggression (verbal - physical), physical tension, physical agitation, anxiety, picking, throwing objects, introverted (quiet) or passive behavior. Some goals the participants mentioned specifically were: stimulate senses, getting attention, and relaxation and rest.

The second Paro intervention aims at facilitating the provision of care by professionals. Paro could bring about a desired mindset of the patient, lowering common resistance to ADL care tasks executed by the staff. It might function as a diversion or as a means to bring about a more cooperative mood. The following behaviors give some indication for selecting the patients or residents the intervention would be suitable for: aggression (verbal - physical), physical tension or physical agitation. 
Some goals the participants mentioned specifically were: focusing, relaxation, and fear reduction.

The third Paro intervention aims at supporting social contact between a dementia patient and visiting family members or acquaintances. Paro is then used as an intermediary, facilitating shared attention and conversation. The following behaviors give some indication for selecting the patients or residents the intervention would be suitable for: difficulty to make contact or interact, introverted (quiet) or passive mood and restlessness. Some goals the participants mentioned specifically were: stimulate interaction, reduce loneliness and social isolation, and stimulate action - reaction.

In each of the interventions the application of Paro and supporting activities are described at very practical level. The descriptions clarify the intention and actions to the professional. In addition, information is provided for involved care professionals and family members to prevent common prejudice and resistance to the application of a robotic "toy" for their relatives. The descriptions offer easy accessible information on the robot Paro, its purpose and "how to" in psychogeriatric care provision. In order to introduce, structure, and accompany the development and use of the interventions in daily care practice, a blended learning and training course is developed in collaboration with education experts and care providers. The developed training course will support further implementation of Paro involved interventions.

The topic of the third meeting (i.e. meeting 2) was, besides prioritizing the goals, determining the type of outcomes and suitable assessment tools as evaluation instruments. Participating care professionals reflected on the evaluation criteria as used within care practice and their suitability for evaluating the Paro interventions.

Primary outcome for the first interventions was behavioral change. As assessment tools the Dutch GIP scale (Eisses \& Kluiter, 2002) was suggested (Behavior Observations scale for Intramural Psychogeriatric, only in Dutch). Because of the highly individual nature of problematic behavior in psychogeriatric care, it was recommended to consider tailored versions of observations assessing relevant behavioral change in sufficient detail. As secondary measures the participants mentioned depression, with the Cornell Scale for Depression in Dementia (CSDD) as assessment tool (Alexopoulos, Abrams, Young, \& Shamoian, 1988) and medication use, to be reported by the responsible physician. 
For the second and third intervention the preferred primary outcome was again patient behavior and its impact on either care provision or family visits. It was stressed that suitable assessment criterion needed to be very easy to administer as it would need to be part of the daily care routine. As a solution a tailor made behavior checklist for each patient was suggested, in order to record short term behaviour change. Because of the individual nature of the goals and the desired practicality for the care providers an individual Goal Attainment Scale (GAS) (Kiresuk \& Sherman, 1968) is suggested, in particular the IPPA instrument (Individually Prioritized Problems Assessment) (Wessels et al., 2000). This is a GAS in which several characteristics of a particular behavior are described, and can be scored based on a 5-point ranking scale. Selection or development of the assessment tools will require additional research as part of the development of the subsequent effectiveness study.

\section{Discussion}

Socially Assistive Robots are generally regarded to have great potential for long term care. Robots can contribute in terms of capacity (number of care providers), quality (performing very accurately and task specific), finance (robots support or even take over tasks of trained personal), and independence (e.g. increase feeling of autonomy and self-management). These categories overlap partially but have their own surplus value. An unlimited amount of money would not solve the capacity problem; there are just not enough care givers. On the other hand, enough care providers, and money, do not necessarily improve the quality of care or increase a positive experience.

SAR's can have a role in assisting people similar to the role guide dogs have for visually impaired people. They can be a buddy giving companionship, a sense of safety and supporting social activity. Paro in particular and Socially Assistive Robots in general are often, not surprisingly, associated with companion type pets or creatures, e.g. (Kidd, Taggart, \& Turkle, 2006). In this study however, this is not the case. Paro is to be seen as a tool, to provide diversion and activate or facilitate (shared) attention. 
Despite all the research and prototype development in the field of robotics, in particular in socially assistive robotics, only very few of these robotic systems actually have become available on the market. Maybe not all developments have the potential to actually make it to the market but there seems to be a general gap between research \& development and product delivery to the market. This not only contrasts the considerations initiating most of these projects but it also limits the possibilities of conducting real life trials and developing therapeutic interventions for elderly care.

The uptake of Social Robots in daily care provision will depend on demonstrated added value of such systems in practice. Successful implementation of developed robots and interventions depends highly on the role and contribution of the (end) users (e.g. health care professionals). Without this involvement, embedding social robotics in health care has less chance of success. Too often, still, systems are developed without full involvement, from start to finish, from the intended users. While understandable, there are still major technical challenges involved in SAR, this is a missed opportunity.

Involving care givers from multiple disciplines, from the start, led to a broad and diverse range of potential goals. The participating care givers were enthusiastic and saw, given the collected goals, a lot of potential in the application of robot interventions. Advantage of this approach is also the reduction of resistance to the application of a robotic "toy" in health care. The participants suggested a large amount of potential goals for the application of Paro, indicating its potential. They also, however, awarded none of the goals with a high priority. This should be no surprise because Paro is no panacea in dementia care, it could however be an instrument to assist care providers in their daily work.

The formulation of the three Paro interventions did not only intend to structure the application of Paro in daily care provision. In the context of the ongoing study into the effectiveness of Social Assistive Robots, the interventions are intended to define the way Paro will be evaluated in Dutch care provision during an effectiveness study. In collaboration with the same four care organizations a quasi-experimental study is scheduled to start in the last quarter of 2012. This multicenter intervention study will be conducted in the form of a quasi-experimental time series study with 


\section{CHAPTER 4}

within-subject comparison. Recruitment of subjects will take place via the participating care organizations, aiming at 80 participants. The effectiveness study will be preceded by a small scale pilot study, in order to further detail the interventions and the outcomes to be attached. The results and experiences of this pilot study will also be used to fine-tune the blended learning course material, based on the experienced training demand of the care staff. The planned effectiveness study, involving the developed interventions, will provide insight in the outcomes.

\section{Conclusion}

This study aimed at the development of interventions involving the robot baby seal Paro. Inspired by the intuitive appeal of Paro, four care institutions combined resources and requested a structured development of Paro interventions to ensure effective future application of the robot. The resulting interventions provide not only hands-on instructions for implementing the robot in the provision of daily care, but also a description and definition of the expected effects from Paro and the method to assess these effects. Additional to these descriptions, information for both professional caregivers and informal caregivers is provided to support the effective uptake of the Paro interventions. The set of interventions also define the application of Paro, as will be studied in the subsequent effectiveness study.

The three developed interventions differ in their impact on the provision of care and therefore in the added value they may have. The first intervention aims for a therapeutic effect, the other two interventions emphasize practical benefits. In the application of Paro this provides the opportunity for care organizations to make an informed decision on why and how to introduce Paro as an intervention. For care financers it provides the opportunity to assess the basis for reimbursement of Paro involved interventions. Application of care robots in general can benefit from the definition of interventions embedding robots. In socially assistive robotics the technical demands are not the critical success factors, the human-robot interaction related affordances of the robot in appealing to the cognitive and emotional functioning of the users are. An essential step in this process is sound assessment outcomes of care robotics in daily care provision. Without such assessment reim- 
bursement will continue to be a problem, undermining the application and further development of socially assistive robotics.

The results of this study provide the basis for the methodology of the effectiveness study to be executed. If the developed interventions are reliably, accepted, and perform to satisfaction this research can provide a significant contribution in the improvement of the wellbeing of the patients, with an increase of care quality.

\section{References}

1. Alexopoulos, G. S., Abrams, R. C., Young, R. C., \& Shamoian, C. A. (1988). Cornell scale for depression in dementia. Biological psychiatry, 23(3), 271-284.

2. Banks, M. R., \& Banks, W. A. (2002). The effects of animal-assisted therapy on loneliness in an elderly population in long-term care facilities. The Journals of Gerontology Series A: Biological Sciences and Medical Sciences, 57(7), M428-M432.

3. Bemelmans, R., Gelderblom, G. J., Jonker, P., \& de Witte, L. (2012a). Socially Assistive Robots in Elderly Care: A Systematic Review into Effects and Effectiveness. Journal of the American Medical Directors Association, 13(2), 114-120.e111.

4. $\quad$ Bemelmans, R., Gelderblom, G. J., Jonker, P., \& de Witte, L. (2012b). State of the Art in Socially Assistive Robots for Elderly Care. submitted.

5. Broekens, J., Heerink, M., \& Rosendal, H. (2009). Assistive social robots in elderly care: A review. Gerontechnology, 8(2), 94-103. doi: 10.4017/gt.2009.08.02.002.00

6. Butter, M., Rensma, A., Boxtel, J. v., Kalisingh, S., \& and others. (2008). Robotics for Healthcare, Final Report: TNO, commissioned by the European Commission, DG Information Society.

7. Eisses, A. M. H., \& Kluiter, H. (2002). The 28-item version of the Behavior Rating Scale for Psychogeriatric Inpatients (GIP-28) for use in residential homes: A psychometric evaluation. Tijdschrift voor gerontologie en geriatrie, 33(3), 112-118.

8. Feil, N. (1989). Validation: An empathic approach to the care of dementia. Clinical Gerontologist: The Journal of Aging and Mental Health, 8(3), 89-94.

9. James, I. A., Mackenzie, L., \& Mukaetova-Ladinska, E. (2006). Doll use in care homes for people with dementia. International journal of geriatric psychiatry, 21 (11), 1093-1098.

10. Kidd, C. D., Taggart, W., \& Turkle, S. (2006). A sociable robot to encourage social interaction among the elderly. Paper presented at the Robotics and Automation, 2006. ICRA 2006. Proceedings 2006 IEEE International Conference on. 


\section{CHAPTER 4}

11. Kiresuk, T. J., \& Sherman, R. E. (1968). Goal attainment scaling: A general method for evaluating comprehensive community mental health programs. Community Mental Health Journal, 4(6), 443-453. doi: 10.1007/bfo1530764

12. Libin, A. V., \& Libin, E. V. (2004). Person-robot interactions from the robopsychologists' point of view: the robotic psychology and robotherapy approach. Proceedings of the IEEE, 92(11), 1789-1803.

13. Schnelle, W., \& Stoltz, I. (1987). The metaplan method: Communication tools for planning learning groups. Goethestrasse, Germany.

14. Tamura, T., Nakajima, K., Nambu, M., Nakamura, K., Yonemitsu, S., Itoh, A., . . Uno, H. (2001). Baby dolls as therapeutic tools for severe dementia patients. Gerontechnology, 1(2), $111-118$.

15. Tamura, T., Yonemitsu, S., Itoh, A., Oikawa, D., Kawakami, A., Higashi, Y., . . Nakajima, K. (2004). Is an Entertainment Robot Useful in the Care of Elderly People with Severe Dementia? Journals of Gerontology - Series A Biological Sciences and Medical Sciences, 59(1), $83-85$.

16. Tapus, A., Tapus, C., \& Mataric, M. J. (2009). The use of socially assistive robots in the design of intelligent cognitive therapies for people with dementia. Paper presented at the Rehabilitation Robotics, 2009. ICORR 2009. IEEE International Conference on.

17. Wada, K., Shibata, T., Musha, T., \& Kimura, S. (2008). Robot therapy for elders affected by dementia. Engineering in Medicine and Biology Magazine, IEEE, 27(4), 53-60.

18. Wada, K., Shibata, T., Saito, T., \& Tanie, K. (2002). Effects of robot assisted activity for elderly people at day service center and analysis of its factors. Paper presented at the Intelligent Control and Automation, 2002. Proceedings of the 4 th World Congress on.

19. Wessels, R., de Witte, L., Andrich, R., Ferrario, M., Persson, J., Oberg, B., . . Lorentsen, Ã. (2000). IPPA, a user-centred approach to assess effectiveness of assistive technology provision. Technology \& Disability, 13(2), 105-115. 


\section{How to use robot interventions in intramural psychogeriatric care: A feasibility study}

This chapter was published as:

Bemelmans R, Gelderblom GJ, Jonker P, de Witte L. How to use robot interventions in intramural psychogeriatric care; A feasibility study. Applied Nursing Research 2015. DOI: 10.1016/j.apnr.2015.07.003. 


\section{CHAPTER 5}

\section{Abstract}

Social robots, with Paro being an example, offer new opportunities for innovative approaches in dementia care. The objective of this study was to investigate how interventions, with the socially assistive robot Paro, can be implemented in daily care practice. Paro was used according to individualised interventions, aiming at predefined specific care problems, during a three week period. Selected residents, from small scale care units (8-10 residents each) in three Dutch care institutions for intramural psychogeriatric care, were offered Paro ones or twice a week. A total of 23 dementia patients, 22 female and 1 male, participated. Three intervention types were applied, one for therapeutic purposes, one for facilitating daily care activities and one to support social visits. The experience of care staff, informal caregivers and patients with Paro were registered qualitatively by means of a registration form in which each occasion of Paro use was briefly reported. Additionally, care staff was interviewed using a semi-structured qualitative questionnaire. The 23 residents were involved in 36 individually defined interventions, and in total 71 sessions were carried out. In the majority of cases, care staff and patients considered the Paro interventions to be of added value for the care provided. The use of Paro can be well individualised to the needs of patients, the resulting individual Paro intervention can be well implemented in day to day care and Paro may have added value when used in a well-directed way. 


\section{Introduction}

Psychogeriatric care for patients with dementia in the Netherlands is traditionally provided by professional caregivers in combination with informal caregivers. With the increasing incidence of dementia and the societal demand for cost reduction in care in general, a need grows for innovative care concepts to sustain and preferably improve the quality of psychogeriatric care. Technology is widely regarded as an important potential for such care innovation ${ }^{1}$. ICT technology and robotics are under rising attention of innovators ${ }^{2}$. The application of robotics seems particularly successful in the form of socially assistive robotics for which patients with dementia are often seen as a potential beneficiary group ${ }^{3,4}$. But, as most assistive robotic developments, the implementation of socially assistive robots is, after the technical development of the robot system, a major hurdle on the route to application of the robot in day to day care practice ${ }^{5}$. As the robot systems are developed to function close to patients and their caregivers, where the robots are supposed to support everyday care provision, it is essential that the use of the robot fits seamlessly into the established care provision practice. To facilitate this, the robot by itself should be seen as a mere starting point for care innovation. When it is to be applied as an instrument supporting psychogeriatric care there should be an intervention surrounding the robot, specifying usage, users and purpose of the robot application in such a way that caregivers are guided in putting the robot to effective use and can regard the robot as an instrument in their care provision rendering added value for their clients and their efforts ${ }^{6}$.

This study sets out to develop specific intervention for psychogeriatric care involving the socially assistive robot Paro ${ }^{7,8}$.

Three types of interventions were developed in close collaboration with four Dutch care institutions for elderly care ${ }^{6}$. These three interventions aim at:

1. Therapeutic purposes: depending on individual needs Paro can stimulate perception, psychological functioning, psychosocial well-being and social behaviour.

2. Facilitating daily care activities, making use of the attention focused on Paro or its comforting ability when made available. 


\section{CHAPTER 5}

3. Supporting social visits: the activating qualities of Paro on the patient could be used to provide a shared focus point for both the patient and family member(s) and stimulate the attractiveness of visits.

This paper reports on a study in which these three different types of interventions with Paro are applied in three different psychogeriatric care facilities. The Paro interventions were applied to individual patients translating one of the above mentioned aims into individualised goals in line with therapeutic or care related aims formulated for these individuals by the care professionals.

The aim of this study was to investigate how the interventions can best be implemented in daily care practice, and what the experiences of care staff, informal caregivers and patients are when doing so. In addition we wanted to evaluate the experienced added value of these interventions.

\section{Methods}

The study was executed in three Dutch care institutions for psychogeriatric care: Sevagram, located in Heerlen, with a total of 2500 employees; Proteion, located in Horn, employing 1400 care professionals; Dignis, located in Zuid Laren, employing 4500 care professionals. All three offer both intramural and extramural elderly care, including psychogeriatric care and somatic care. In each organisation, local small scale care units (8-10 residents each) were selected by the organisations for this study.

\section{Procedure}

As Paro was new to all care staff, the first step in the study was providing a brief training of care staff of the involved care units to familiarize them with the robot, its purpose and foreseen application. The training included one meeting and a two week period in which staff had the opportunity to familiarise themselves with Paro by means of hands on experience and an internet based training module containing written material and video instructions. For the practical application of the Paro interventions, a procedure was developed leading to clarification on which residents would be involved in the study and for what purposes. The procedure was developed such that it matches the process followed in providing day to day care to the resi- 
dents. For each of the selected residents a personal goal was specified by the responsible multidisciplinary team within one of the three intervention types formulated. For example: Mrs. A was selected as a suitable participant on the basis of the problematic behaviour she displays when making regular visits to the pedicure. Two care staff members usually have to accompany Mrs. A to enable the pedicure to perform her services. The goal of involving Paro would be to facilitate the visit and to make it possible without the accompanying care staff.

After the selection of the residents by the multidisciplinary team, approval was sought for each participant by the legal representatives. In accordance with Dutch legislation ${ }^{9}$ signed informed consent by the legal representatives of the participants gave way to inclusion of residents in the study.

To monitor the success of using Paro, assessment tools were selected involving assessment by staff members of the impact of the use of Paro on the selected aims at an individual level. Following the selection of participants and preparation of the assessment instruments, Paro was used with the selected residents according to the individualised interventions during a three week period. Prior to the actual use of Paro a baseline measurement was taken. This baseline measurement concerned observation of the problematic behaviour of each individual and the usual solution care staff would offer in this situation. After the use of Paro, involved care staff completed the assessment tool. By means of an interview the reports written down in the assessment forms were discussed, to ensure understanding of the material by the researcher. During the interventions aiming at social visits a care provider observed the interaction and completed the outcome instrument in consultation with the involved family members.

Following the period of data collection and analyses, a de-briefing meeting was organized with family members and the participating care staff in order to share experiences and inform them about the results of the study. The whole process involved both design and execution of the Paro intervention procedure. Table 1 shows an overview of the consecutive steps carried out in this study. 
Table 1. Chronologic Steps in the Execution of the Study

\begin{tabular}{|c|c|c|c|}
\hline Phase & \multicolumn{2}{|c|}{ Step } & \multirow{2}{*}{$\begin{array}{l}\text { Purpose } \\
\text { Introducing the pilot and blended } \\
\text { learning course. }\end{array}$} \\
\hline $\begin{array}{l}\text { Training of care } \\
\text { staff }\end{array}$ & 1 & $\begin{array}{l}\text { Kick-off meeting with care } \\
\text { providers }\end{array}$ & \\
\hline & 2 & Blended learning course & $\begin{array}{l}2 \text { weeks course. Introducing Paro } \\
\text { and explore its practical usage and } \\
\text { possible applications. }\end{array}$ \\
\hline & 3 & Pre-selection of participants & $\begin{array}{l}\text { Pre-selection of participants by care } \\
\text { providers, after the learning course. }\end{array}$ \\
\hline & 4 & Closing meeting & $\begin{array}{l}\text { Sharing experiences and discussing } \\
\text { possible Paro applications. }\end{array}$ \\
\hline \multirow[t]{5}{*}{$\begin{array}{l}\text { Selections of } \\
\text { participants }\end{array}$} & 5 & $\begin{array}{l}\text { Selection of participating } \\
\text { care providers }\end{array}$ & $\begin{array}{l}\text { Selection of participating care } \\
\text { providers, lead nurses, by the team } \\
\text { leaders, based on preferences after } \\
\text { the learning course. }\end{array}$ \\
\hline & 6 & Selection of patients & $\begin{array}{l}\text { Selection of patients by the team } \\
\text { leaders, based on the pre-selection } \\
\text { by the care providers. }\end{array}$ \\
\hline & & $\begin{array}{l}\text { Formulating intervention } \\
\text { goals }\end{array}$ & $\begin{array}{l}\text { Description of intervention goals } \\
\text { per patient, by the multidisciplinary } \\
\text { care team. }\end{array}$ \\
\hline & 7 & Briefing of family members & $\begin{array}{l}\text { Informing the family members of } \\
\text { selected patients about the pilot and } \\
\text { obtaining informed consent. }\end{array}$ \\
\hline & 8 & Work schedule planning & $\begin{array}{l}\text { Time table, composed by team } \\
\text { leaders, scheduling care providers, } \\
\text { patients, interventions, time and } \\
\text { place. }\end{array}$ \\
\hline $\begin{array}{l}\text { Conducting } \\
\text { interventions }\end{array}$ & 9 & Briefing with care providers & $\begin{array}{l}\text { Informing care providers about } \\
\text { intervention goals, usage of } \\
\text { measurement instruments, } \\
\text { work schedule and practical } \\
\text { arrangements. }\end{array}$ \\
\hline
\end{tabular}




\begin{tabular}{lll}
\hline Phase & Step & Purpose \\
\hline 10 & Baseline measurement & $\begin{array}{l}\text { Describing patients behaviour } \\
\text { before Paro application. }\end{array}$ \\
\hline 11 & Paro interventions & $\begin{array}{l}3 \text { weeks application of Paro } \\
\text { interventions. }\end{array}$ \\
\hline 12 & Questionnaires & $\begin{array}{l}\text { Re-assess the reported effects and } \\
\text { assess the practicalities involved in } \\
\text { applying Paro. }\end{array}$ \\
\hline
\end{tabular}

\section{Interventions}

Each intervention description contained a target group description, a description of the context and the application, and the type of outcomes and suitable outcome assessment tools. For the application of these interventions on an individual level a specification of the intervention is required, making the aim of the application valid for the individual, having a problematic behaviour or care problem of the individual explicated as a reason for introducing Paro. This provides a clear target for the use of Paro for each individual.

\section{Individual use of Paro}

In total 23 residents were considered for inclusion in this study. Selected residents would be offered Paro following the aims identified for each individual within one of the intervention types, ones or twice a week during three weeks. The duration of Paro use at each of these occasions typically would be $10-15$ minutes.

In case individual residents would obviously decline Paro, the interaction with Paro would be immediately stopped and reported as such. When this would be considered a temporal refusal a new attempt would be made later, following the original schedule. However, when this refusal was considered to be a definite viewpoint of the resident no further attempts would be undertaken to have this resident interact with Paro. These decisions had to be made by the first responsible care provider, who would notify the researcher. Care staff introduced Paro to the residents in a 
manner described in a work protocol. Also the role of the staff member during Paro use and completion of each Paro interaction was described in this protocol.

\section{Assessment of added value}

The experiences of care staff, informal caregivers and patients were registered qualitatively by means of a registration form in which each occasion of Paro use was briefly reported. For each of the Paro interactions the caregiver filled out a registration form describing the behaviour of the patient just before the intervention started, the reaction of the patient at the moment Paro was offered, the behaviour of the patient during the interaction with Paro, the behaviour and reaction of the patient at ending the intervention, and the perception of the caregiver regarding the added value of this session.

After the three week period, care staff was interviewed using a semi-structured qualitative questionnaire, to re-assess the effects as reported in their descriptions and to assess the practicalities involved in applying the Paro interventions and the experienced effects on the patients.

For each intervention the registration forms were collected and the information was, per intervention, aggregated by the researchers. The researchers then rated the qualitative data, in terms of practical applicability and experienced added value, on a 5-point ordinal scale. The researchers (i.e. the authors RB, GJG and LdW) based, in a joint meeting, the practical applicability and experienced added value on the registration forms and the interviews, thus transforming the reported experiences of the care providers to a 5-point scale. This rating, together with the aggregated information, was reported back to the participating care providers for validation and, based on their feedback, adjusted.

\section{Results}

A total of 23 patients, 22 female and 1 male, participated. For each participating resident one care staff member could be assigned who initiated and evaluated the application of the Paro intervention for this patient. Some of the involved staff members were assigned to more than one participating resident, and for some 
residents more than one intervention was applied. At Sevagram 4 nurses and 6 residents were involved, at Proteion 6 nurses and 7 residents and 5 family members were involved and at Dignis 6 nurses, 10 residents and 3 family members.

The 23 residents were involved in 36 individually defined interventions, and in total 71 sessions were carried out. The therapeutic intervention was most frequently applied ( 45 sessions in 21 residents), followed by the social visit intervention ( 14 sessions in 9 residents) and the care support intervention ( 12 sessions in 6 residents).

As the interventions were formulated in a highly individualised manner, each of the interventions in this study was evaluated separately. Table 2 shows the types of interventions, describes the problematic behaviour or care problem involved, and for each of the interventions the feasibility in terms of practical applicability and experienced added value is evaluated. The goals of the interventions were to reduce the problematic behaviours and so facilitating the care provision as defined in the description column of table 2 . This evaluation is based upon the registration forms and interviews. The researchers converted the data from these sources into a 5-point rating scale $(--,-, \mathrm{O},+,++)$. For 22 interventions the involved caregivers were positive about the added value, for 2 interventions they were negative and for 11 interventions they were neutral. For the practical applicability the caregivers gave a positive score for 26 interventions, a negative score for 4 interventions and a neutral score for 5 interventions. Also a strong correlation between added value and practical applicability is also visible. The therapeutic related interventions seem to be the most promising interventions, the feasibility of 17 out of 19 interventions was rated positive. For the care support related interventions 3 out of 7 interventions were rated positive and for the interventions aiming at socials visits 6 out of 9 were positive.

The interventions could all be executed by the caregiver involved, with the exception of 1 intervention, due to the participant's illness (this intervention is therefore not listed in table 2). In 2 cases the care providers chose to withdraw the participant, due to the rejection of Paro. In 2 other cases family members chose to stop participating, due to (observed) discomfort in their family member when interacting with Paro. Planned interventions were sometimes skipped due to practical reasons, i.e. the caregivers workload, the availability of Paro or the absence of the problematic behaviour during the presence of the selected caregiver. 
Table 2. Listing of Applied Interventions and Evaluation of their Feasibility, in terms of Practical Applicability and Experienced Added Value

\begin{tabular}{|c|c|c|c|c|c|}
\hline \# & Type & Description & Problematic behaviour & $\begin{array}{l}\text { Added } \\
\text { value }\end{array}$ & $\begin{array}{c}\text { Practical } \\
\text { applicability }\end{array}$ \\
\hline 1 & $\mathrm{C}$ & Wheelchair transport & $\begin{array}{l}\text { Fear and crying during } \\
\text { wheelchair transport }\end{array}$ & o & o \\
\hline 2 & C & $\begin{array}{l}\text { Physical care, } \\
\text { washing and dressing }\end{array}$ & $\begin{array}{l}\text { Fear and shame, resulting in } \\
\text { pinching, crabbing, crying and } \\
\text { screaming }\end{array}$ & + & + \\
\hline 3 & $S$ & Making contact & $\begin{array}{l}\text { Distracted and limited interaction } \\
\text { with visitor (husband) }\end{array}$ & + & o \\
\hline 4 & $\mathrm{~T}$ & Sit still & $\begin{array}{l}\text { Urge to walk or wander, with risk } \\
\text { of falling }\end{array}$ & ++ & ++ \\
\hline 5 & $S$ & Sit still & $\begin{array}{l}\text { Urge to walk or wander during } \\
\text { visits }\end{array}$ & ++ & + \\
\hline 6 & $\mathrm{~T}$ & Activation & Remains in bed & ++ & ++ \\
\hline 7 & $S$ & Activation & Quiet and minimal interaction & ++ & + \\
\hline 8 & $\mathrm{~T}$ & Relaxation & $\begin{array}{l}\text { Emotions of fear, unrest and } \\
\text { shouting }\end{array}$ & ++ & ++ \\
\hline 9 & C & Pedicure & Restless and repulsive behaviour & ++ & + \\
\hline 10 & $\mathrm{~S}$ & Conversation & Word finding difficulties & + & ++ \\
\hline 11 & $\mathrm{~T}$ & Activation & Physical inactivity & -- & + \\
\hline 12 & $S$ & Conversation & Minimal interaction & -- & o \\
\hline 13 & $\mathrm{~T}$ & Activation & Passive and dreamy & + & ++ \\
\hline 14 & $S$ & Conversation & Minimal interaction & + & + \\
\hline 15 & $\mathrm{~T}$ & Activation & Passive and dreamy & ++ & ++ \\
\hline 16 & $\mathrm{~T}$ & Activation & Quiet and minimal interaction & o & + \\
\hline
\end{tabular}




\begin{tabular}{|c|c|c|c|c|c|}
\hline \# & Type & Description & Problematic behaviour & $\begin{array}{l}\text { Added } \\
\text { value }\end{array}$ & $\begin{array}{c}\text { Practical } \\
\text { applicability }\end{array}$ \\
\hline 17 & $\mathrm{~T}$ & Liven up & Somber and introverted & ++ & ++ \\
\hline 18 & $\mathrm{~T}$ & Liven up & Sequestered and quiet & ++ & ++ \\
\hline 19 & $\mathrm{~T}$ & Liven up & Depressive & + & ++ \\
\hline 20 & $\mathrm{~T}$ & Relaxation & Unrest and shouting & o & + \\
\hline 21 & $\mathrm{~T}$ & Relaxation & Unrest and shouting & + & + \\
\hline 22 & $S$ & Conversation & Word finding difficulties & + & + \\
\hline 23 & $\mathrm{~T}$ & Relaxation & Shouting, repulsive and restless & + & ++ \\
\hline 24 & $\mathrm{~T}$ & Activation & Passive, minimal interaction & + & ++ \\
\hline 25 & $\mathrm{~T}$ & Activation & Minimal interaction & o & + \\
\hline 26 & C & $\begin{array}{l}\text { Physical care, } \\
\text { washing and dressing }\end{array}$ & Restless and repulsive behaviour & o & -- \\
\hline 27 & $S$ & Making contact & Absent and introvert & o & - \\
\hline 28 & $\mathrm{~T}$ & Distraction & Verbal aggression & o & - \\
\hline 29 & $\mathrm{~T}$ & Relaxation & Unrest, ill-tempered & ++ & + \\
\hline 30 & $\mathrm{~T}$ & Making contact & Introvert, limited interaction & + & + \\
\hline 31 & C & Transfer & Fear and unrest & ++ & + \\
\hline 32 & C & Pedicure & Repulsive & o & o \\
\hline 33 & C & $\begin{array}{l}\text { Physical care, } \\
\text { dressing }\end{array}$ & Repulsive & o & -- \\
\hline 34 & $\mathrm{~T}$ & Making contact & Bedridden, loneliness & o & + \\
\hline 35 & $\mathrm{~S}$ & Conversation & Limited interaction with visitors & o & o \\
\hline
\end{tabular}

Type: $T=$ Therapeutic, $C=$ Care Support, $S=$ Social Visit 
In executing the study scheduling issues occurred in terms of the availability of the selected caregivers related to the occurrence of the problematic behaviour (i.e. the aim of the intervention). Practical issues concerning the location and storage of the registration forms and the Paro robot (including battery charging) also occurred.

The registration forms and the interviews with the caregivers showed that in the majority of cases the Paro interventions were considered to be of added value for the care provided. Caregivers experienced problems with the administration of the sequence of Paro encounters and the evaluations that were to be made. The interventions aiming at therapeutic effects could easily be combined with the daily care activities. However, during the interventions that aimed at supporting care, the caregivers experienced difficulties in providing daily care and at the same time encouraging interaction with Paro. Although this was not the main aim of this study, caregivers reported mostly positive to very positive outcomes of the interventions for the residents. On the basis of these positive outcomes, in combination with the practical feasibility, caregivers and residents showed enthusiasm to continue using Paro for the formulated purposes.

\section{Discussion}

The aim of the study was to investigate how Paro interventions can be implemented in institutional psychogeriatric elderly care practice and to evaluate the experiences of care staff, informal caregivers and patients when doing so. Three types of Paro interventions were developed and in this study made explicit by formulation of individualised Paro interventions for 23 residents. All these interventions were put to practice in three psychogeriatric care homes and both the application in practice was evaluated as well as the assessment of the added value on an individual level.

Of the added value of the application of Paro in psychogeriatric care no clear picture was available in the literature. Care workers were initially not at ease with the inclusion of Paro in their daily work. The procedure developed and applied in this study aimed at formulating explicit and individualised interventions aiming at specific care problems. By doing so the intended effects of the use of Paro for each participating individual was made both clear and measurable. It clarified what care workers could do with Paro and what to expect from its use. Moreover it demon- 
strated the practical feasibility of the procedure and gave insight into the added value of Paro for individual residents.

The intervention aimed at supporting family visits seems to be least feasible, partly due to unfamiliarity with the robot and uncertainty about the effects, but mostly because of experienced discomfort reported by the visiting family.

Caregivers and family members need to be well informed about the purpose and practical course of the interventions. In advance there was quite a bit of resistance or skepticism towards using a social robot, but once used this resistance often turned into enthusiasm. Ethical issues were raised but also issues concerning hygiene and possible side effects like sadness after ending the session with Paro.

In order to evaluate the use and added value of Paro a detailed time-table and work-schedule is needed, describing the relation between patient, care professional, time, place and intervention goal. Clear descriptions of the intervention goals per patient need to be formulated, otherwise Paro is used in a way not relating the intervention goals.

In the literature reports on the effect of Paro are scarce and, when available, the rationale behind the procedure applied and the goals for using Paro are not reported ${ }^{5}$. In this study this relation was made very explicit and by doing so provide a rationale for applying Paro for individual users.

The reported positive evaluation of the use of Paro suggest that a solid study into the (cost-)effectiveness is worthwhile.

\section{Conclusion}

This study shows that, when used in an individualised and targeted way, Paro offers interesting potential for psychogeriatric elderly care. Using Paro in this care setting is feasible and very promising. 


\section{References}

1. Butter, M., Rensma, A., Boxtel, J. v., Kalisingh, S., \& and others. (2008). Robotics for Healthcare, Final Report: TNO, commissioned by the European Commission, DG Information Society.

2. Butter, M., Boxtel, J. v., Kalisingh, S., Gelderblom, G. J., \& and others. (2007). Robotics for Healthcare, State of the art report: TNO, commissioned by the European Commission, DG Information Society.

3. Broekens, J., Heerink, M., \& Rosendal, H. (2009). Assistive social robots in elderly care: A review. Gerontechnology, 8(2), 94-103. doi: 10.4017/gt.2009.08.02.002.00

4. Tapus, A. (2009). Improving the Quality of Life of People with Dementia through the Use of Socially Assistive Robots. Paper presented at the Advanced Technologies for Enhanced Quality of Life, 2009. AT-EQUAL 'o9.

5. Bemelmans, R., Gelderblom, G. J., Jonker, P., \& de Witte, L. (2012). Socially Assistive Robots in Elderly Care: A Systematic Review into Effects and Effectiveness. Journal of the American Medical Directors Association, 13(2), 114-120.e111.

6. Bemelmans, R., Gelderblom, G. J., Spierts, N., Jonker, P., \& de Witte, L. (2013). Development of robot interventions for intramural psychogeriatric care. GeroPsych: The Journal of Gerontopsychology and Geriatric Psychiatry, 26(2), 113-120. doi: 10.1024/1662-9647/a000087

7. Shibata, T., Wada, K., Saito, T., \& Tanie, K. (2004). Robotic Therapy at an Elderly Institution using a Therapeutic Robot. Annual Review of CyberTherapy and Telemedicine, 2, 125-136.

8. Wada, K., Shibata, T., Asada, T., \& Musha, T. (2007). Robot therapy for Prevention of Dementia at Home. Journal of Robotics and Mechatronics, 691-697. 9. Dute, J. C. J., Friele, R. D., Nys, H., Brink, V. A. J. o. d., Gils, R. C. W. v., Eysink, P. E. D., \& Hanssen, J. E. (2004). Evaluatie Wet Medisch-Wetenschappelijk Onderzoek met mensen: ZonMw.

9. Dute, J. C. J., Friele, R. D., Nys, H., Brink, V. A. J. o. d., Gils, R. C. W. v., Eysink, P. E. D., \& Hanssen, J. E. (2004). Evaluatie Wet Medisch-Wetenschappelijk Onderzoek met mensen: ZonMw. 


\section{Effectiveness of robot Paro in intramural psychogeriatric care: A multicenter quasi-experimental study}

This chapter was published as:

Bemelmans R, Gelderblom GJ, Jonker P, de Witte L. Effectiveness of robot Paro in intramural psychogeriatric care: A multicenter quasi-experimental study. Jamda: Journal of the American Medical Directors Association 2015. DOI: 10.1016/j. jamda.2015.05.007. 


\section{CHAPTER 6}

\section{Abstract}

Together with care professionals, specific psychogeriatric care applications were developed for the seal robot Paro. The objective of this study was to evaluate the outcomes of the developed Paro interventions, applying the robot in psychogeriatric care. A multicenter quasi-experimental time series $A B A B$ study $(n=91)$ with within-subject comparison was conducted to assess both the short-term effects of the Paro interventions for therapeutic applications, and the facilitation of daily care activities by care providers. Participants were selected from small-scale care units (8 - 10 residents each), spread over 6 different locations, in 3 Dutch care institutions for intramural psychogeriatric care. A total of 91 patients with dementia, in all stages of dementia. Two user-centered intervention types were applied, one for therapeutic purposes and one for the facilitation of daily care activities. Effectiveness was measured with a goal attainment scale (IPPA) and a mood scale (Coop/Wonca), by means of a registration form. A total of 106 user-specific interventions were defined for 91 participants; 71 participants completed the study, 14 were men and 57 were women. All interventions combined show a significant effect $(p<.001)$. Paro should be seen as a tool for care staff and not as a replacement of care. Successful implementation of Paro in daily intramural psychogeriatric care practice can increase the quality of care and the quality of life for the elderly. 


\section{Introduction}

The ongoing development of technology is seen as having vast potential for the provision of care. Technologies such as ICT and robotics make innovative applications possible that may facilitate caregivers in their work. The rapid development of "social" user interaction software implemented in robots makes application of care robots for social purposes attainable ${ }^{1,2}$. Within the domain of socially assistive robotics (SAR) at least 25 systems have become available in recent years ${ }^{3}$. Literature reviews revealed that little is known about the effects of these systems in healthcare ${ }^{4,5}$. The application of SAR and certainly their effects in elderly care have not been studied comprehensively and very few academic publications can be found.

Paro is a socially assistive seal robot, specifically designed for psychogeriatric care, with 5 types of sensors: tactile, light, audio, temperature, and posture, with which it can perceive people and its environment. It can respond to stimuli, perceived by its sensors, by making noise, moving its eyes, head and flippers ${ }^{6,7}$.

In this study the embedding of robot innovations in daily care practice is studied. Together with care professionals, specific psychogeriatric care applications were developed for Paro ${ }^{8}$. These applications, further called interventions, define the use of the robot for its target population(s) in care provision. The intention of the intervention is specified in terms of the intended effect or the expected added value off using the system. Information or/and instructions for both care receivers and providers had been made available. Without the context of an intervention it is highly likely that the application of the robot in care will be seen as an entertaining gadget only.

This study aims at evaluating the outcomes of two of the previously developed Paro interventions ${ }^{8}$, applying the robot in psychogeriatric care (Picture 1). Making Paro interventions part of the daily care routine requires the formulation of individual care targets for each resident, which will be done within the two Paro interventions. The first intervention aims at therapeutic effects in providing comfort to individual distressed dementia patients in critical timeslots during the daily routine. Distress is a common symptom of dementia and may result in distorted activation patterns ${ }^{9}$. The second Paro intervention aims at facilitating the provision of daily care 


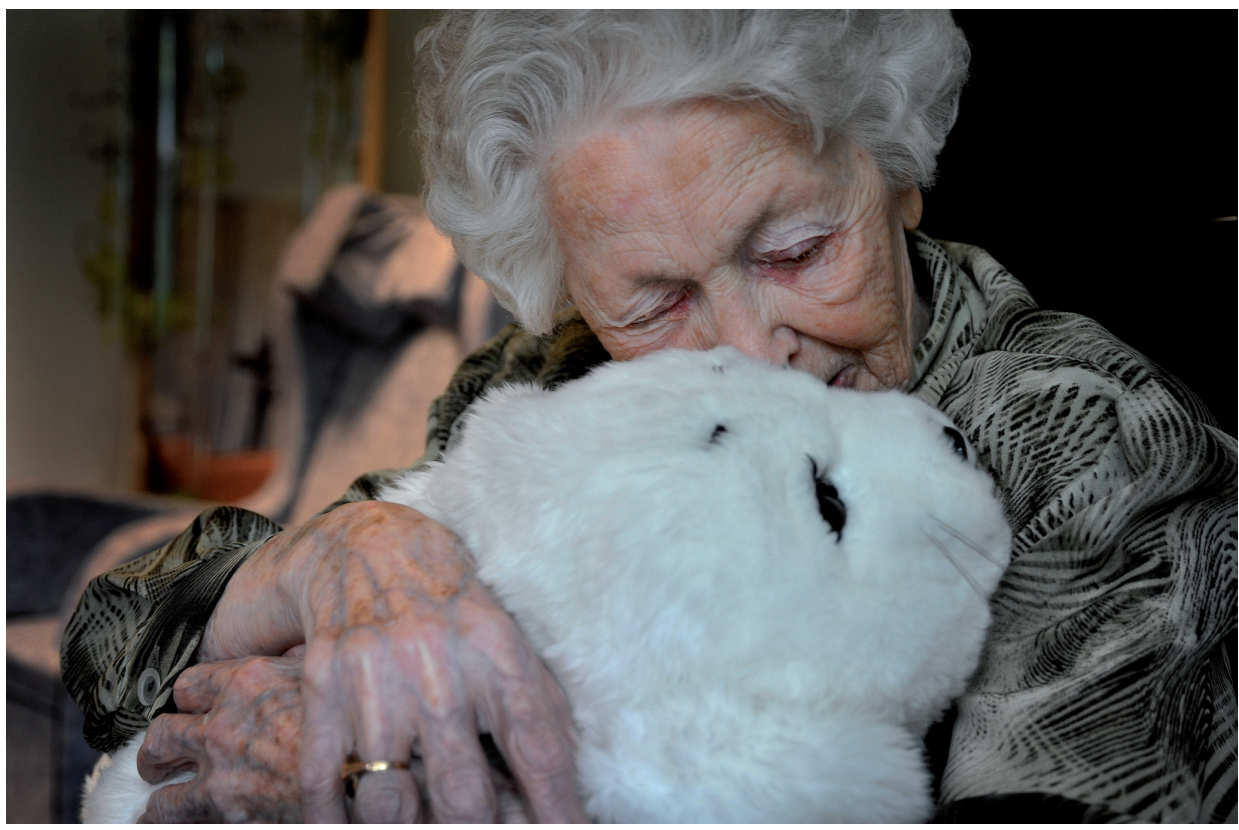

Picture 1. Example of Paro interacting with elderly resident

tasks by care staff. Paro could bring about a desired mindset of the patient, lowering common resistance to ADL care tasks executed by the staff, functioning as a diversion or as a means to bring about a more cooperative mood.

The main research question in this study is: are the developed interventions effective, when applied at an individual (i.e. user centered) level targeting the intended goals?

\section{Methods}

\section{Design}

We conducted a multi-center quasi-experimental time series ABAB study ( $n=91)$ with within-subject comparison. This study assessed both the short-term effects of the Paro interventions on psychological functioning and psychosocial well-being of patients, and the facilitation of daily care activities by care providers.

This study was approved by the Dutch governmental Medical Ethical Commission (METC), and is registered under number NL40271.096.12 
In the period May 2012 to October 2013 three Dutch psychogeriatric care providing organizations, i.e. Sevagram, Proteion and Orbis, participated in this multi-center study, spread over six different locations in Limburg, a southern province of the Netherlands. For each participant, the study had a duration of four months. To make this possible, the entire study had a duration of approximately 1.5 years. Per participant the study was divided into four consecutive phases (i.e. $A B A B$ ) of one month each.

The primary outcome was measured on an individual level by a care provider, based on the Individually Prioritized Problems Assessment (IPPA) score 10,11. A mood scale ${ }^{12}$ was used as secondary outcome, in order to validate that the reported effects by the care providers (i.e. IPPA score) were consistent with the resident's mood. As a reference, due to the progressive nature of dementia, a Dutch behavioral rating scale for geriatric inpatients ${ }^{13,14}$ was used before and after the interventions period.

In the first and third phase (i.e. A phases) the participants received usual care and were measured five times, based on the IPPA score and the mood scale, at moments corresponding to the interventions goals. In the second and fourth phase (i.e. B phases) the participants received the Paro interventions five times, also at moments corresponding to the interventions goals.

The sample size estimation was based on the Wilcoxon (non-parametric) signedrank test. Given an alpha of 0.05 and a power of $80 \%$, in order to achieve an effect size $<30 \%$, the sample size for a one-tailed test should be at least 74 participants. With an estimated dropout of 20 the initial sample size was determined at +90 .

\section{Participants}

Recruitment of participants took place via the three participating care organizations.

For the therapeutic intervention the following behaviors give some indication for criteria to select residents for which the intervention seems suitable: aggression (verbal - physical), physically tense, physically agitated, anxiety, picking, throwing objects, quiet (introverted), passive. An indication for the goals was: stimulating senses, getting attention, relaxation and rest. 


\section{CHAPTER 6}

For the care support intervention the following behaviors give some indication for criteria to select residents for which the intervention seems suitable: aggression (verbal - physical), physically tense, physically agitated. An indication for the goals was: focusing, relaxation and fear reduction.

Participants were eligible when: (1) they showed undesirable psychological or psychosocial unrest or mood, based on the professional judgment of the care providers; (2) the care providers experienced difficulties in providing ADL-care tasks. During a group session, psychologists, team leaders and lead nurses (nurses who were primarily responsible for certain patients) identified a number of pre-selected participants who could benefit from the developed interventions. These pre-selected participants were then discussed by the multidisciplinary team (MDO) responsible for the individual care plans of all residents, involving psychologists, psychiatrists, nurses and nursing home physicians. During this discussion some pre-selected participants were excluded, based on the professional judgment of the team. This was often due to medical (i.e. somatic or psychiatric) objections against participation or due to other conflicting interventions. Thus the final set of participants was formed. The MDO formulated the individual goals per participant and per intervention and defined these in terms of specific problematic behavior. Legal representatives of the eligible participants received an information letter. If no signed informed consent was obtained from the legal representatives, participants were excluded. Participants themselves or via their legal representatives, could leave the study at any time for any reason if they wished to do so, without any consequences. Rejection of the intervention, to be recognized by the care staff, had to be honored immediately whereupon the session had to be terminated smoothly. The medical team could further decide to withdraw a subject from the study for urgent medical reasons.

\section{Training of care staff}

The first step in the study was a kickoff meeting at each participating care organization to inform legal representatives, family members, care providers and team managers about the aim and procedure of the study. Following the kickoff meeting the local care providers participated in a 2 week training course, introducing Paro, the intervention protocols and its goals. 


\section{Intervention}

Each of the two interventions was described by a protocol that nurses should follow, wherein the course of the intervention was described in simple steps. This protocol was to be used in the context of the specified goals defined for the particular participant. At the onset of the targeted behavior (therapeutic application), or at the start of the care support activity, Paro was introduced by the care provider similar to the following text: "Look Mrs. / Mr. X, this is the seal Paro. He will sit with you for a while. You can stroke, cuddle or talk to him if you like. He can sit on your lap or stay on the table." During the activity Paro stayed on a table (or on their lap), so that the participant could interact with it. Paro tries to stimulate interaction and attracting attention from the participant by making enjoyment, by making soft noises and bowing its head towards the participant, thus reinforcing the interaction. The care provider was active in reminding the participant of the presence of Paro if necessary and stimulated interaction between the participant and Paro. At the end of the activity (after about 15 minutes) the session was ended smoothly by saying goodbye to Paro. The caregiver said e.g. "Paro, until next time. Would you also like to say something to Paro Mrs. / Mr. X?" Immediately following the intervention the care provider filled in the registration forms (i.e. IPPA and mood scale) and Paro was then stored at a pre-defined location.

\section{Data collection}

During each of the four phases, the behavior of the participants was measured 5 times based on the IPPA score. The IPPA is a goal attainment scale ${ }^{15}$ for describing several characteristics of a particular behavior; it was scored on a 5-point rating scale. In addition to the IPPA score, the primary outcome of this study, a 5-point mood scale ${ }^{12}$ was also used to measure psychological and psychosocial functioning during the intervention. This procedure lead, per participant, to 5 (observations) *2 (months) $=10$ measurements with intervention and 10 measurements without intervention. In between measurements the participants did not receive any Paro interventions. The measurement instrument used by the care providers included, in addition to the IPPA and the 5-point mood scale, the specific problematic behavior as defined by the MDO. This behavior specification aligns the focus 


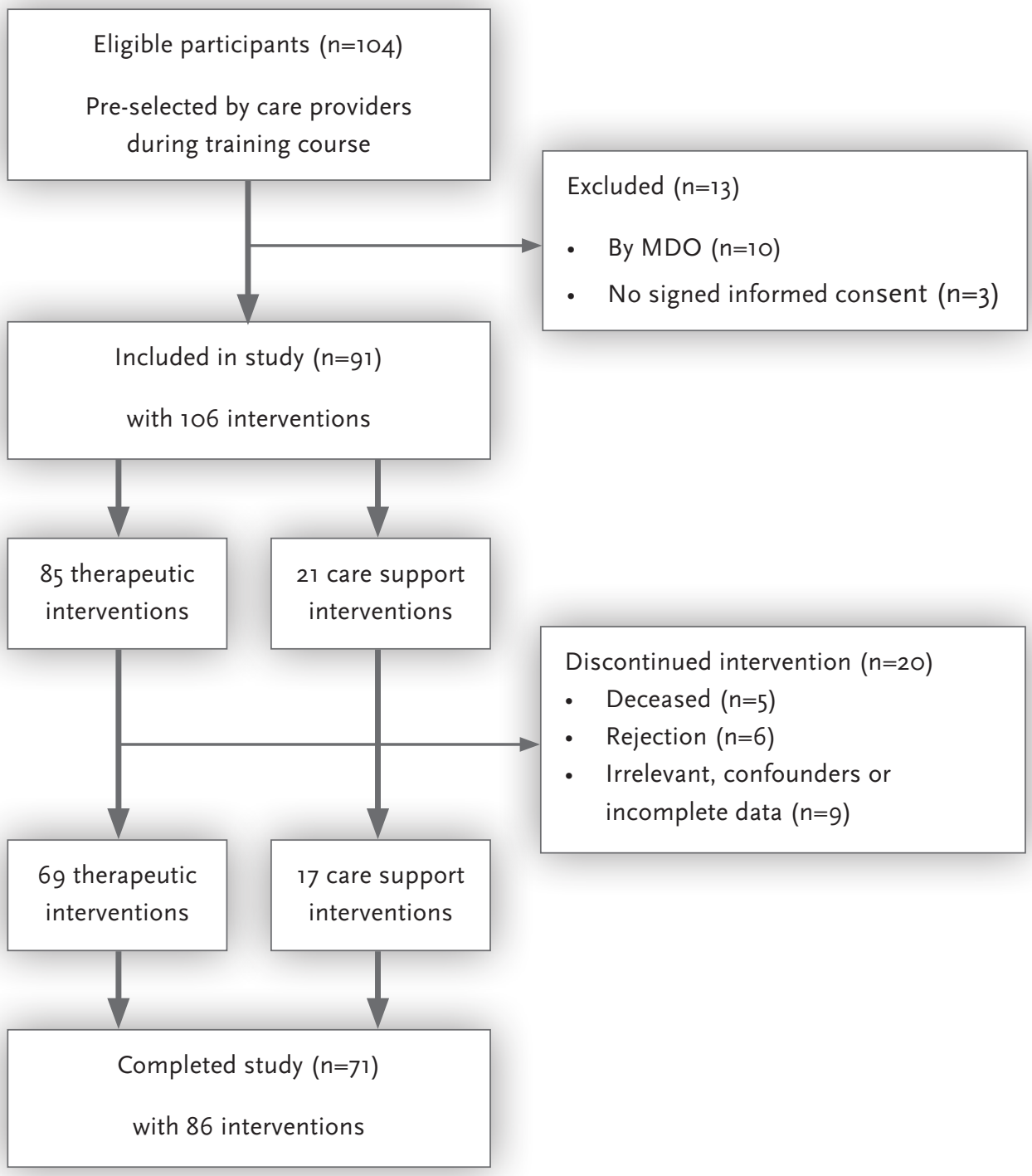

Figure 2. Flow of participants

of the care provider to the defined intervention goal. Given the subjective nature of the observations, each participant was paired with a single care provider during an $A B$ period, in order to obtain comparable results. 
To get insight in the dementia-phase of the participants, the Dutch GIP-28 scale was administered at the start and at the end of the studies, by the local psychologist, resulting in 2 GIP-28 scores per participant.

\section{Analysis}

For each intervention the average of the 5 IPPA scores per phase, in the ABAB design, was calculated. The difference between the average IPPA scores of each consecutive $A B$ phase (i.e. average IPPA score of phase $B$ minus average IPPA score of phase $A$ ) indicates the effect of the intervention. A difference of $o$ indicates no effect in terms of the intervention applied, a positive difference $(>0)$ indicates a positive effect of the intervention and a difference $<0$ indicates a negative effect of the intervention.

The Wilcoxon signed-rank test was used to determine whether differences are significant. The measurement variable is the average IPPA score, the primary outcome variable of this study, for each $A B A B$ phase per intervention. The estimator is the median difference between consecutive $A B$ phases.

\section{Results}

A total of 104 participants were pre-selected by the care providers during the training course. After the multidisciplinary team meetings, 94 participants received an informed consent form, of whom 91 signed the consent form. A total of 106 user specific interventions were defined for the 91 participants, 7 participants received both therapeutic and care support interventions, and 28 nurses participated in the interventions. In total 71 participants completed the study and 86 interventions were conducted; 17 regarding care support and 69 aiming at therapeutic effects. Figure 2 shows the flow of participants; 14 participants were male $(20 \%)$ and 57 participants (80\%) were female. Based on the GIP scores the majority of the participants were, evenly distributed, in the first stages of dementia. Only 6 participants were in the final stage of dementia. The GIP scores at the start $(11.3, S D=2.4)$ and at the end $(12.2, S D=2.7)$ of the study indicate a slight decline in overall functioning. 


\section{CHAPTER 6}

Figure 3 shows the effects of the interventions in terms of the differences between each consecutive $A B$ phase, on average per intervention.

The overall average IPPA difference, i.e. the average IPPA difference for all interventions, is 0.63 and the average difference in MOOD score is 0.54 . The correlation coefficient between the IPPA scores and the Mood scores is 0.68 , indicating that the direction of effects is consistent between different assessment tools. In figure 4 the average IPPA scores per phase and per intervention type are presented.

The effect was evaluated with the Wilcoxon signed-rank test. All interventions combined show a significant effect $(p<0.001)$, with an effect size $r=0.42$. Differentiating to intervention type, the therapeutic related interventions show a significant effect $(p<0.001)$, with an effect size $r=0.52$, where the care support related interventions do not show a significant effect $(p=0.58)$, with an effect size $r=0.03$.

The care support interventions have a negative result in the first $A B$ period followed by a positive result in the second $A B$ period. For the therapeutic interventions a significant effect is presented, for the care support interventions however no significant effect is shown.

\section{Discussion}

For the therapeutic interventions the effectiveness of Paro is clearly demonstrated. On a 5-point scale (IPPA and Mood score) the maximum difference is 4 , hence an average difference of 2 indicates a strong positive effect. The IPPA and Mood scores show a high correlation underlining the outcome.

Since no other large scale multi-centered study is published involving the use of Paro based on individually defined interventions $4,16,17$, these results stand on their own and cannot be compared with similar studies.

Because of the highly individual character of the interventions a comparison against a control group provided with a placebo or "therapy as usual" was discarded. The use of a placebo tool only gives insight into the differences between the intervention group and the specific placebo group, generalizing these differences has no grounding. 

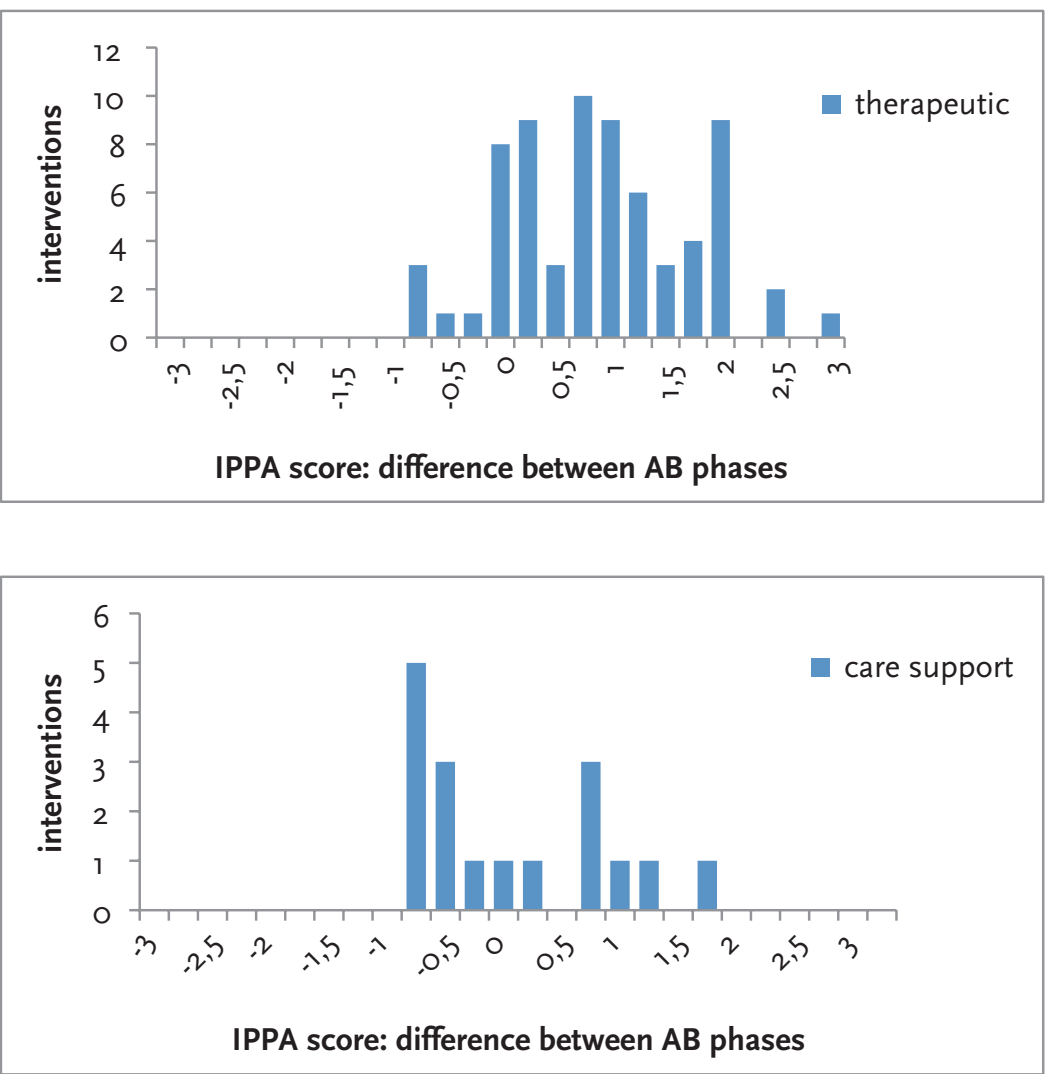

Figure 3. Participants average IPPA scores

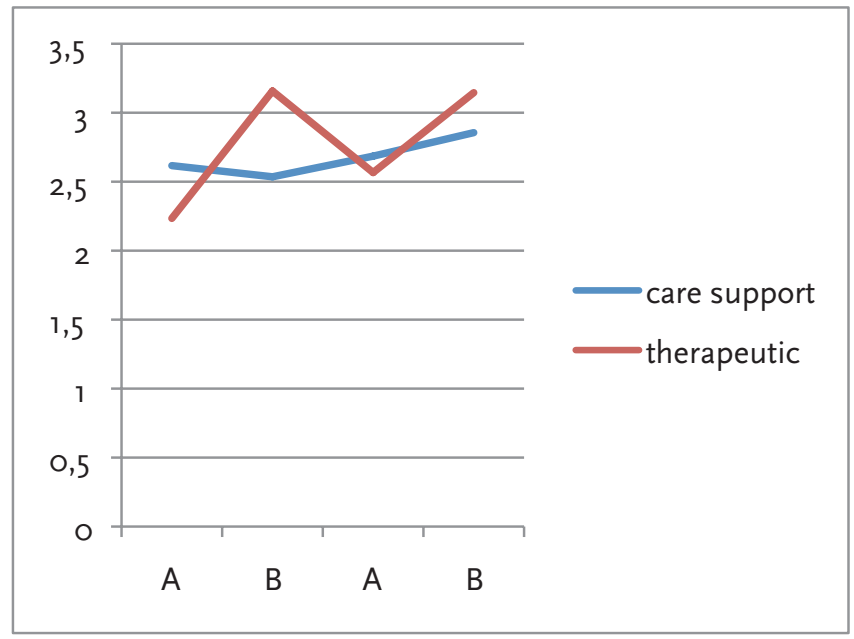

Figure 4. IPPA scores per $A B A B$ phase 


\section{CHAPTER 6}

Interviews with the caregivers involved give rise to the assumption that the use of Paro in care support interventions at first is experienced as an additional load on the caregivers. However, as the health care providers gain more experience in the use of Paro, in the context of care support, it seems to have a more positive effect. It should be noted, however, that this should be interpreted with caution due to the limited number of care support interventions. Additional research, taking into account the possible learning curve when applying Paro in a care support activity, is therefore needed in order to gain more insight into the effects and effectiveness of Paro in supporting care. Caregivers also noted that attention should be paid to hygiene if the robot is to be used by multiple residents and that in terms of practical use, storage of the robot and charging of the battery needs to be well organized and structured. We recorded some interviews with caregivers and family members on video, this video (https://www.youtube.com/watch?v=QvRAMAmOFGk\&feature) gives a nice impression of the field experiences with Paro interventions.

In order to get insight into the effects for subgroups (e.g. male and female), a subgroup analysis should be performed. Although no significant difference was observed between male and female participants and also no significant difference was observed in terms of effects compared to the dementia phase of the participants, these observations can only be seen as indications of possible effects. Due to the limited number of participants in this study for each subgroup no conclusive results can be presented for these subgroups.

In socially assistive robotics the technical demands are not the critical artefacts ${ }^{18}$, but the acceptance of the robot as added value in care practice is. An essential step in this process is sound assessment outcomes of care robotics in daily care provision ${ }^{19}$. Without such assessment reimbursement will become a problem, undermining the application and further development of socially assistive robotics. Follow up research is needed, to validate the primary results of this study (i.e. a positive effect of the therapeutic interventions) for various subgroups and to get more insight in the possible effects of care support interventions. 


\section{Effectiveness of Paro interventions}

\section{Conclusion}

This study shows that Paro is clearly effective for interventions aiming at a therapeutic effect, if applied in a well thought-out manner and tailored to the individual situation of the elderly. For each participant a user centered intervention was defined with a role for Paro, the participant and the caregiver. For interventions aiming at care support this study shows no significant effect.

Care organizations can use these results to embed robot technology, and Paro in particular, in their daily care provision with directions for the way Paro could be used. Paro should be seen as a tool for care staff and not as a replacement of care. Successful implementation of Paro in daily intramural psychogeriatric care practice can increase the quality of care and the quality of life for the elderly.

The reported success of the therapeutic interventions should be contributed to user centered interventions. Paro can be of great added value when applied in individually defined interventions. Moreover, the training of care staff prior to the use of Paro probably contributed to the effects.

It was a great encouragement that the care professionals involved where initially critical at the results to be expected at the outset of the study but turned into strong enthusiasts for the robot. They convinced their care organization to invest in over 20 Paro robots before completion of the study, to have one available for each PG ward.

\section{References}

1. Butter M, Rensma A, Boxtel Jv, Kalisingh S, and others. Robotics for Healthcare, Final Report. TNO, commissioned by the European Commission, DG Information Society;2008.

2. Bemelmans R, Gelderblom GJ, Jonker P, de Witte L. The Potential of Socially Assistive Robotics in Care for Elderly, a Systematic Review, Human-Robot Personal Relationships. In: Lamers MH, Verbeek FJ, eds. HRPR 2010. Vol 59: Springer Berlin Heidelberg; 2011:83-89.

3. Butter M, Boxtel Jv, Kalisingh S, Gelderblom G), and others. Robotics for Healthcare, State of the art report. TNO, commissioned by the European Commission, DG Information Society;2007. 


\section{CHAPTER 6}

4. Bemelmans R, Gelderblom G), Jonker P, de Witte L. Socially Assistive Robots in Elderly Care: A Systematic Review into Effects and Effectiveness. Journal of the American Medical Directors Association. 2012;13(2):114-120.e111.

5. Broekens J, Heerink M, Rosendal H. Assistive social robots in elderly care: A review. Gerontechnology. 2009;8(2):94-103.

6. Wada K, Shibata T, Asada T, Musha T. Robot therapy for Prevention of Dementia at Home. Journal of Robotics and Mechatronics. 2007:691-697.

7. Wada K, Shibata T, Musha T, Kimura S. Robot therapy for elders affected by dementia. Engineering in Medicine and Biology Magazine, IEEE. 2008;27(4):53-60.

8. Bemelmans R, Gelderblom G), Spierts N, Jonker P, de Witte L. Development of robot interventions for intramural psychogeriatric care. GeroPsych: The Journal of Gerontopsychology and Geriatric Psychiatry. 2013;26(2):113-120.

9. Alexopoulos GS, Abrams RC, Young RC, Shamoian CA. Cornell scale for depression in dementia. Biological psychiatry. 1988;23(3):271-284.

10. Wessels R, de Witte L, Andrich R, et al. IPPA, a user-centred approach to assess effectiveness of Assistive Technology provision. Technology and Disability. 2000;13(1):105-115.

11. Wessels R, Persson J, Lorentsen, et al. IPPA: Individually prioritised problem assessment. Technology and Disability. 2002;14(3):141-145.

12. Van Weel C. Functional status in primary care: COOP/WONCA charts. Disability and Rehabilitation. 1993;15(2):96-101.

13. Eisses $\mathrm{AMH}$, Kluiter $\mathrm{H}$. The 28-item version of the Behavior Rating Scale for Psychogeriatric Inpatients (GIP-28) for use in residential homes: A psychometric evaluation. Tijdschrift voor gerontologie en geriatrie. 2002;33(3):112-118.

14. De Jonghe J, Kat M, De Reus R. Validity of the Behavior Observation Scale for Intramural Psychogeriatrics: A comparison with the BOP (Evaluation Scale Elderly Patients) and NOSIE-30 in a psychogeriatric assessment clinic for the elderly. Tijdschrift voor Gerontologie en Geriatrie. 1994;25:110-116.

15. Kiresuk TJ, Sherman RE. Goal attainment scaling: A general method for evaluating comprehensive community mental health programs. Community Mental Health Journal. 1968;4(6):443-453.

16. Mordoch E, Osterreicher A, Guse L, Roger K, Thompson G. Use of social commitment robots in the care of elderly people with dementia: A literature review. Maturitas. 2013;74(1):1420.

17. Leite I, Martinho C, Paiva A. Social Robots for Long-Term Interaction: A Survey. International Journal of Social Robotics. 2013;5(2):291-308. 
18. Giusti L, Marti P. Interpretative Dynamics in Human Robot Interaction. Paper presented at: Robot and Human Interactive Communication, 2006. ROMAN 2006. The 15th IEEE International Symposium on2006.

19. Dautenhahn K. Methodology \& Themes of Human-Robot Interaction: A Growing Research Field. International Journal of Advanced Robotic Systems. 2007;4:103-108. 
General discussion 


\section{Discussion}

The main objective of this study was to develop and evaluate care interventions, using assistive social robots, focusing on intramural psychogeriatric care. Such robot-supported interventions can both support caregivers in their daily work and provide residents more quality of life. To develop such interventions we first examined the already published effects social robots can have in elderly care practice ${ }^{1}$. Next, the available robotic systems were investigated ${ }^{2}$. On the basis of the published effects and the available robotic systems, in close cooperation with a number of care providers, three different robot-supported interventions were defined ${ }^{3}$. The practical applicability of these interventions has been evaluated in a small pilot study ${ }^{4}$. Subsequently, in a large-scale quasi experimental study the effects of the interventions were investigated ${ }^{5}$.

In this chapter, the main findings of this research are presented. Also a reflection on the methodological aspects of this study is discussed. This research can provide a significant contribution to the improvement of well-being of patients, with an increase of care quality. The results can benefit care providers, patients and care financiers.

\section{Main findings}

\section{Published effects and effectiveness of robot interventions aiming at social assistance in elderly care.}

We searched, using Medical Subject Headings terms and free words, in the CINAHL, MEDLINE, Cochrane, BIOMED, PUBMED, PsycINFO, and EMBASE databases, as described in Chapter 2. Also the IEEE Digital Library was searched. No limitations were applied for the date of publication. Only articles written in English were taken into account. Collected publications went through a selection process involving 3 reviewers. The selection process was based on title, abstract, and complete content, to obtain a final set of publications to be included in the review. In the first step, 2891 publications were found. In the second step, 123 titles were selected as relevant. In the third step, 37 publications were selected, based on their abstracts. In addition, 
30 publications were selected via the free Internet search and from conference proceedings (having no overlap with the publications selected in step 3).

Finally, 41 publications were included in the review, reporting on 17 studies involving 4 robot systems (Paro, NeCoRo, Bandit and Aibo) and 1 undefined robot. Categorizing the publications based on the robot system there were 3 publications on the robot Bandit describing 1 study, 4 publications on the artificial intelligence robot (AIBO) describing 4 studies, 30 publications on the Paro robot describing 8 studies, 2 publications describing 2 studies about the robot NeCoRo, 1 publication with an unspecified robot and 1 publication with an overview of several robots.

Most studies reported positive effects of companion-type robots on (socio)psychological (e.g. mood, loneliness, and social connections and communication) and physiological (e.g. stress reduction) parameters. The methodological quality of the studies was generally low. Although positive effects were reported, the scientific value of the evidence was limited.

\section{High potential user centered robot Interventions for Intramural Psychogeriatric Care}

Literature review revealed that little is known about the effects of socially assistive robots in healthcare. Only for four SAR systems (Paro, Aibo, NeCoRo and Bandit) care related effects were reported and even for these systems results are still limited, as no clinical trials are reported. Also no interventions were reported involving any of the four systems. The study described in Chapter 4 aimed at developing care interventions for the Paro seal robot. Paro was selected for this purpose because, of the four systems mentioned, it is the only system with the European CE mark, guaranteeing basic technical robustness, reliability and intrinsic safety, as described in Chapter 3. Moreover, the large number of publications from the Paro developing team on application and effects supported the potential of Paro. The development of interventions involving Paro should be based on the potential of Paro to add value to existing care provision. For this reason the development was based on the expertise of the staff of four care providing organizations (Sevagram, Proteion, Dignis and Meander). In collaboration with these four organizations, 12 meetings with care staff were organized, three in each organization. Initially two meetings 
were arranged in each organization for the purpose of specifying possible goals, target groups and environments for the application of Paro in intramural psychogeriatric care. In one meeting daily care providing personnel was involved, including nurses, diversional therapists and team leaders. In the other meeting therapists were involved, including psychologists, physical therapists, occupational therapists and medical doctors. The two groups met separately to offer opportunity for all staff to express their opinions without hierarchical confounding. For both meetings at each site an identical procedure was adopted. First an interaction was arranged between a resident and Paro, witnessed by the participating group of staff. Following this, a Metaplan session was held; participants were invited to record their individual views on potential goals, target populations and environments for Paro application. These views were subsequently shared within the group and followed by a group discussion to clarify the collected material. After the results of the first meetings were reported back to the participants, a last meeting was organized in each organization, for which the therapists and medical doctors were invited. The aim of this meeting was to prioritize the identified goals of Paro interventions and to determine the type of outcomes and assessment tools that could assess the added value of each of the interventions. Based on the prioritization, the goals were categorized into three main groups. A Paro intervention was specified within each of these three categories.

1. Application of Paro for therapeutic purposes. This type of intervention aims to provide comfort to individual distressed dementia patients at critical times during the daily routine. Paro can be used to stimulate perception and activate attention, leading to a sense of purpose in activities.

2. Application of Paro to facilitate daily care activities. This type of intervention aims at facilitating the provision of care by professionals. Paro could bring about a desired mindset of the patient, lowering common resistance to activities of daily living (ADL) care tasks executed by the staff. It might function as a diversion or as a means of inducing a more cooperative mood.

3. Application of Paro in support of social visits. This type of intervention aims at supporting social contact between a dementia patient and visiting family members or acquaintances. Paro is then used as an intermediary, facilitating shared attention and conversation. 
The three developed interventions differ in their impact on the provision of care and therefore in the added value they may have. The results of this study and the feasibility study described in Chapter 5 provided the basis for executing the methodology of the effectiveness study.

\section{Effectiveness of Robot Paro in Intramural Psychogeriatric Care: a quasi-experimental study}

We conducted a multi-center quasi-experimental time series ABAB study $(n=91)$ with within-subject comparison. This study, described in Chapter 6, assessed both the short-term effects of the Paro interventions on psychological functioning and psychosocial well-being of patients, and the facilitation of daily care activities by care providers.

The primary outcome was measured on an individual level by a care provider, based on the Individually Prioritized Problems Assessment (IPPA) score. A mood scale was used as secondary outcome, in order to validate that reported effects by the care providers (i.e. IPPA score) would not lead to negative effects by the residents. As a reference, due to the progressive nature of dementia, a Dutch behavioral rating scale for geriatric inpatients was used before and after the interventions period.

In total 71 participants completed the study and 86 individual interventions were conducted; 17 regarding care support and 69 aiming at therapeutic effects. The effect was evaluated with the Wilcoxon signed-rank test. Differentiating to intervention type, the therapeutic related interventions show a significant effect ( $p$-value < $0.001, r=0.42)$, where the care support related interventions do not show a significant effect $(p$-value $=0.58, r=0.03)$.

This study shows that Paro is clearly effective for interventions aiming at a therapeutic effect, if applied in a well thought-out manner and tailored to the individual situation of the elderly. For interventions aiming at care support this study shows no significant effect. 


\section{Methodological considerations}

\section{Development of robot interventions in psychogeriatric care}

Despite all the research and prototype development in the field of robotics, in particular in Socially Assistive Robots, only very few of these robotic systems have actually become available on the market. Maybe not all developments have the potential to actually make it to the market, but there seems to be a general gap between research and development and product delivery to market. This not only contrasts the considerations initiating most of these projects, it also limits the possibilities of conducting real-life trials and developing therapeutic interventions for elderly care. The acceptance of social robots in providing daily care will depend on the added value demonstrated by such systems in practice ${ }^{6}$. Successful implementation of robots and robotic interventions depends highly on the role and contribution of the (end)-users (e.g. healthcare professionals). Without their involvement, embedding social robotics in healthcare has little chance of success. Involving caregivers from multiple disciplines from the very beginning led to a broad and diverse range of potential goals. The participating caregivers were enthusiastic and, given the collective goals, saw considerable potential in the application of the robot interventions. The advantage of this approach is also a reduction of resistance to the application of a robotic "toy" in healthcare 7 . The formulation of the three Paro interventions intended not only to structure the application of Paro in daily care provision, they also intended to define how Paro was evaluated in Dutch care provision during an effectiveness study.

We included, from the start of the intervention development, a broad group of health care providers, leading not only to meaningful care interventions, but also to substantive involvement of the care providers in the use of robots in daily care practice. This also contributed to a reduced resistance to the use of robots in healthcare, both from care providers and the family members of the patients. By splitting up the focus groups (daily care providers versus medical staff) hierarchical confounding, in medical practice not uncommon ${ }^{8}$, was limited. The feasibility study resulted in manageable applicable measurement instruments. 


\section{Measurements of effectiveness of robot interventions in intramural elderly care}

The reported literature review identified only a very limited set of studies for which a wide search was required. The studies that were found were mainly reported in conference proceedings, underlining the initial stage of the application of this type of robot system. Most research is done in Japan, with a limited set of robots (mostly Paro and AIBO), and not yet clearly embedded in a care need-driven intervention. Although obvious positive effects are reported, the scientific quality of the evidence is limited owing to methodological limitations (e.g. small sample sets, short durations, no control group, no randomization). The studies found were mainly of an exploratory nature. In general, relations between the type of outcomes aimed for, either related to support of care or support of independence, and the application of the robot system in care, are not well established. Within any health care system, care interventions are adopted because of their added value. The reported outcomes were only partly directly linked to desired outcomes, and related to the desired added value. The expected added value must be clarified along with their qualitative and quantitative indicators and outcome measure. We conducted a multi-center quasi-experimental time series $A B A B$ study with within-subject comparison. This study assessed both the short-term effects of the Paro interventions on psychological functioning and psychosocial well-being of patients, and the facilitation of daily care activities by care providers.

The primary outcome was measured on an individual level by a care provider, based on the Individually Prioritized Problems Assessment (IPPA) score. A mood scale was used as secondary outcome, in order to validate that reported effects by the care providers (i.e. IPPA score) would not lead to negative effects in the residents. As a reference, due to the progressive nature of dementia, a Dutch behavioral rating scale for geriatric inpatients was used before and after the interventions period. Because of the highly individual character of the interventions a comparison against a control group provided with a placebo or "therapy as usual" was discarded. The use of a placebo tool only gives insight into the differences between the intervention group and the specific placebo group; generalizing these differences has no grounding ${ }^{9}$. Since no other large scale multi-centered study is published 
involving the use of Paro based on individually defined interventions, these results stand on their own and cannot be compared with similar studies.

The therapeutic related interventions are clearly effective, however for the care support related interventions no convincing positive results are reported. These results show that initially the use of Paro led to a more negative effect than in the period without Paro (i.e. the first phase B scores lower than the first phase A, for care support interventions). The results also show that in the subsequent $A B$ phase, the effects are positive (i.e. the second phase $B$ scored higher than the second phase $A$, wherein the second phase $A$ is almost equal to the first phase A). Evaluating interviews with care providers revealed that they initially had difficulty combining Paro with the provision of care (e.g. washing or dressing). After they had gained more experience in the use of Paro, they were better able to combine Paro with the provision of care. This could be an explanation for the differences between the first and the second $A B$ phase. In certain situations, the experience of care givers with Paro is of major impact on the effect of interventions. For a successful embedding of Paro in daily care practice therefore, adequate attention should be paid to training of care providers in the use of the robot.

In order to get insight into the effects for subgroups (e.g. male and female), a subgroup analysis should be performed. Although no significant difference was observed between male and female participants and also no significant difference was observed in terms of effects compared to the dementia phase of the participants, these observations can only be seen as indications of possible effects. Due to the limited number of participants in this study for each subgroup (i.e. a small power) no conclusive results can be presented for these subgroups.

\section{Theoretical considerations}

\section{Robot technology in care support for people with dementia}

Robots can contribute to care in terms of their capacity (number of care providers), quality (performing tasks very accurately and specifically), financial ramifications (robots support or even assumed tasks of trained personal), and independence 
(e.g. increase feeling of autonomy and self-management). These categories partially overlap, but each has its own inherent value. An unlimited amount of money would not solve the capacity problem: there are just not enough caregivers available. On the other hand, a multitude of care providers and money do not necessarily improve the quality of care or increase the positive experiences. SAR can play a role in assisting people similar to the role guide dogs have for visually impaired people. They can be a buddy providing companionship, a sense of safety and support for social activity.

\section{Focusing on robot enabled therapeutic and care support in intramural elderly care}

Our study clearly shows that the developed therapeutic interventions are successful. The success is not only attributed to the robot, the role of the caregiver is not to be underestimated. The robot must be seen as an adjunct support for caregivers in providing quality care, focused on the individual client. The role of the robot is, however a crucial factor. The interventions are, in most cases, based on situations where regular interventions proved inadequate. The specific features of the robot that are essential for the reported effects, are still insufficiently known ${ }^{10}$. Research into Animal Assistive Therapy (AAT) shows that animals can have a positive effect on people with dementia ${ }^{11}$. Live animals used in daily care practice also implicate practical issues. Robots based on animals are targeted on the positive effects of AAT, but without the associated practical difficulties. Paro has properties, we know from personal interviews with the creator of Paro, Dr. Shibata, that are well thought out and are specifically aimed at psycho-geriatric patients. Previous research with a similar robot, i.e. NeCoRo, a robot cat, shows much less positive effects. The probable reason for this is that the cat $\mathrm{NeCoRo}$ does have the appearance of a cat but its behavior does not relate to a normal cat. From a cat it is expected that it walks, runs and even climbs in the curtains, in other words, is physically active. However, $\mathrm{NeCoRo}$ did not have these moving properties. Because the appearance of the cat did not match the physical behavior, the robot did not meet the expectations. It did look like a cat, but did not behave like that. A second alleged reason was that some people may have an aversion to cats. This was the reason that Dr. Shibata wanted to develop a robot better suited to the expectations and that people were likely to 
have no aversion against. This led to the idea of a baby seal robot. Paro, in addition, has the size and the weight of a human baby. The expectation was that this would evoke basic memories of its users.

\section{Future directions}

In socially assistive robotics the technical demands are not the critical artefacts, but the acceptance of the robot as added value in care practice is. An essential step in this process is sound assessment of outcomes of care robotics in daily care provision. Without such assessment reimbursement will become a problem, undermining the application and further development of socially assistive robotics. Follow-up research is needed, to validate the primary results of this study (i.e. a positive effect of the therapeutic interventions) for various subgroups and to get more insight in the possible effects of care support interventions.

The acceptance of social robots in providing daily care will depend on the added value demonstrated by such systems in practice. Successful implementation of robots and robotic interventions depends highly on the role and contribution of the (end)-users (e.g. healthcare professionals). Without their involvement, embedding social robotics in healthcare has little chance of success. Too often though, systems are developed without the full involvement, from start to finish, of the intended users. While understandable -there are still major technical challenges involved in SAR- this is a missed opportunity. Finally, information and/or instructions for both care receivers and care providers must be available. All in all, the intervention must also convince (public) care financers to reimburse the application of robot interventions within the healthcare system.

Partly prompted by the expectations that people have of robots, it is of interest to developers that they create robots that are specifically focused on certain tasks or supports, in line with the care questions of the intended users. Technology developers are making too often inclined systems with many capabilities and many configuration options. The technical challenges prevail with losing sight of the simplicity and purposefulness of the system as a consequence. 
Robotics is increasingly finding its way into everyday care practice. Partly motivated from a cost aspect or capacity problems, but also motivated by the need for more self-control and quality of life. Older people are still (too) often seen as just customers of this technology (due to their increasing dependence), while older people also can be seen as pioneers and early adopters. Older people are an interesting population to explore innovations in healthcare technology. They should not be treated as a 'burden' but rather as partners in the development of technology-driven care innovations. This provides not only a huge population of interested end-users (not from a gadget point of view, but from a quality of life perspective), but also sets the position of the elderly in relation to new technology in a different perspective, as an innovative generation.

\section{References}

1. Bemelmans R, Gelderblom G), Jonker P, de Witte L. Socially Assistive Robots in Elderly Care: A Systematic Review into Effects and Effectiveness. Journal of the American Medical Directors Association. 2012;13(2):114-120.e111.

2. Bemelmans R, Gelderblom G), Jonker P, de Witte L. State of the Art in Socially Assistive Robots for Elderly Care. submitted. 2012.

3. Bemelmans R, Gelderblom G), Spierts N, Jonker P, de Witte L. Development of robot interventions for intramural psychogeriatric care. GeroPsych: The Journal of Gerontopsychology and Geriatric Psychiatry. 2013;26(2):113-120.

4. Bemelmans R, Gelderblom GJ, Jonker P, de Witte L. How to use Robot Interventions in intramural Psychogeriatric Care; A Feasibility Study. Applied Nursing Research. 2015.

5. Bemelmans R, Gelderblom GJ, Jonker P, de Witte L. Effectiveness of Robot Paro in Intramural Psychogeriatric Care: A Multicenter Quasi-Experimental Study. Journal of the American Medical Directors Association. 2015.

6. Beer JB PA, Mitzner TL, Rogers W. Understanding robot acceptance. Technical report Atlanta, GA. Georgia Institute of Technology. 2011.

7. Broadbent E, Stafford R, MacDonald B. Acceptance of Healthcare Robots for the Older Population: Review and Future Directions. Int J of Soc Robotics. 2009;1 (4):319-330.

8. Currie G, Lockett A, Finn R, Martin G, Waring J. Institutional Work to Maintain Professional Power: Recreating the Model of Medical Professionalism. Organization Studies. 2012;33(7):937-962. 
9. Byng R, Norman I, Redfern S. Using Realistic Evaluation to Evaluate a Practice-level Intervention to Improve Primary Healthcare for Patients with Long-term Mental Illness. Evaluation. 2005;11 (1):69-93.

10. Heerink M, Albo-Canals J, Valenti-Soler M, et al. Exploring Requirements and Alternative Pet Robots for Robot Assisted Therapy with Older Adults with Dementia. In: Herrmann G, Pearson M, Lenz A, Bremner P, Spiers A, Leonards U, eds. Social Robotics. Springer International Publishing; 2013(8239):104-115.

11. Banks MR, Willoughby LM, Banks WA. Animal-assisted therapy and loneliness in nursing homes: use of robotic versus living dogs. Journal of the American Medical Directors Association. 2008(3):173-177. 
Valorisation 


\section{Valorisation}

This thesis describes the results of the research on the possibilities and effect of socially assistive robots in the intramural elderly care. The results are promising, as they show the potential robot based interventions can have in increasing the quality of care. These results can only be of benefit to our care system, including but not limited to care professionals, care financers, care takers and public health services, if the results are translated to applicable and practical applications in daily care practice.

\section{Relevance}

Accessibility, quality and financial durability of health care and elderly care have been placed, by initiative of the European summit in Nice, on the European agenda. By the increasing demographic ageing the number of people with health problems strongly increases. The need for autonomy and the limited availability of care providers make the quest for technological support relevant. Moreover, the possible increase of care quality plays a role. A robot is able to process data in a very fast and objective manner, does not become sick or tired, has no stress and carries out its tasks with a high degree of exactitude. By the increasing technological developments the cost of this technology decrease and people become more and more familiar with technological appliances. Cost reduction in care surroundings can be realized because robots can take over trained staff tasks. Moreover, patients are less dependent on (human) care providers, which can reinforce the feeling of self-control and autonomy.

\section{Target groups}

\section{Elderly}

The research described in this thesis focuses on elderly people in the intramural psychogeriatric care. People who participated in the field studies, as described in Chapters 5 and 6, were selected based on therapeutic or care support objectives. Of the three developed interventions, as described in Chapter 4 , the intervention aiming at supporting social visits was not included in the effectiveness study described in Chapter 6 . This intervention could however be of significant importance 


\section{CHAPTER 8}

to family members and informal care givers, supporting the meaningful context of social visits. It is therefore recommendable to investigate the effectiveness of these interventions. Although the target group in this thesis was limited to elderly people in intramural psychogeriatric care, there are no obvious objections to translate the results to elderly people receiving psychogeriatric care living at home.

Another possible target group is people with intellectual disabilities, both elderly people and children. A pilot study involving this target group has already been performed, the results are only indicative but promising enough to be further investigated.

\section{Care professionals}

The developed interventions described in Chapter 4 were co-created with 31 professional care givers, including psychologists, physical therapists, occupational therapists, medical doctors, nurses, diversional therapists, and team leaders. The pilot study described in Chapter 5, investigating the feasibility of the interventions, was carried out by 16 care professionals in three different care institutions. The effectiveness study, described in Chapter 6, was performed by 28 care professionals from six different care locations. These care professionals applied the interventions in daily care practice, in doing so not only contributing to the research but also gaining experience in applying robot based interventions in daily care. The developed training course, mentioned in Chapters 4, 5 and 6, can also be used to further support implementation of Paro interventions in care practice.

\section{Researchers}

More research is needed to further investigate the potential of socially assistive robots in care. It is not sufficient to examine the effect the robots will have in a laboratory setting or in a conditioned field study. This research focused on psychogeriatric care, but socially assistive robots can be of benefit to other user groups and domains. The procedure used in this project, from intervention development to effectiveness study, can provide guidance to further research involving socially assistive robots. Our approach lead to user-centered interventions, co-created with care professionals. Resulting in practically applicable and meaningful robot interventions. The integral involvement of health professionals and healthcare organi- 
zations, both in the design of interventions and the effectiveness study, lead to a greater commitment and acceptance with regard to the use of robots in healthcare.

\section{Care financers}

The results presented in Chapter 6 provide the basis for care financers to reimburse the application of Paro involved interventions. Without such reimbursement the broad use and implementation of meaningful robot based interventions will be unnecessarily slowed down.

\section{Industry}

Broad implementation of robot based interventions also requires thorough maintenance and service contracts. The robot must have such a degree of effectiveness, both functionally and in use, that the patients and care providers are willing to use the robot in daily living. Health service providing companies should guarantee a high level of availability and reliability of the robot systems. They could also provide the necessary training of care professionals in order to successfully implement robot interventions in daily care. The service level agreements should target multi levels: providing service to individual users, service-based agreements targeting all users and corporate level agreements.

\section{Innovation and further activities}

Products developed in this research project were the three interventions, the blended training course and the (individualised) measurements instruments used in the feasibility and effectiveness study. The seal robot Paro was already available and no adjustments were needed (or possible).

In addition to these products and the effectiveness of Paro interventions, perhaps the greatest value of this research is that robot based interventions can be seen as tools that can make a substantial contribution to improving the quality of care. $A$ variety of initiatives is undertaken by the participating healthcare organizations to stimulate further implementation of these interventions and to consider other useful applications. 


\section{Summary}

Given the ongoing development of robotics and the increasing demand for care assistance, both from a quantitative as from a qualitative perspective, in light of an aging society, the potential robots can have in increasing the quality of care is relevant and necessary. The main objective of this study was to develop and evaluate care interventions using socially assistive robots, focusing on intramural psychogeriatric care.

First a systematic literature review was conducted to assess the published effects and effectiveness of robot interventions aiming at social assistance in elderly care. We searched, using Medical Subject Headings terms and free words, in the $\mathrm{Cl}$ NAHL, MEDLINE, Cochrane, BIOMED, PUBMED, PsycINFO, and EMBASE databases. Also the IEEE Digital Library was searched. No limitations were applied for the date of publication. Only articles written in English were taken into account. Collected publications went through a selection process. In the first step, publications were collected from major databases using a search query. In the second step, 3 reviewers independently selected publications based on their title, using predefined selection criteria. In the third step, publications were judged based on their abstracts by the same reviewers, using the same selection criteria. In the fourth step, one reviewer made the final selection of publications based on complete content. Finally, 41 publications were included in the review, describing 17 studies involving 4 robot systems. Most studies reported positive effects of companion-type robots on (socio)psychological (e.g., mood, loneliness, and social connections and communication) and physiological (e.g., stress reduction) parameters. The methodological quality of the studies was, mostly, low. Although positive effects were reported, the scientific value of the evidence was limited.

Following the systematic literature review we performed a desk research into the state of the art in Socially Assistive Robots (SAR) for application in long term elderly care. A desk research in both the formal and grey literature was conducted. A web based search for SAR systems in databases (CORDIS, IEEE), journals and proceedings of, HRI, RIA, ICORR, ICRA, ROMAN, IEEE and IFRR conferences was carried out. Further a free Google and Google scholar based search was executed. A collection of systems was built in 4 steps. In the first step all interactive robot systems were brought together. In the following steps socially assistive robots were selected 
based on their suitability for application in (long term) elderly care. Finally a set of 25 socially assistive robots potentially suitable for elderly care was selected. Despite the vast amount of research and prototype development in this field only a limited number of socially assistive robots are actually available to be put to use within elderly care. The seal robot Paro seemed to be the most promising robot available.

The actual application of social robots in the provision of daily care depends on demonstrated added value of such systems. The availability of a technical system as such is insufficient for achieving added value. Rather, care interventions need to be defined in terms of the goal, target group, environment, and how care staff should act to pursue effective application of a robot system. For the seal robot Paro three such interventions have been developed in collaboration with psychogeriatric care professionals. These interventions also outline the application of Paro in care for the subsequent effectiveness study.

The interventions were categorized into three main groups:

1. Application of Paro for therapeutic purposes. Depending on individual needs Paro can stimulate perception, psychological functioning, psychosocial well-being, and social behavior. For patients at risk, Paro can reactivate the person at the individual level.

2. Application of Paro to facilitate daily care activities, making use of the attention focused on Paro or its comforting ability. For care providers the presence of Paro during daily care activities could enhance patients' well-being and thus facilitate the required care activities. For some patients these daily activities can cause anxiety or stress and make the task of the caregiver more difficult.

3. Application of Paro in support of social visits. Because of progressing dementia, the attractiveness of family visits to dementia patients is difficult to maintain. The activating qualities of Paro on the patient could be used to provide a shared focus point for the patient and the patient's family member(s) and thus raise the attractiveness of such visits.

Before performing a large scale effectiveness study we first investigated how the interventions could best be implemented in daily care practice, and what the experiences of care staff, informal caregivers and patients were when doing so. In addition we wanted to evaluate the experienced added value of these interventions. 
Paro was used according to individualised interventions, aiming at predefined specific care problems, during a three week period. Selected residents, from Small scale care units (8-10 residents each) in three Dutch care institutions for intramural psychogeriatric care, were offered Paro ones or twice a week. A total of 23 dementia patients, 22 female and 1 male, participated. All three intervention types were applied, one for therapeutic purposes, one for facilitating daily care activities and one to support social visits. The experiences of care staff, informal caregivers and patients with Paro were registered qualitatively by means of a registration form in which each occasion of Paro use was briefly reported. Additionally, care staff was interviewed using a semi-structured qualitative questionnaire. The 23 residents were involved in 36 individually defined interventions, and in total 71 sessions were carried out. In the majority of cases, care staff and patients considered the Paro interventions to be of added value for the care provided. The pilot showed that the use of Paro can be well individualised to the needs of patients, the resulting individual Paro intervention can be well implemented in day to day care and Paro may have added value when used in a well-directed way.

Finally the outcomes of the developed Paro interventions, applying the robot in psychogeriatric care, were evaluated. A multicenter quasi-experimental time series ABAB study $(n=91)$ with within-subject comparison was conducted to assess both the short-term effects of the Paro interventions. Spread over 6 different locations in 3 Dutch care institutions for intramural psychogeriatric care, a total of 91 patients with dementia in all stages of dementia participated. Two user-centered intervention types were applied, one for therapeutic purposes and one for the facilitation of daily care activities. Effectiveness was measured with a goal attainment scale (IPPA) and a mood scale (Coop/Wonca), by means of a registration form. A total of 106 user-specific interventions were defined for 91 participants; 71 participants completed the study, 14 were men and 57 were women. The therapeutic interventions show a significant effect $(p<.001)$, for the care support interventions however a significant effect was not shown.

Paro should be seen as a tool for care staff and not as a replacement of care. Successful implementation of Paro in daily intramural psychogeriatric care practice can increase the quality of care and the quality of life for the elderly. 


\section{Samenvatting}

De voortdurende ontwikkeling van robots en de toenemende vraag naar zorgondersteuning, zowel vanuit een kwantitatief als een kwalitatief perspectief, in het licht van een vergrijzende samenleving, maken de vraag naar de bijdrage die robots kunnen hebben in het verhogen van de kwaliteit van zorg niet alleen relevant maar ook noodzakelijk. Het hoofddoel van deze studie was het ontwikkelen en evalueren van zorginterventies, gebaseerd op sociaal ondersteunende robots, voor de intramurale psychogeriatrische zorg.

Eerst is een systematische literatuurstudie uitgevoerd, om de gepubliceerde effecten en de effectiviteit van robotinterventies gericht op sociale ondersteuning in de ouderenzorg in kaart te brengen. Diverse databases zijn daarbij geraadpleegd, waaronder CINAHL, MEDLINE, Cochrane, BIOMED, PUBMED, PsycINFO, EMBASE en de IEEE Digital Library. Alleen Engelstalige artikelen, ongeacht publicatiedatum, zijn daarbij geraadpleegd. De verzamelde publicaties zijn middels een selectieproces gefilterd. In de eerste selectiestap zijn publicaties verzameld uit de grote databases, met behulp van een zoekopdracht. In de tweede stap zijn de publicaties door 3 beoordelaars onafhankelijk van elkaar beoordeeld op basis van de titel, met vooraf gedefinieerde selectiecriteria. In de derde stap zijn de overgebleven publicaties beoordeeld op basis van een samenvatting, wederom onafhankelijk door dezelfde 3 beoordelaars, waarbij dezelfde selectiecriteria zijn gehanteerd. In de vierde stap is de definitieve verzameling van publicaties samengesteld, door 1 beoordelaar op basis van de volledige inhoud van de publicaties. Uiteindelijk zijn 41 publicaties opgenomen in de review, waarin 17 studies zijn beschreven met 4 verschillende robotsystemen. De meeste studies rapporteerden positieve effecten van gezelschapsrobots op (sociaal-)psychologisch (o.a. stemming, eenzaamheid en sociale verbanden en communicatie) en fysiologisch (o.a. stressreductie) vlak. De methodologische kwaliteit van de onderzoeken was meestal laag. Hoewel positieve effecten werden gerapporteerd, leek de wetenschappelijke waarde van het bewijsmateriaal beperkt.

Volgend op de systematische literatuurstudie is een deskresearch uitgevoerd naar de state-of-the-art ten aanzien van Sociaal Assisterende Robots (SAR) in de langdurende ouderenzorg, in zowel de formele als de grijze literatuur. Een webbased zoek- 
tocht naar SAR-systemen in databases (Cordis, IEEE), tijdschriften en conference proceedings van HRI, RIA, Icorr, ICRA, ROMAN, IEEE en IFRR is uitgevoerd, verder aangevuld met informatie verzameld via Google en Google-scholar. De verzamelde robotsystemen zijn middels een selectieproces, bestaande uit 4 stappen, gefilterd. In de eerste stap zijn alle robotsystemen verzameld die primair gericht zijn op interactie. In de volgende stappen is de verzameling systemen uitgedund tot een verzameling sociaal assisterende robots geschikt voor de (langdurende) ouderenzorg. Uiteindelijk zijn 25 robotsystemen geselecteerd die potentieel geschikt zijn om gebruikt te worden in de (langdurende) ouderenzorg. Ondanks de enorme hoeveelheid onderzoek en prototypeontwikkeling op dit gebied, is slechts een beperkt aantal sociaal ondersteunende robots daadwerkelijk beschikbaar om te worden ingezet binnen de ouderenzorg. De zeehondrobot Paro leek de meest veelbelovende beschikbare robot.

De daadwerkelijke toepassing van sociaal ondersteunende robots in de context van de dagelijkse zorgpraktijk is, uiteraard, sterk afhankelijk van hun aantoonbare praktische meerwaarde. De beschikbaarheid van een technisch systeem als zodanig, is onvoldoende om een eventuele meerwaarde aannemelijk te maken. Zorginterventies moeten gedefinieerd worden, waarbij de zorgvraag, het doel, de doelgroep, de omgeving en de rol van het verzorgend personeel eenduidig beschreven is, teneinde een zinvolle toepassing van robots in de zorgpraktijk te bewerkstelligen.

Voor de zeehondrobot Paro zijn drie zorginterventies ontwikkeld in nauwe samenwerking met zorgprofessionals uit de intramurale psychogeriatrische zorgpraktijk.

De drie interventies werden ingedeeld in drie categorieën:

1. Toepassing van Paro voor therapeutische doeleinden. Afhankelijk van de individuele behoeften kan Paro perceptie, psychisch functioneren, psychosociaal welzijn en sociaal gedrag stimuleren. Voor patiënten met een (te) laag bewegingsritme kan Paro activatie stimuleren op individueel niveau.

2. Toepassing van Paro in de ondersteuning van dagelijkse zorghandelingen, gebruikmakend van de aandacht die Paro vraagt (afleiding) en zijn vermogen om mensen gerust te stellen. Voor de zorgverleners kan de aanwezigheid van Paro bij de dagelijkse zorghandelingen het welbevinden van patiënten verbeteren en daarmee de benodigde zorg vergemakkelijken. Voor sommige patiënten kunnen 
deze dagelijkse zorghandelingen gevoelens van angst of stress veroorzaken en zo de zorgtaak van de verzorger bemoeilijken.

3. Toepassing van Paro ter ondersteuning bij familiebezoek. Het progressieve karakter van dementie blijkt in sommige gevallen een complicerende factor te zijn voor familieleden om een waardevolle invulling te geven aan de familiebezoeken. De aantrekkelijkheid van de bezoeken komt daardoor soms onder druk te staan. De activerende eigenschappen van Paro op de patiënt kunnen gebruikt worden om gedeelde aandacht voor de patiënt en de familie te realiseren, Paro fungeert dan als een soort intermediair tussen familie en bewoner, om zo de aantrekkelijkheid van de bezoeken te verhogen.

Deze zorginterventies gaven ook richting aan de toepassing van Paro in de intramurale ouderenzorg in de uiteindelijk uitgevoerde effectiviteitsstudie. Voordat het grootschalige effectiviteitsonderzoek werd uitgevoerd is eerst onderzocht hoe de interventies het beste in de dagelijkse zorgpraktijk uitgevoerd konden worden, en wat de ervaringen van het verzorgend personeel, de mantelzorgers en de patiënten daarbij waren. Daarnaast wilden we de ervaren toegevoegde waarde van de interventies evalueren.

Paro werd gebruikt volgens geïndividualiseerde interventies gericht op vooraf bepaalde specifieke problemen, gedurende drie weken. Geselecteerde bewoners van kleinschalige zorgunits (8-10 bewoners elk) in drie Nederlandse zorginstellingen voor intramurale psychogeriatrische zorg, kregen 1 à 2 keer per week Paro aangeboden. In totaal hebben 23 bewoners, 22 vrouwen en 1 man, deelgenomen. Uit alle drie de categorieën zijn interventies toegepast. De ervaringen van het verzorgend personeel, de familieleden en de bewoners werden kwalitatief geregistreerd middels een registratieformulier waarin per interventie de inzet van Paro kort werd gerapporteerd. Daarnaast werd het verzorgend personeel geïnterviewd met behulp van een semigestructureerde kwalitatieve vragenlijst. Voor de 23 bewoners zijn 36 individuele zorginterventies gedefinieerd en in totaal zijn 71 sessies uitgevoerd. In de meeste gevallen werden de Paro-interventies door het verzorgend personeel van toegevoegde waarde geacht. De pilot toonde aan dat de Paro-interventies afgestemd kunnen worden op individuele zorgvragen van de bewoners. De geïndividualiseerde zorginterventies konden goed ingebed worden in de dagelijkse zorgpraktijk en toonden voldoende potentieel te hebben bij gerichte inzet. 
Ten slotte zijn de ontwikkelde interventies in de zorgpraktijk toegepast, teneinde in een grootschalige effectiviteitsstudie de effecten te evalueren. Een multicenter quasi-experimenteel time series $A B A B$ onderzoek $(n=91)$ met within-subject vergelijking is uitgevoerd, om de kortetermijneffecten van de Paro-interventies te meten. Verdeeld over 6 verschillende locaties in 3 Nederlandse zorginstellingen voor intramurale psychogeriatrische zorg, hebben in totaal 91 patiënten, met dementie in alle stadia, deelgenomen. Twee user-centered interventietypen zijn toegepast, een gericht op therapeutische doelen en een gericht op het faciliteren van dagelijkse zorghandelingen. Effectiviteit werd gemeten met een aangepaste goal attainment scale (IPPA) en een mood-scale (Coop / Wonca). In totaal zijn 106 specifieke interventies gedefinieerd voor 91 deelnemers; 71 deelnemers hebben het onderzoek voltooid, waarvan 14 mannen en 57 vrouwen. Een significant effect $(p<0,001)$ werd gemeten voor de therapeutische interventies, voor de zorgondersteunende interventies daarentegen werd geen significant effect gemeten.

Paro moet worden gezien als een instrument voor het verplegend personeel en niet als vervanging van de zorg. Succesvolle implementatie van Paro in het dagelijks intramurale psychogeriatrische zorgpraktijk kan de kwaliteit van de zorg en de kwaliteit van leven van de bewoners verhogen. 


\section{Dankwoord}

Het duurt even, maar dan heb je ook wat! Het proefschrift is klaar. Een bordje dat ik lang geleden aan de muur van een promovendus bij de Universiteit Maastricht heb zien hangen is veelzeggend: promoveren is voor $90 \%$ transpiratie en voor $10 \%$ inspiratie. Zonder de hulp, begeleiding, acceptatie, correctie, motivatie en inspiratie van velen was dit nooit gelukt. Allen die een bijdrage, in welke vorm, hoedanigheid of omvang dan ook, hebben geleverd, wil ik bij dezen van harte bedanken. Met een aan zekerheid grenzende waarschijnlijkheid ga ik een aantal personen of organisaties tekort doen, toch wil ik graag een aantal mensen expliciet bedanken.

Allereerst, uiteraard, mijn gezin. Zonder hun steun, begrip en motivatie was dit een kansloze missie geweest. Daisy, Gyan en Livy, jullie hebben mij altijd gesteund, gestimuleerd en de ruimte gegeven dit (maar eigenlijk alles waar ik aan ben begonnen, of nog mee bezig ben) te doen en af te ronden. Ik zeg het te weinig, en woorden zijn ontoereikend, maar zonder jullie kan, ben en wil ik niet(s).

Luc, jij hebt mij een jaar of 6 geleden gevraagd of ik interesse had in een promotietraject. Lang heb ik daar niet over hoeven nadenken. Zeker omdat het onderwerp, techniek in de zorg, mij erg aansprak. Jij hebt mij vanaf het begin altijd gemotiveerd en de ruimte gegeven, aangespoord, (bij)gestuurd en gecorrigeerd wanneer nodig, geïnspireerd met visie en ideeën en geholpen met schrijven. De grote lijn werd door jou geborgd, de wetenschappelijke kwaliteit was leidend. Maar wat me vooral is bijgebleven is jouw niet aflatende vertrouwen (en ik heb toch echt mijn best gedaan daaraan te knabbelen) in een goede afloop, je hebt mij nooit het gevoel gegeven dat dit niet ging lukken. Mijn waardering en dank daarvoor is groot.

Pieter, jij was mijn andere promotor, verder weg qua fysieke afstand maar daardoor niet minder betrokken. Altijd bereid om mee te denken, mee te schrijven, te corrigeren en te discussiëren over de te volgen stappen. De inhoudelijke terugkoppeling was altijd snel en uitgebreid, dat zegt veel over de betrokkenheid. Ook als wij met andere robotprojecten bezig waren (of wilden beginnen) was jij altijd bereid mee te denken, ons te ontvangen in Delft en van materialen te voorzien. Een betere combinatie dan jou en Luc is, op het gebied van zorg en technologie, nauwelijks denkbaar. Bedankt voor alle ondersteuning en begeleiding. 
Ook de andere collega's van de kenniskring Technologie in de Zorg, bedankt voor alle steun, ondersteuning en inhoudelijke bijdragen. Bea, als managementassistente van Luc onze steun en toeverlaat. Als er iets georganiseerd moest worden had jij het, nog voordat het gevraagd was, al geregeld. Uta, bedankt voor alle adviezen, voor de tijd die je vrijmaakte om te luisteren en voor de inhoudelijke feedback. Nadine, met name bij de ontwikkeling van de interventies heb jij een grote bijdrage geleverd. Frans en René, bedankt voor het opzetten van de blended learning cursus, die cursus heeft er mede voor gezorgd dat het praktijkonderzoek goed van start kon gaan. Tanja en Ezra, dankzij jullie inbreng is de pilot goed verlopen. Claudia, met jouw afstudeeropdracht heb je mij erg geholpen bij het uitvoeren van de effectenstudie. Alle dames van het robotica-team, Claire, Reneé, Loek, Sandra en Rianne, bedankt voor alle feedback en ondersteuning.

Ook voor de collegae van de faculteit ICT, bedankt voor het begrip (zeker Ron en Marcel), de interesse en de hulp. Marcel, jij had altijd een luisterend oor en inspirerend praatje. Peter, en ook jouw voorganger Bert, dank voor de ruimte die jullie mij gegeven hebben dit te kunnen doen. Jan, bedankt voor alle tijd die jij gestoken hebt in het reviewen en verbeteren van de artikelen en hoofdstukken, en voor het meedenken en discussiëren over de te volgen stappen. Rom, met Jef een van mijn leermeesters, jij was ook een van de eersten die mij motiveerde dit te gaan doen, bedankt daarvoor.

En dan Gert Jan. Jij bent ons ontvallen, ontnomen. Een onbeschrijfelijk groot verlies, voor iedereen die jou kende. Jij was mijn copromotor, mijn dagelijkse begeleider. Wij hebben jaren samengewerkt, ik had het geluk en genoegen onder jouw begeleiding te mogen en kunnen werken. Jij was bijzonder prettig in de omgang, een goed mens, sociaal bevlogen, erg betrokken (bij al jouw medewerkers), inhoudelijk op het gebied van technologie in de zorg (en zeker robots in de zorg) een echte visionair die ook heel goed wist hoe het in de dagelijkse zorgpraktijk ingebed moest worden. Woorden schieten tekort, maar zonder jou zou ik nooit tot hier gekomen zijn. Ik zal je nooit vergeten, bedankt voor alles, voor wat je deed maar vooral voor wie je was. 
Tot slot wil ik de zorginstellingen Sevagram, Proteion, Orbis, Meander en Lentis en alle betrokken medewerkers, zorgverleners, familieleden, teamleiders en uiteraard alle bewoners die hebben deelgenomen van harte bedanken voor jullie bijdrage, inspiratie en motivatie. Een speciaal woord van dank aan Miriam Jacobs, Astrid Mulken-Kurvers en Lies Coenen voor hun enthousiasme en medewerking. De tijd, ruimte en energie die jullie allemaal hebben besteed en gegeven gedurende dit hele traject was een enorme inspiratie. Ik hoop dat al die inspanning de moeite waard was en dat dit resultaat een steentje bijdraagt aan de kwaliteit van zorg die jullie leveren en ervaren. 


\section{About the author}

Roger Bemelmans was born in Nuth, the Netherlands (1972). After completing his ElectricalEngineering education (at MTS Heerlen, a middle-level applied educational program) in 1993, he studied Computer Science at Heerlen Polytechnic (HTS Heerlen) for which he received his bachelor degree in 1997. From September 1997 till August 1998 he worked at ABP in Heerlen as software engineer. In September 1998 he started working at Zuyd University as a teacher in computer science. In 2000 he started his study at Maastricht University, for which he received his bachelor of science degree in Knowledge Engineering in 2006, and his master of science degree in Operations Research in 2009.

With a multidisciplinary background in electrical engineering, computer science, knowledge engineering, operations research, assistive technology in health care, and teaching, he has working experience as a PhD student at the Research Centre for Technology in Care at Zuyd University. He has been working at the faculty of ICT at Zuyd University from 1998, currently primarily concerned with curriculum and research development.

His main interests are the innovation, development and integration of intelligent systems supporting health care and overall well-being. 


\section{List of publications}

\section{International journals}

Bemelmans R, Gelderblom G), Jonker P, de Witte L. Socially assistive robots in elderly care: A systematic review into effects and effectiveness. Journal of the American Medical Directors Association 2012;13:114-120. DOI: 10.1016/j. jamda.2010.10.002.

Bemelmans R, Gelderblom G), Spierts N, Jonker P, de Witte L. Development of robot interventions for intramural psychogeriatric care. GeroPsych: The Journal of Gerontopsychology and Geriatric Psychiatry 2013;26(2):113-120. DOI 10.1024/1662$9647 /$ a000087.

Bemelmans R, Gelderblom GJ, Jonker P, de Witte L. How to use robot interventions in intramural psychogeriatric care; A feasibility study. Applied Nursing Research 2015. DOI: 10.1016/j.apnr.2015.07.003.

Bemelmans R, Gelderblom G), Jonker P, de Witte L. Effectiveness of robot Paro in intramural psychogeriatric care: A multicenter quasi-experimental study. Journal of the American Medical Directors Association 2015. DOI: 10.1016/j. jamda.2015.05.007.

\section{National publications}

Cremers G, Bemelmans R, Gelderblom G). Rolstoelsimulator: selecteren van de beste rolstoelbediening. Nederlands Tijdschrift voor Revalidatiegeneeskunde 2011;1:21-22.

Gelderblom G), Bemelmans R, de Witte L. Sociale robots in de zorg. FMT gezondheidszorg 2011;10:56-58.

Loerts M, Soler MV, Heerink M, Bemelmans R. Knuffelen met nieuwe vrienden, een handreiking voor zorgprofessionals bij de inzet van robotdieren in de zorg voor mensen met dementie. ISBN 978-90-77901-64-9, 2014. 


\section{Conference proceedings and abstracts}

Bemelmans R, Gelderblom GJ, Jonker P, de Witte L. The potential of socially assistive robotics in care for elderly: A systematic literature review. Gerontechnology 2010;9(2):195.

Gelderblom GJ, Bemelmans R, Spierts N, Jonker P, de Witte L. Development of PARO Interventions for Dementia Patients in Dutch Psychogeriatric Care. Social Robotics 2010;6414:253-258.

Bemelmans R, Gelderblom GJ, Jonker P, de Witte L. The Potential of Socially Assistive Robotics in Care for Elderly, a Systematic Review. Human-Robot Personal Relationships 2011;59:83-89.

Cremers G, Gelderblom G), Bemelmans R. Wheelchair Simulator Selecting Optimal Wheelchair Control. Assistive Technology Research Series 2011;29:695-702.

Gelderblom G), Bemelmans R, Jonker P, de Witte L. Social robot interventions in psychogeriatric care. Gerontechnology 2012;11(2):284

Bemelmans R, de Witte L. A Pilot Study On The Feasibility of Paro Interventions In Intramural Care For Intellectual Disabled Clients. Published in the Proceedings of the New Friend 2015 conference on social robots in education and therapy. Almere, The Netherlands, October 2015. 